\title{
Pennsylvanian to Jurassic eolian transportation systems in the western United States
}

\author{
FRED PETERSON \\ U.S. Geological Survey, MS 939, Denver, CO 80225-0046 (U.S.A.) \\ (Received December 1, 1986; revised and accepted February 3, 1987)
}

\begin{abstract}
Peterson, F., 1988. Pennsylvanian to Jurassic eolian transportation systems in the western United States. In: G. Kocurek (Editor), Late Paleozoic and Mesozoic Eolian Deposits of the Western Interior of the United States. Sediment Geol., 56: 207-260.

The direction of sediment transport in eolian sandstones of Pennsylvanian to Jurassic age was interpreted from crossbedding resultants (vector means) obtained from studies of eolian rocks in the western U.S., supplemented by data from the few eolian units of eastern North America. These were compiled from the published or unpublished (theses) literature, from unpublished field data contributed by colleagues, or from measurements made for this study. In addition, new paleogeographic maps were compiled to evaluate the influence of geographic features on the atmospheric circulation patterns that are inferred from the crossbedding studies.

Regionally, the crossbedding indicates northeasterly, northerly, or northwesterly winds (present coordinates) from Pennsylvanian through most of Middle Jurassic time. A rather abrupt change in wind directions occurred in late Middle Jurassic time (late part of the Callovian Age) when westerly wind patterns developed. By the Late Jurassic the winds shifted to southwesterly.

Calculations of the consistency factor (vector mean strength) made from region-wide analyses of the resultants indicate fairly unidirectional winds from the Pennsylvanian through the Early Jurassic. Middle Jurassic circulation was more varied, judging from crossbedding studies in the lower part of the Entrada Sandstone. Crossbedding in Upper Jurassic eolian rocks of Wyoming and South Dakota yielded a random pattern but Upper Jurassic rocks farther south on the Colorado Plateau and adjoining areas show a return to a fairly unidirectional pattern.

Comparing the resultants with their reconstructed paleogeographic setting shows surprisingly little influence of major geographic features on overall circulation patterns. However, the greatest amount of local variation occurred at or near highly indented shorelines where the temperature contrast between land and water produces local wind currents that may vary appreciably from regional circulation patterns. Although they do not cause noticeable horizontal deflections in wind patterns, small and low topographic highs appear to be able to promote the development of a dune field if a source of sand is available and if streams do not enter the growing dune field.
\end{abstract}

\section{Introduction}

The abundant, widely distributed, and wellstudied eolian sandstones of Pennsylvanian, Permian, Triassic and Jurassic age in the western U.S. (Figs. 1-3) offer an opportunity to reconstruct near-surface wind patterns over broad areas during fairly narrow time intervals. In addition, sedimentologic, paleogeographic, paleomagnetic and paleotectonic studies have evolved sufficiently to reconstruct the distribution of environments reasonably well and to determine the latitudinal position of North America during this span of time. Thus, the wealth of information available from studies of these rocks allows one to approximately reconstruct ancient paleogeographies and regional wind patterns, to compare and contrast these patterns with predictions from theoreti- 


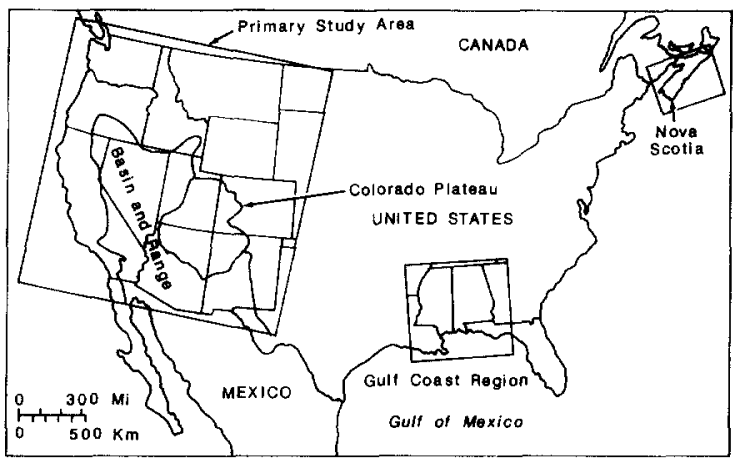

Fig. 1. Index map showing study areas. cal circulation models, and to postulate reasons for deviations.

The present study is primarily a compilation of data obtained from sedimentologic and crossbedding studies of Pennsylvanian-Jurassic eolian sandstones in the Western Interior of the United States (Fig. 3) that were made by numerous workers, cited in the appendix, or by me. Additional data were also gathered from the scarce eolianites in eastern North America (Fig. 1) for completeness and to compare them with theoretical circulation patterns in other parts of the continent. The eolian data are superimposed on new paleogeographic maps constructed from studies by me or other workers credited in the text. Interpre-

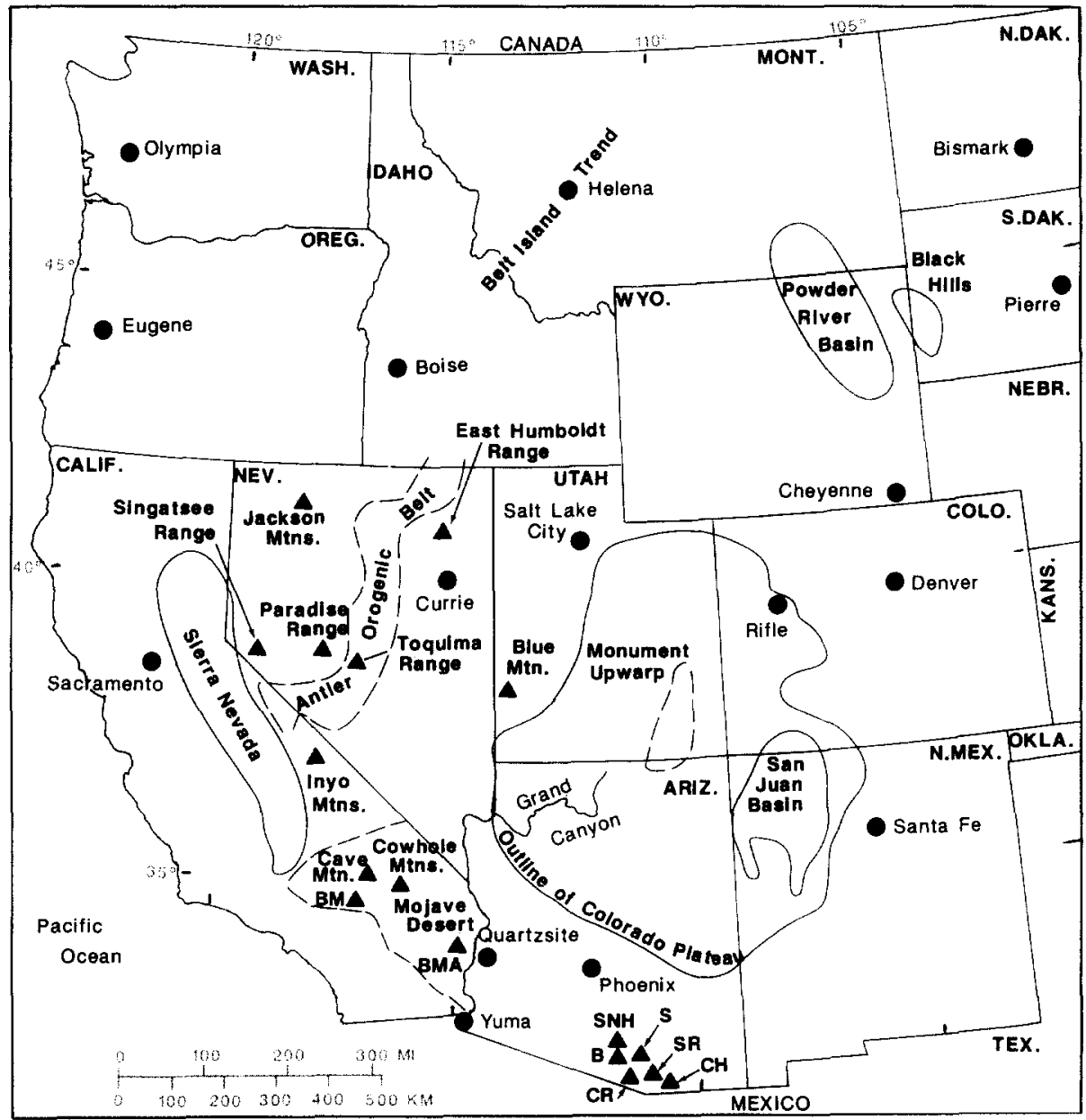

Fig. 2. Map showing localities in the western U.S. that are discussed in this report. $B=$ Baboquivari Mountains; $B M=B$ lack Mountain; $B M A=$ Big Maria Mountains; $C H=$ Canelo Hills; $C R=$ Cobre Ridge; $S=$ Sierrita Mountains; $S N H=$ Sil Nakya Hills; $S R=$ Santa Rita Mountains. 
tations in this paper are confined primarily to generalizations about the atmospheric circulation patterns, the relationship of the circulation patterns to geographic features, and interpretations of upwind source areas for the eolian deposits. Additional interpretations concerning the processes responsible for the circulation patterns are reserved for another paper (Parrish and Peterson, this volume) where the data can be evaluated in the context of global atmospheric circulation models.

\section{Methods}

Crossbedding dip vectors obtained from ancient eolian sandstones are here considered an excellent reflection of ground-level wind currents. Although there may be local deviations from the regional wind pattern (Rubin and Hunter, 1983; G. Kocurek, pers. commun., 1986), the consistency suggests that, in general, this is negligible when a fairly large number of measurements are made through as great a vertical sequence of strata as possible. Notable exceptions are the Middle Jurassic Entrada Sandstone and the Upper Jurassic Morrison Formation and related beds in central Wyoming and southwestern South Dakota. Measurements on second-order bedding surfaces seem to be the most reliable indicators of local wind patterns (Rubin and Hunter, 1983), but most measurements were taken on the dipping laminae within sets rather than on second-order bedding surfaces. In my work, I tried to obtain a dip-vector measurement from each set during traverses up or down the vertical dimension of any eolian unit, but this was not always possible and in some cases the measurements had to be obtained from walking randomly (as much as access would allow) over the outcrops. For the most part, random measurements throughout all or part of the eolian formations are what is mostly available in the literature, and a reevaluation based on more involved studies must, perforce, await future work.

Crossbedding resultants (also known as vector means) are measurements of central tendancy of the dip-vector measurements and were obtained from published reports, unpublished M.S. theses or Ph.D. dissertations, and unpublished data col- lected by me or by colleagues who kindly contributed them to this study. The data sources as well as the names of the stratigraphic units that contain the eolianites are given in the appendix. The methods of computing crossbed orientation data were developed by Reiche (1938) and later amplified by Curray (1956). The resultants are plotted on maps with the commonly used "tadpole" symbol in which the head is at the place of measurement and the tail leads away in the direction of the resultant. Resultants based on 10 or more measurements are shown on maps with tails of solid lines and with dashed lines in the few cases where they are based on 5-9 measurements (localities with fewer than 5 measurements were not used). In most cases where the number of measurements is given in a report, more than 15 measurements were made for each resultant; in my studies, 25 or more measurements were made if at all possible. The number of measurements was not given in some reports but a solid tail is used where the available information suggests that the number most likely was greater than 10 . For example, Tanner (1965) mentions that "more than 1000 cross-bed units were examined in the field" from which he obtained about 54 resultants. This suggests an average of about 18 measurements per resultant, which is considered a reasonable indication that each of his resultants was based on at least 10 measurements.

The consistency factor (also known as consistency ratio or vector mean strength) is a measure of the dispersion of the individual measurements and ranges between zero (totally random or, rarely, a "bow tie" distribution) and one (all measurements pointing in one direction). Resultants having consistency factors less than 0.20 were rare and were eliminated. In reports where the consistency factor was not given and could not be calculated, the resultant was used anyway, based on the assumption that the original author would have eliminated the resultant had the consistency factor or some other statistical test indicated that the resultant was not statistically sound or that the author would have alerted the reader to indications of inconsistency. In some cases, only rose diagrams or other types of diagrams were given without the computed resultants or consistency 


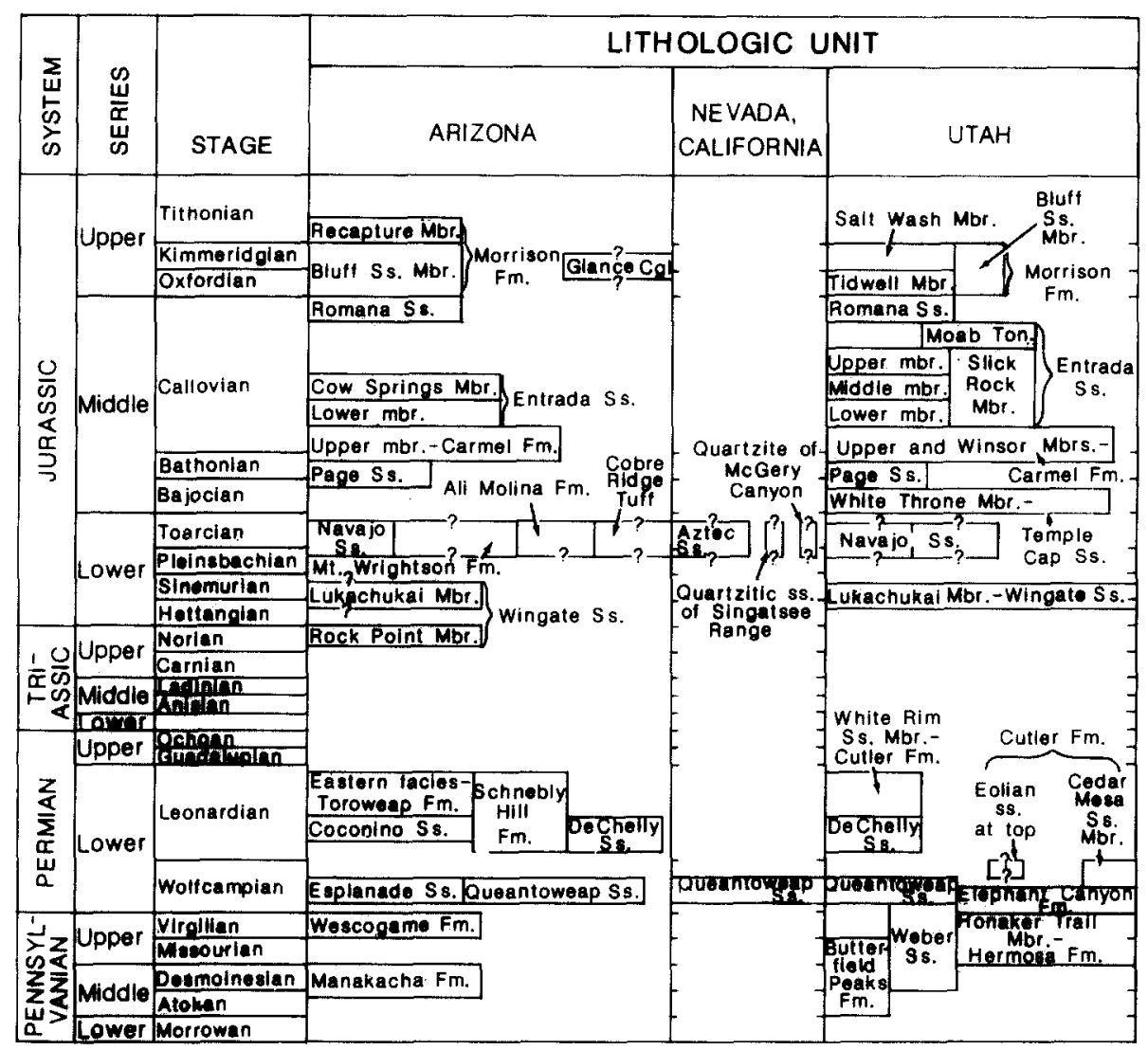

Fig. 3. Time-stratigraphic relationships of eolian sandstone units discussed in this report.

factors. For these, the diagrams were enlarged to a workable size, divided graphically, and the resultants and consistency factors were calculated as well as circumstances would allow.

In some aspects, rose diagrams can give a better understanding of the variability in the data than the distribution of individual resultants shown on a map. Hence, to facilitate interpretations, the resultants were also used to make one or more summary rose diagrams for each time interval. Summary resultants were calculated from the resultants in each of the time intervals studied and these are also included on the rose diagrams. The summary consistency factors accompanying the rose diagrams were obtained from calculating the summary resultants and are not averages of the consistency factors obtained from each locality. It is important to note, however, that statistical treatment of the data by rose diagrams and summary resultants may be an oversimplification that can be misleading, especially if considered to solely represent regional wind patterns without considering expected regional variations in atmospheric circulation (see Parrish and Peterson, this volume). Although rose diagrams and summary resultants are traditional ways of treating the data, they must be viewed with caution and only in conjunction with the mapped distribution of the data.

Paleogeographic reconstructions were made from an evaluation and synthesis of published reports, improved considerably by helpful comments from colleagues. Paleogeographic concepts for the westernmost part of the United States (especially the northwestern part) are in a state of flux because the location, nature, and extent of accreted terranes; the timing of their accretion with North America; and subsequent translations along the continental margin are poorly understood (Silberling et al., 1987). At this stage, any 


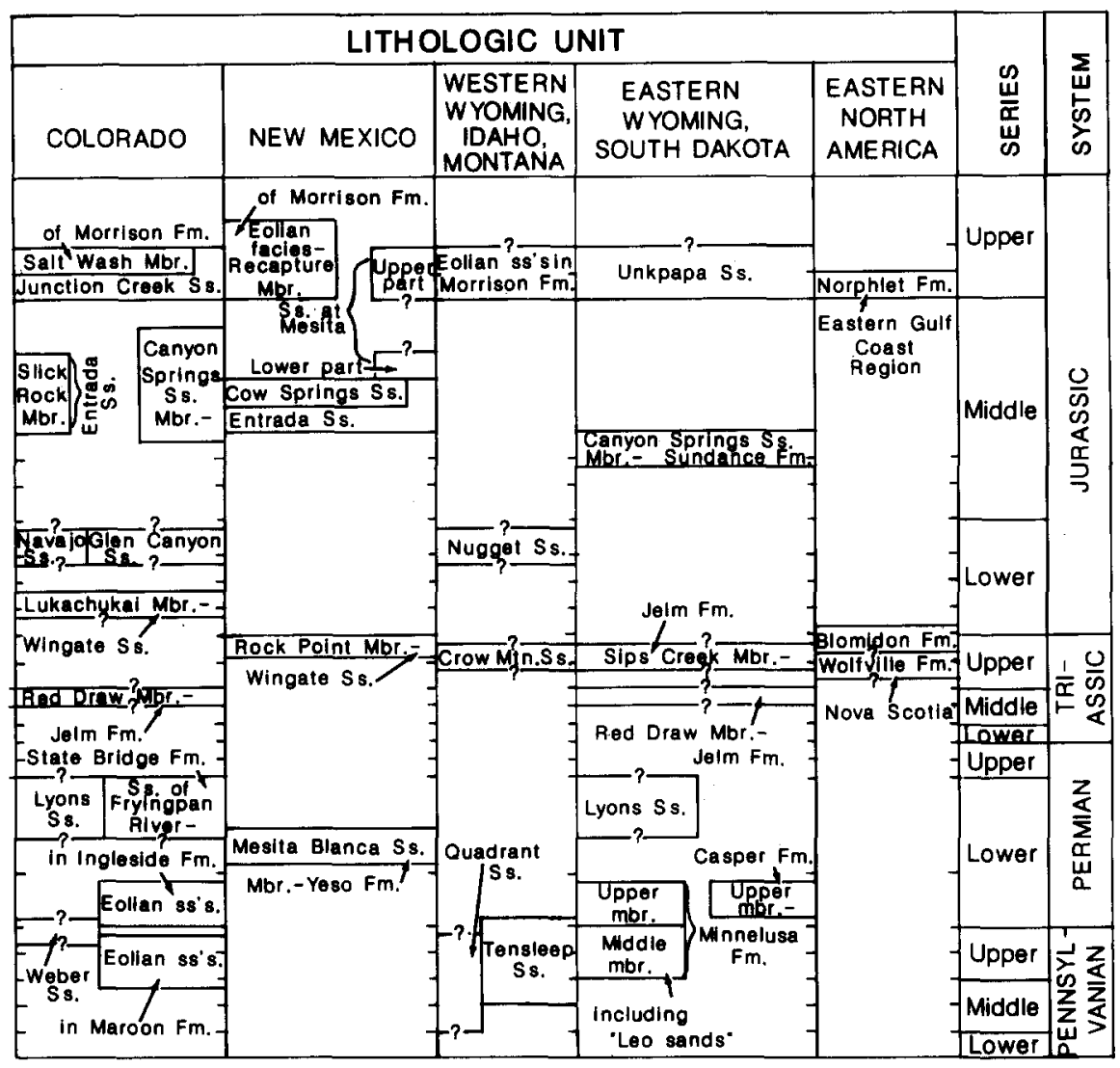

Fig. 3 (continued).

attempt to reassemble the complex westernmost part of the continent will be highly conjectural and certainly controversial. For this reason, restorations were omitted along the westernmost part of the continent.

Palinspastic corrections were not made in the Basin and Range region because of uncertainties about the amount of Mesozoic compression, Cenozoic extension, or the degree of translation along strike-slip faults. Paleogeographic reconstructions farther east in the Western Interior are more straightforward and are not complicated by excessive structural complexities. There, the reconstructions are especially helpful in providing an improved understanding of the causes of many of the local circulation anomalies.

In most cases, the crossbedding resultants are from beds that range through a greater time span than that represented by the paleogeography on the same map. In these cases, the paleogeography was modified as little as possible but sufficiently to accommodate the crossbed data and avoid showing resultants in non-eolian areas. Also, the maximum known or reasonably inferred extent of the eolian rocks is shown and the maps may not accurately reflect their distribution at any specific time, especially during the earlier and later parts of their existence. Thus, the paleogeographic maps are not truly such as they portray a generalization of the paleogeography for a time interval rather than the paleogeography for some instant in time.

Definitions of geomorphic terms that apply to the paleogeographic maps are necessary (Fig. 4). For purposes of this report, highlands are considered high hills or possibly mountainous areas with exposed bedrock that may have been source areas for large quantities of coarse material; their true height can only be inferred. Low hills are areas where bedrock (preexisting sedimentary rocks in most cases) was exposed, where only 
EXPLANATION FOR PALEOGEOGRAPHIC MAPS

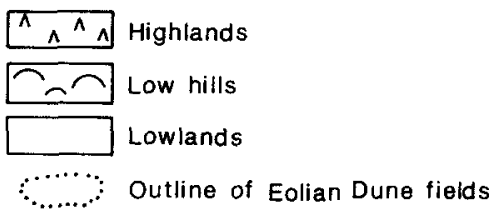

POSITIVE STRUCTURAL ELEMENTS

B Brazos uplift
BI Belt Island trend
BM Black Mesa uplift
C Chadion arch
D Defiance uplift
E Emery uplift
F Front Range uplift
M Matador arch
MR Milk River uplift
MT Monument uplift
P Pedernal uplift
PA Pathfinder uplift
PI Piute platform
S Sierra Grande uplift
SA Sawatch uplift
U Uncompahgre uplift
W Wyoming arch
Z Zuni uplift

Fig. 4. Explanation for paleogeographic maps.

fine-grained materials were shed onto adjacent lowlands, and where sediment accumulation was minimal. Bedrock includes any strata older than the time period under consideration, which may have been relatively unconsolidated and easily eroded materials. In places, the low hilly areas and even some of the highlands may include some eolian deposits, which is expected as wind can transport sand up rather appreciable slopes. Lowlands were continental areas that generally received sediment. The distribution of the eolian deposits is generalized, primarily from isopach studies elsewhere in this volume (Blakey et al., this volume) but also aided by localities known to include some eolian rocks (perhaps in incomplete sections) of the time period under consideration.

Several other conventions are used in this report. For consistency, all compass directions (even for paleowinds) are referred to present coordinates unless specifically stated otherwise. By standard usage, winds are referred to their source directions; thus, "westerly" winds flowed from west to east. Resultants were plotted on the maps with respect to the nearest full degree of longitude and the rose diagrams were then compiled from the resultants. Thus, the rose diagrams were constructed from resultants related to local north. Paleolatitudes are from Scotese (1979), Ziegler et al. (1983), and the Paleogeographic Atlas Project (1984). More recently, May and Butler (1986) revised Jurassic polar wander tracks for North America. Their work suggests that the continent may have been somewhat farther south during this period than is shown on maps in this report.

\section{Paleowinds}

Almost all of the major Phanerozoic eolian deposits of North America are of Pennsylvanian to Jurassic age and occur in the western United States. The only exceptions, to my knowledge, are eolian beds in Cambrian and Ordovician formations of the upper Mississippi Valley region (Dott et al., 1986), the Late Mississippian Darwin Sandstone Member of the Amsden Formation in western Wyoming (Houlik, 1973), the Upper Triassic Wolfville Formation and the Upper Triassic and Lower Jurassic Blomidon Formation of Nova Scotia, and the Upper Jurassic Norphlet Formation of the northeastern Gulf Coast region. The Norphlet and Wolfville Formations are included in this study but the others are not.

The climate at the site of deposition of most of these eolian deposits was warm and dry. The presence of extensive eolian beds as well as widespread evaporite deposits of anhydrite, gypsum, halite, and potash in other facies (McKee et al., 1956, 1959, 1967, 1975) suggests a generally dry environment for the Western Interior although it was not necessarily extremely dry, or wet and dry periods may have alternated seasonally. The presence of rare animal tracks and bones as well as petrified logs and root impressions in some of the eolian beds demonstrates that sufficient moisture was available, at least locally, to support some animals and vegetation. Other indications of the presence of moisture in one form or another in the dune fields represented by these beds include small conical features interpreted as fossil raindrop impressions and limestone or dolomite lenses interpreted as stromatolites or precipitates in small lakes or ponds within the dune fields. A warm 
environment is inferred from latitudinal position of the region at or near the equator and from global climatic studies (Nairn, 1961; Schwartzbach, 1963; Hallam, 1975).

In the Western Interior, the Triassic Period, especially the Late Triassic Epoch, appears to have been wetter than the Pennsylvanian, Permian and Jurassic. The Early Triassic of the Colorado Plateau probably was fairly dry (Blakey, 1974) but the presence of abundant aquatic plant and animal remains in the lower part of the Upper Triassic Chinle Formation (Ash, 1972; Gottesfeld, 1972) indicates that by early Late Triassic time the climate was wetter, at least seasonally (Dubiel, 1984, 1987, a, b, c; Parrish and Peterson, this volume). A wet climate probably accounts for the scarcity and small size of Triassic dune fields in the region. An upward increase in the quantity of red beds and eolian deposits in the Chinle Formation and correlative deposits led Blakey and Gubitosa (1984) to infer increasing aridity during the Late Triassic.

\section{Pennsylvanian to earliest Wolfcampian time}

The oldest eolian deposits in the Western Interior that are included in this study are of Middle Pennsylvanian (Desmoinesian) to earliest Permian (earliest Wolfcampian) age (Fig. 3). These deposits include the Quadrant Sandstone of southwestern Montana, the Tensleep Sandstone in central Wyoming, eolian beds including the "Leo sands" in the middle member of the Minnelusa Formation of eastern Wyoming and southwestern South Dakota, eolianites in the Butterfield Peaks Formation of north-central Utah, the Weber Sandstone of northeastern Utah and northwestern Colorado, eolian sandstones recently identified by Johnson (1987ab) in the Maroon Formation of west-central Colorado, several eolian beds in the Honaker Trail Member of the Hermosa Formation and in the Elephant Canyon Formation (the "Rico" Formation of Loope, 1981, 1984) in southeastern Utah, and eolian strata in the Manakacha and Wescogame Formations of the Supai Group in the western Grand Canyon.

Several of the eolianites range from Pennsylvanian into the Wolfcampian and are included here rather than with other but strictly Wolfcampian eolianites because of uncertainties about their ages within the Pennsylvanian-Wolfcampian time interval. E.K. Maughan (pers. commun., 1987) suggests that an unconformity may separate the Pennsylvanian and Wolfcampian parts of these eolian complexes but, in most cases, an unconformable surface is difficult to identify within an unfossiliferous and largely or partly eolian sandstone interval. Moreover, crossbedding measurements were obtained from the entire eolian sandstone interval and a distinction between Pennsylvanian and Wolfcampian parts was not made by the various workers.

\section{Paleogeography}

The regional paleogeography of the Western Interior during Middle Pennsylvanian to earliest Wolfcampian time is of a broad and highly irregular peninsular area extending southward (present coordinates) from western Canada to the Mexican border (Fig. 5). During times of high sea levels, the extent of land on the peninsula would have been considerably diminished and the southern part may have been a large island. The large Midcontinent sea covered much of the central United States, extending hundreds of kilometers east of the peninsula and occasionally reaching into New York and Pennsylvania (Heckel, 1980). The continent was appreciably farther south than now such that the Equator trended northeast across the southeastern part of the study area.

Highlands that were the source of large volumes of coarse detritus lay in several areas, primarily in the ancestral Front Range and Uncompahgre uplifts in Colorado, eastern Utah, and north-central New Mexico; the Sierra Grande uplift of northeastern New Mexico; and the Pedernal uplift in New Mexico (Peterson and Hite, 1969; Mallory, 1972; Sutherland, 1972; Casey, 1980; De Voto, 1980). Although it is not possible to determine the height of these features, a pervasive thought among geologists working on the coarse detritus shed from these ranges is that they would have qualified as mountains or high ridges that reached one or perhaps several thousand meters above sea level. Low hilly areas that supplied moderate quantities of sand and clay were scattered about 


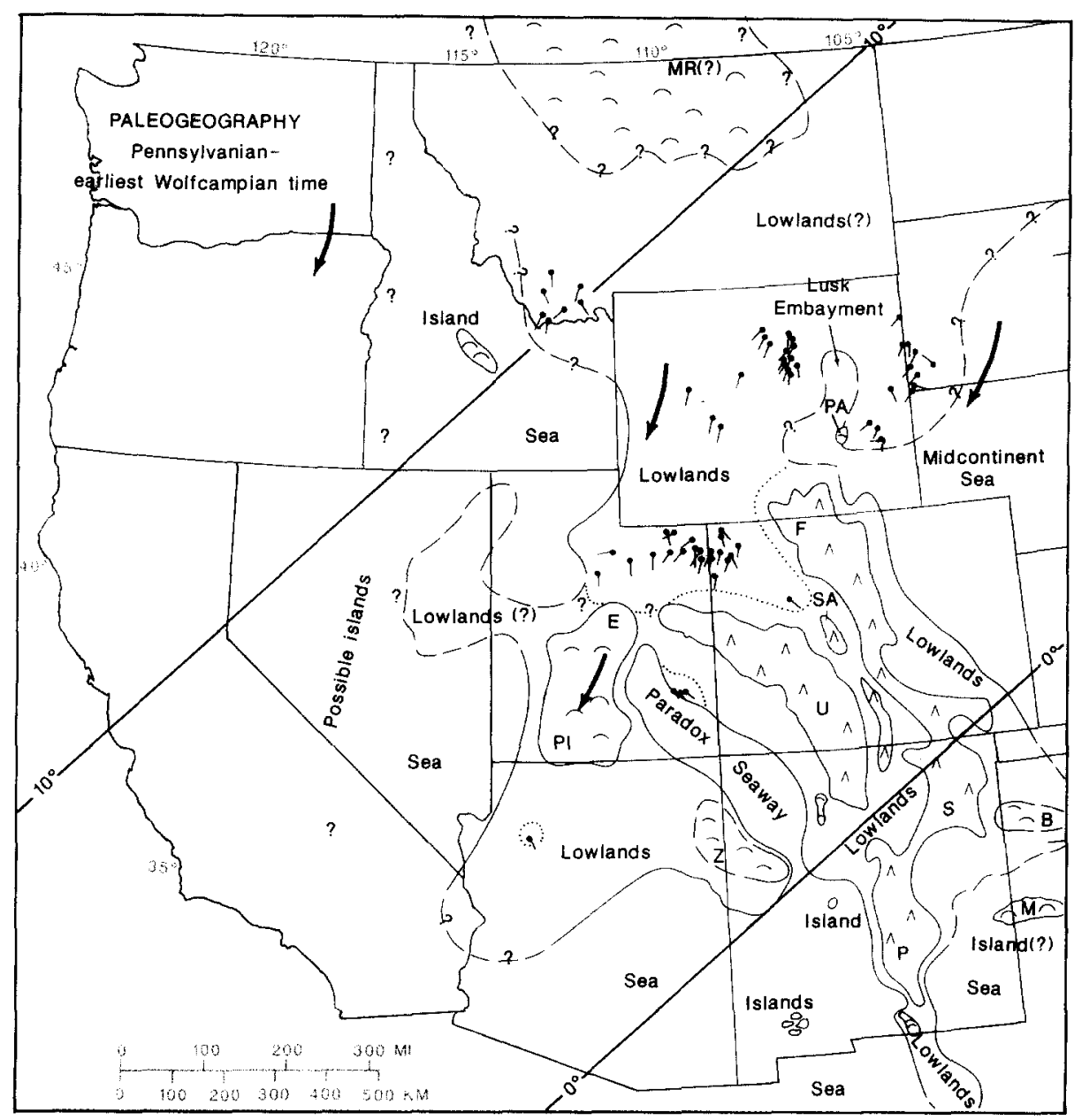

Fig. 5. Paleogeographic map for Pennsylvanian to earliest Wolfcampian time showing crossbedding resultants and paleolatitudes. The paleogeography is mainly for the Late Pennsylvanian (Virgillian Age). Large arrows indicate predicted wind patterns from Parrish and Peterson (this volume).

the southern part of the region (Mallory, 1972; Kottlowski, 1985) and a broad area of low hills called the Milk River uplift lay farther north in north-central Montana (Maughan, 1975).

Small island areas have been documented in several places around the periphery of the region and undoubtedly more existed. Skipp and Hall (1980) show the Copper Basin highland as a fairly large island in east-central Idaho. Pajarito island in central New Mexico (Kelley, 1971) and the Florida islands in the southwestern part of the same state (Clemons, 1980) lay on a shallow marine shelf. The Matador arch in southeastern New Mexico and adjacent parts of Texas also may have been expressed as an island (McKee et al., 1975, pl. 15-C). Paleogeographic reconstructions in Nevada and California by Rich (1977) suggest that the Antler orogenic belt was the site of a long island off the west coast of the peninsula.

The mainland shoreline is difficult to identify in much of the southern part of the region where, apparently, it lay close to several positive areas such as the Pedernal uplift that extended southward across the middle of New Mexico (Mallory, 1972; Kottlowski, 1975; McKee et al., 1975; Siemers, 1983). The shoreline can be located fairly well in the north-central part of New Mexico where a deltaic complex has been identified by Kues and Kietzke (1976). The shoreline is reasonably well defined in the eastern part of the 
state and in adjacent parts of Texas through studies by Meyer (1966), Wermund and Jenkins (1969), and Handford and Dutton (1980).

The trend of the shoreline in northern Arizona is from Blakey (1980) but it could not be defined well in the west-central part of the state and adjoining parts of California where lack of sedimentologic study or severe metamorphism hinder paleogeographic reconstructions. Continuity of the shorelines as far south as indicated on the map is based on recognition of Pennsylvanian strata similar to that of the Grand Canyon section in the Big Maria Mountains and nearby ranges of California (Hamilton, 1982) and in the vicinity of Quartzsite, Arizona (Reynolds, 1980). An irregular extension of land is thought to have existed in west-central and northwestern Utah and northeastern Nevada (Rich, 1977; Jordan and Douglas, 1980). Some reconstructions, perhaps outdated now and not shown on Fig. 5, connected this extension with a linear emergent area on part of the Antler orogenic belt that stretched north-northeastward across central Nevada (McKee et al., 1975, pl. 15-C; Rich, 1977).

Two marine embayments - the Lusk embayment and the Paradox seaway-extended well into the peninsula and, in various ways, influenced the distribution of nearby depositional environments. The Lusk embayment was a small arm of the Midcontinent sea that extended into eastern Wyoming (Desmond et al., 1984). Judging from the distribution of facies in the Minnelusa Formation of southeastern Wyoming (Desmond et al., 1984), the embayment existed during eustatic sealevel lowstands although it may have been much smaller than indicated (Fig. 5). It is also conceivable that the interpretation of an embayment is a product of greater solution of Minnelusa evaporites in the Black Hills region farther east with a resulting increase in percentages of eolian sandstone there compared to the subsurface area in eastern Wyoming (E.K. Maughan, pers. commun., 1987). Studies by Agatston (1954) help to define the southwestern shoreline of this embayment.

The Paradox seaway farther south was a highly restricted marine embayment where large quantities of gypsum, halite, and potash minerals pre- cipitated in Middle Pennsylvanian time (Wengerd and Matheny, 1958; Hite and Cater, 1972). The location of the outlet is not known with certainty but current thought is that it was in northwestern New Mexico as indicated on the map (Fig. 5; R.J. Hite, pers. commun., 1987). The Paradox seaway extended far inland and nearly isolated the lowland area in southwestern Utah and Arizona from the main mass of the peninsular area farther north and east, especially during sea-level highstands.

Eolian dune fields covered fairly large areas in the northern part of the Western Interior peninsula during the Middle and Late Pennsylvanian. The size of the dune fields (or ergs) is somewhat exaggerated on the map (Fig. 5) because the various eolian units are not all of the same exact age, because many of them expanded and contracted considerably with migrations of shorelines during glacioeustatic sea-level changes, and because the greatest known areal extent of the eolian deposits is shown on the map. Eolian sandstone units in southeastern Utah and northern Arizona have not been studied adequately and little is known about their areal extent, although reconnaissance studies suggest that scattered eolian deposits cover significantly larger areas than is shown on the map.

The origin of crossbedded sandstone beds in the Manakacha and Wescogami Formations of northwestern Arizona is not clear, partly because unequivocal evidence was not found in these units and partly because the formations are in need of thorough sedimentological examination. McKee (1982, p. 261) considered these beds marine, estuarine, and fluvial deposits. However, another interpretation that is gradually becoming accepted is that at least some of these deposits are eolian, as suggested by their excellent sorting and considerable set thicknesses (as much as $10 \mathrm{~m}$ according to McKee, 1982, p. 216). Definitive sedimentologic criteria such as sand-flow toes and wind-ripple laminae were not found where reconnaissance studies were made in the western Grand Canyon, but unequivocal criteria of marine, estuarine, or fluvial deposition likewise were not found in these beds.

\section{Paleowinds}

The regional pattern of atmospheric circulation 


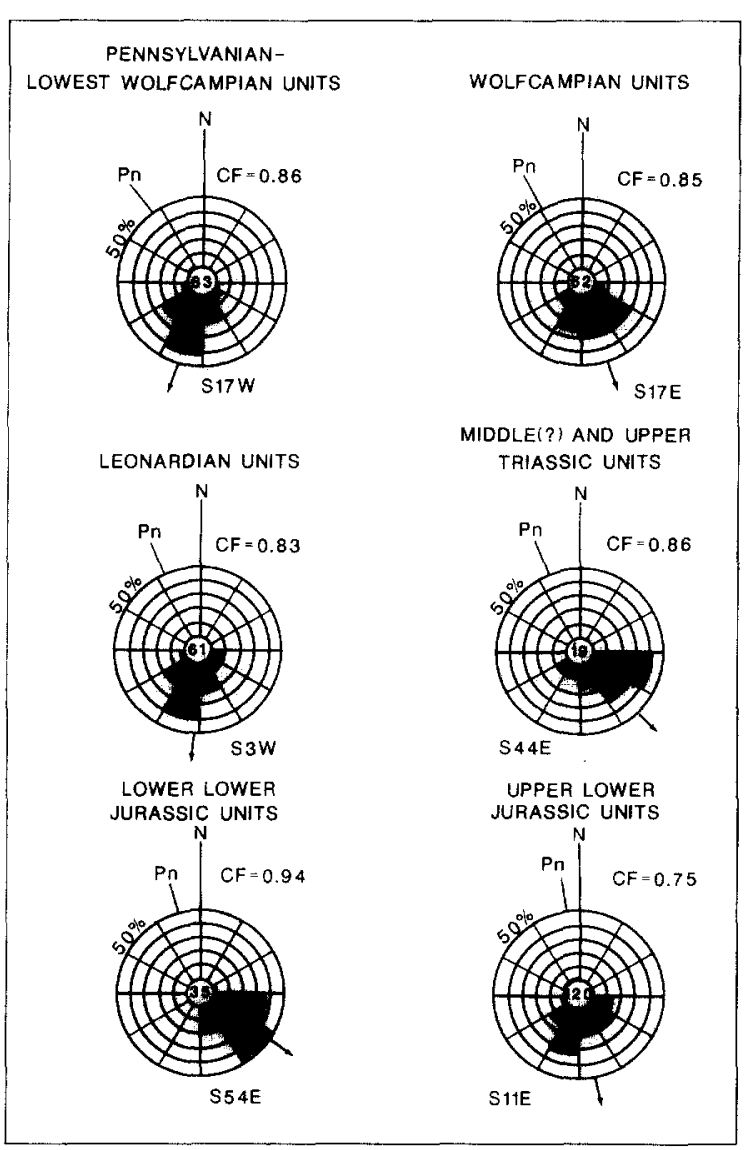

Fig. 6. Rose diagrams of Pennsylvanian to Lower Jurassic crossbedding resultants. The number of resultants used is given in the center and the arrow and bearing are of the summary resultant. $\quad N=$ present north; $P n=$ paleonorth; $C F=$ consistency factor.

for Late Pennsylvanian to earliest Wolfcampian time, as determined from statistical treatment of the resultants, is of north-northeasterly winds (Fig. 6). In terms of paleocoordinates, these would have been northeasterly winds. Statistical treatment of the 63 resultants shown on the map yielded a fairly high consistency factor of 0.86 , indicating little variation to the overall data set. Although it is not as clear as on other maps, a northeastwardtrending line that passes through the southwestern corner of Utah divides the resultants into two fields. Thus, the geographic distribution to the data suggests north-northeasterly winds in the area northwest of this line and northwesterly winds in the area southeast of the same line.
The one locality in northwestern Arizona that was examined for this study yielded a resultant pointing to the south-southeast. Crossbedding studies made in these formations by McKee (1982) but over a larger area yielded essentially the same directions as the single resultant of this study but they are not included here as it is not clear whether they came from what would now be considered eolian deposits or from strata deposited in other environments.

The greatest amount of local variation is on the east side of the Lusk embayment in eastern Wyoming and southwestern South Dakota where they are associated with a highly embayed shoreline. The data on the east side of the embayment is largely from subsurface dipmeter surveys. Thus, the fairly high degree of variability could reflect measurements in shallow marine crossbedded sandstones, perhaps reworked from the eolian deposits, that were inadvertently considered eolian.

The influence of major orographic features on circulation patterns is not clear from the available data (Fig. 5). The southeasternmost resultants in northwestern Colorado and southeastern Utah dip to the southeast, in contrast to the southsouthwestward regional trend (Fig. 6). The location of these resultants downwind from major orographic features-the Front Range and Uncompahgre uplifts - suggests counterclockwise deflection of the winds around the northwestern tips of these highland areas. However, the single resultant in northwestern Arizona also dips to the southeast and no major orographic features are nearby other than the Piute platform more than $100 \mathrm{~km}$ to the north. If this single resultant is a reliable guide to the circulation patterns, it suggests that the southeastward-dipping crossbedding is a function of expected regional circulation patterns (see Parrish and Peterson, this volume) rather than of systematic deflections around topographic highs. Crossbedding in probable eolian strata east and west of this locality in the Grand Canyon dip in similar directions (McKee, 1982), indicating that the single resultant obtained from northwestern Arizona for these studies most likely is a reliable indicator of circulation patterns for this area. 


\section{Source areas}

The crossbedding indicates that most of the eolian sand in the northern part of the region came from the north, probably from eroded older beds in the Milk River uplift of north-central Montana and adjacent parts of Canada, or from lowland areas farther east. Thin beds here interpreted as eolian deposits are interbedded with marine, tidal flat, and sabkha deposits in northwestern Arizona but they have not been adequately studied. The single resultant is not much help in pinpointing the source area, which could have been from the shoreline in northwestern Arizona and southwestern Utah, eroded beds on the Piute platform in southwestern Utah, or simply from reworking of exposed marine sands dur- ing low stands of sea level. Eolian beds in the Maroon Formation of west-central Colorado probably received their sediment locally from the beds of streams that flowed off the ancestral Front Range and Uncompahgre highlands nearby although some or a large part of it could have come from the large Quadrant-Tensleep-Weber erg farther north. Small dunefields in southeastern Utah most likely originated by reworking of marine sands during eustatic low stands of sea level.

\section{Wolfcampian time}

Eolian strata of Wolfcampian age other than earliest Wolfcampian units included in the previ-

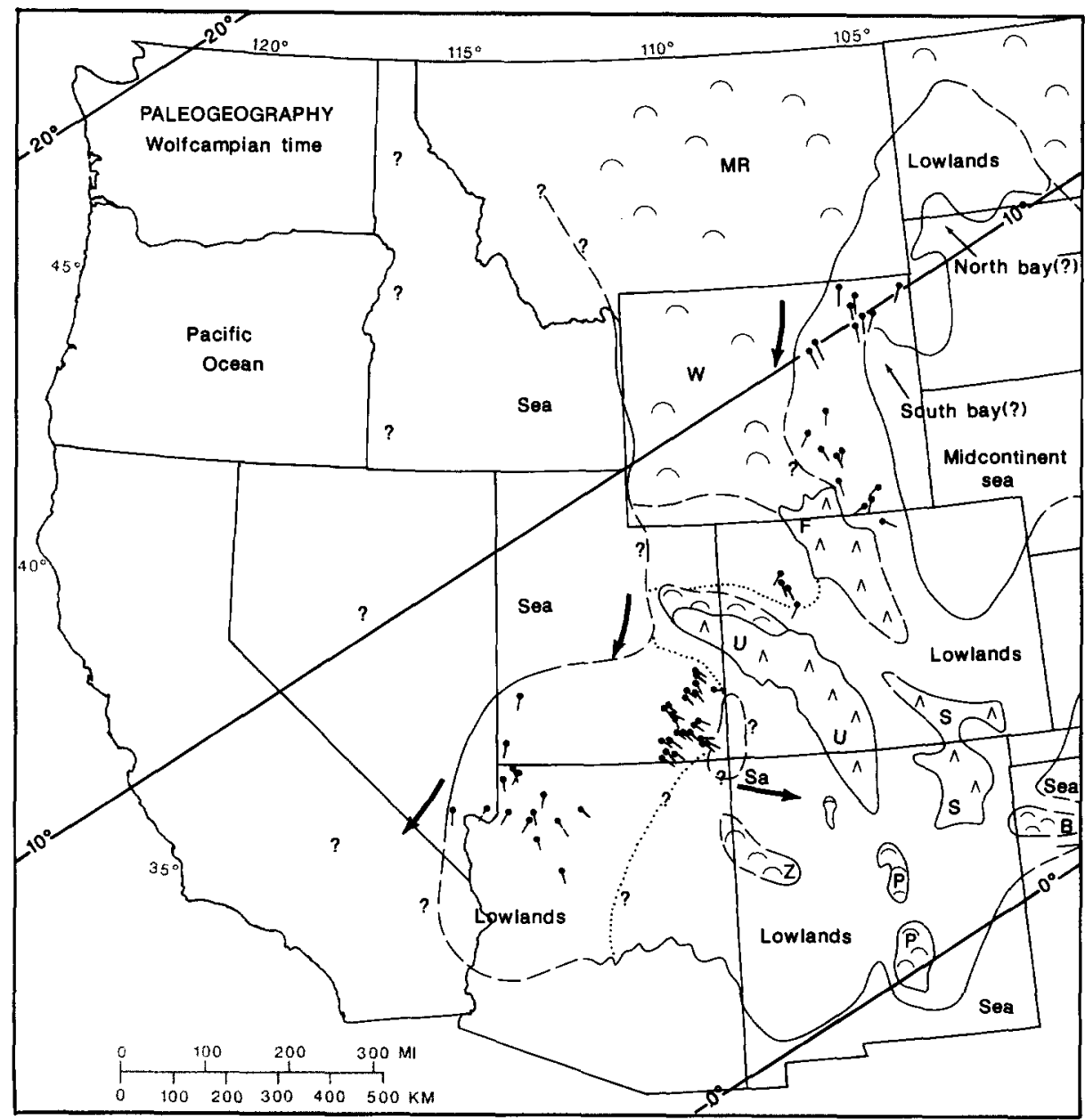

Fig. 7. Paleogeographic map for Wolfcampian time showing crossbedding resultants and paleolatitudes. Large arrows indicate predicted wind patterns from Parrish and Peterson (this volume). $S a=$ Inland sabkha. 
ous discussion lie in a long belt that stretches northeastward across the Western Interior (Fig. 7). One of the ergs is represented by the upper member of the Minnelusa Formation in northeastern Wyoming, the upper member of the Casper Formation in southeastern Wyoming, and a few eolian beds in the Ingleside Formation in north-central Colorado, which may have been physically connected to the main mass of the erg farther north (Fig. 7). Eolian beds in northwestern Colorado assigned to the Schoolhouse Tongue of the Weber Sandstone may also be part of the same erg system or they might be younger and of Leonardian age (E.K. Maughan, pers. commun., 1987). In southeastern Utah, the Cedar Mesa Sandstone Member of the Cutler Formation and an unnamed eolian bed at the top of the Cutler that is locally exposed in the core of an anticline, constitute another fairly extensive area that was largely covered by dunes. The Esplanade Sandstone of the Supai Group in northwestern Arizona and the Queantoweap Sandstone (of McNair, 1951) in southern Nevada, southwestern Utah, and the northwesternmost corner of Arizona are now thought to be largely eolian (Johanson, 1981).

\section{Paleogeography}

The paleogeographic setting of the Western Interior during Wolfcampian time was similar to that of the Pennsylvanian. A highly irregular peninsula extended south across the Western Interior almost to the Mexican border, separating waters of the ancient Pacific Ocean from the Midcontinent sea farther east (Fig. 7). Latitudinally, the continent had not migrated any significant distance since Pennsylvanian time and the Equator still lay in the southeastern portion of the study area. As with the Pennsylvanian, large quantities of sediment were being moved about by shallow marine, eolian and fluvial processes, producing broad lowlands that extended appreciable distances away from highlands and low hilly areas.

Highlands or possibly mountainous areas, primarily in Colorado and New Mexico, still dominated the topography of the region. The Uncompahgre and Front Range highlands remained from earlier times as the backbone of the peninsula and continued to provide large quantities of coarse detritus (sand and gravel, including large boulder-size materials) to surrounding lowlands (Rascoe and Baars, 1972; Fryberger and Koelmel, 1986, fig. 4). Scattered positive elements in the southern part of the region also were sources of clastic materials although generally not as coarse and certainly not as Voluminous as that shed from the Uncompahgre and Front Range highlands (McKee et al., 1967; Hunt, 1983; Kottlowski, 1985; Fly, 1986). A broad positive area named the Milk River uplift lay in Montana and adjacent parts of Canada (Maughan, 1975) and, through the Wyoming arch, connected with the Front Range highlands (E.K. Maughan, pers. commun., 1987).

Reconstructions by Stevens (1977) indicate a volcanic island complex offshore in the Pacific, but its extent and location are too poorly constrained to merit inclusion on the paleogeographic map.

In general, the Wolfcampian shoreline was not as deeply intended as it was during the Pennsylvanian, although to some extent this could be a function of lack of detailed studies. With some qualifications, no large embayments similar to those of earlier times are known in the peninsular area.

A fairly large oval area containing bedded gypsum lies just east of the Cedar Mesa Sandstone Member of the Cutler Formation and extends more or less north from the Four Corners. This may have been a saline lake or inland sabkha completely isolated from the sea (as shown on Fig. 7) or it may have been connected somehow to the ocean. Baars (1987) suggests a connection with marine waters farther northwest between the Cedar Mesa dune field and the Uncompahgre highlands. In contrast, J.A. Campbell (pers. commun., 1987) favors a southern connection, perhaps following that of the earlier Paradox seaway through northwestern New Mexico. Because it is not possible to reconcile the different views of Baars (1987) and Campbell (1987), an alternative and equally viable approach was used in which the gypsiferous area is shown as an inland sabkha without a direct connection to the ocean.

Several embayments from the Midcontinent sea are hypothesized to have indented the shoreline from eastern Wyoming to South Dakota (Rascoe 
and Baars, 1972; Fryberger, 1984), although this interpretation may be more apparent than real. As noted for Pennsylvanian rocks of this area, it may be related to later dissolution of evaporite minerals with an attendant increase in sandstone percentages in outcrop areas in the Black Hills where dissolution occurred. Interpreting shoreline trends from sandstone percentages could, therefore, yield an interpretation of an embayment farther west that merely reflects less solution of evaporite minerals in underground areas (E.K. Maughan, pers. commun., 1987). Nevertheless, detailed studies of marine dolomites interbedded with eolian sandstones of the Minnelusa Formation in this area indicate numerous embayments and a highly irregular shoreline (Achauer, 1987).

Paleogeographic studies by McKee et al. (1967) show the Milk River uplift projecting southward across Montana and into Wyoming, with the western shoreline in the western parts of both states.

Recognition of eolian deposits in the Queantoweap Sandstone and correlative units of southeastern Nevada, northwestern Arizona (Esplanade Sandstone, Sandstone of Virgin Gorge of Steed, 1980), and southwestern Utah (Blakey, 1979; Johanson, 1981) demands a shoreline west of those deposits, presumably extending northeastward from southeastern Nevada and along the western margin of the Piute platform, which may have been slightly positive in Wolfcampian time. Eolian deposits in this area that are best considered part of the Queantoweap occur at least as far north as Blue Mountain (northernmost resultant in southwestern Utah on Fig. 7) where they have been consistently misidentified as the Middle Jurassic Carmel Formation (Miller, 1966; Weaver, 1980). The presence of eolian sandstones at outcrops this far north, and subsurface continuation of the same sandstones farther northeast (Rascoe and Baars, 1972) suggest that the shoreline extended northeastward approximately as shown on the map rather than southeastward into a fairly large embayment in southeastern Utah as suggested by Hallgarth (1967). However, the shoreline probably migrated back and forth in this region as well as in other areas in response to sea-level oscillations, as suggested by Mack (1977). Studies by Blakey (1980), Peterson (1980), Hunt (1983) and Mack and James (1986) indicate that the shoreline trended irregularly eastward across southern Arizona and New Mexico into west Texas.

Several dune fields were scattered about lowland areas during Wolfcampian time (Fig. 7). In the northeastern part of the region, a fairly long and narrow erg extended southward from western North Dakota across eastern Wyoming into north-central Colorado. It may also have extended into northwestern Colorado and northeastern Utah although a physical connection between these two dune fields remains unclear. Farther southwest, another fairly extensive dunefield lay along the western shoreline of the peninsula. Exposures of the eolian strata in this part of the region are discontinuous but continuity of the sand sheet is apparent from its surface and subsurface distribution (McKee et al., 1967). The dunefields on either side of the Uncompahgre uplift may have been connected along a narrow passageway northwest of the uplift but the area is in a structurally deep part of the Uinta basin where subsurface information is lacking.

\section{Paleowinds}

For the Wolfcampian Age, the overall circulation pattern reflected in the crossbedding is of north-northwesterly winds with respect to present coordinates or north-northeasterly winds with respect to paleocoordinates (Fig. 6). When treated statistically, the data set has a fairly high consistency factor of 0.85 and a rather symmetrical and unimodal distribution on a rose diagram. Although not apparent from the rose diagram, the geographic distribution suggests division of the resultants into two fields separated by a line trending northeastward from the southern tip of Nevada. Resultants northwest of this line point approximately southward and resultants southeast of this line point approximately southeastward.

A small area of moderate variability is in a narrow coastal strip in southeastern Wyoming and adjacent Colorado where the ancestral Front Range highlands lay close to the Midcontinent sea. Whether the variability is related to the influence of the nearby highlands, sea, or both is undetermined. The eastern part of the dune field 
in northwestern Arizona has resultants dipping southeastward, suggesting a closer relationship, in terms of wind patterns, to the dune field in southeastern Utah than with adjacent parts of the dune field farther northwest.

The relationship of circulation patterns to major orographic features is somewhat clearer for the Wolfcampian than for earlier times because of the greater distribution of data. As with the Pennsylvanian to earliest Wolfcampian data, resultants just downwind from the Front Range and Uncompahgre highlands tend to be rotated counterclockwise from the regional south-southwestward trend (Fig. 7). However, the fair abundance of data in northwestern Arizona also shows a tendency for southeastward directed resultants that apparently are not related to any upwind topographically high feature. Thus, it would appear that systematic deflection of the winds by the highlands is questionable.

\section{Source areas}

The upwind source of the eolian sand in eastern Wyoming, northern Colorado, and northeastern Utah was from areas in the Milk River uplift of Montana and adjoining areas farther east (Fig. 7), perhaps redistributed some at the strandline of the Midcontinent sea that lay farther east. The dune field that stretched from southeastern Utah to northwestern Arizona and adjacent areas must have received its sediment from the nearby shoreline. The ultimate source for some of the sand in this dune field may have been from the beds of streams that flowed westward off the northwestern part of the Uncompahgre highlands but the drainage area appears too small to have contributed any significant amount of sediment. The long trend of eolian sand from southwestern North Dakota to northeastern Utah allows the possibility that sand from this dune field was carried to the western shoreline where it was redistributed by nearshore currents and subsequently blown inland to form the southern erg. The quantity of sand derived from the west side of the Milk River uplift and carried south along the shoreline to feed the southern erg is unknown but could have been substantial and may well have been the primary source of sand in the southern dune field.

\section{Leonardian time}

Eolian sandstones of Leonardian age in the Western Interior are included in the Lyons Sandstone of north-central Colorado and a small adjoining part of Wyoming, the sandstone of Fryingpan River in the State Bridge Formation (or the Maroon Formation; Johnson, 1987b) of west-central Colorado, the White Rim Sandstone Member of the Cutler Formation in southeastern Utah, the De Chelly Sandstone of southeasternmost Utah and northeastern Arizona, the Meseta Blanca Sandstone Member of the Yeso Formation in northwestern New Mexico, the Coconino Sandstone of northwestern Arizona, the eastern facies of the Toroweap Formation and Schnebly Hill Formation in north-central Arizona, and strata called the Coconino Sandstone in east-central Arizona that include equivalents of the Coconino as well as the eastern Toroweap Formation farther northwest (Fig. 3). As shown better by Blakey (this volume) and Blakey et al. (this volume), these are not all correlative and none extend through the entire age.

\section{Paleogeography}

The Western Interior landmass was dissected by irregular arms of the sea that extended across Wyoming and parts of Arizona, New Mexico and west Texas (Fig. 8). Although not apparent because of the limited size of the study area, the southern part of the region was a large island during part of the Leonardian, with normal marine waters to the north, west, and south and highly restricted marine environments to the east where evaporite deposits of halite, anhydrite, and gypsum precipitated from time to time (McKee et al., 1967; Rascoe and Baars, 1972). A series of islands of unknown distribution may have existed in the area that is now Nevada and California, and perhaps farther north (Stevens, 1977). The continent had migrated northward from earlier times and the Equator lay just off the southeastern corner of the study area.

In the northern part of the region, the Milk River uplift continued as an area of low hills, but it appears to have been cut off from the southern part of the region during most if not all of 


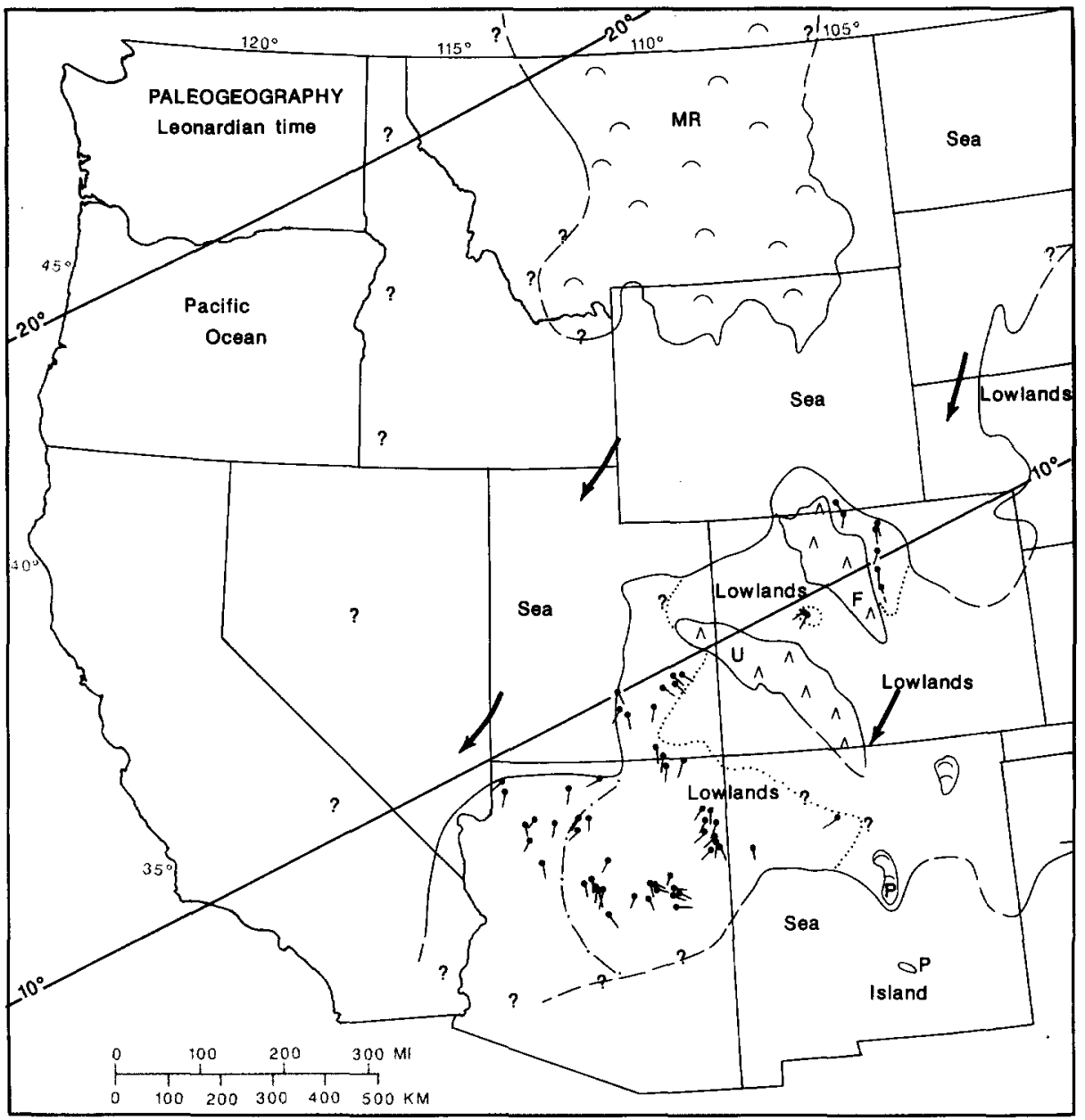

Fig. 8. Paleogeographic map for Leonardian time showing crossbedding resultants and paleolatitudes. Dot-dash line is latest Leonardian shoreline during deposition of the Toroweap Formation. Large arrows indicate predicted wind patterns from Parrish and Peterson (this volume).

Leonardian time. The western shoreline of the northern part lay in the same approximate position as before but the eastern side of the uplift was bordered by shallow marine waters rather than lowlands (Maughan, 1966; McKee et al., 1967; Skipp and Hall, 1980).

The Uncompahgre and Front Range highlands still dominated the topography in the southern part of the region although their heights, as suggested by the quantity of fine-grained debris shed from them, were more subdued than before. The shoreline in Utah and northwestern Arizona probably was less indented than what is shown on the map (Fig. 8), which was drawn to accommodate eolian deposits of slightly different ages within the
Leonardian. Thus, the shorelines during deposition of the Coconino Sandstone (older, in northwestern Arizona) and the White Rim Sandstone Member of the Cutler Formation and correlative rocks (younger, in southeastern Utah) and northcentral Arizona had appreciably different orientations. The Coconino thins northward to a wedgeedge near the Utah border (Baars, 1962; Phoenix, 1963) and westward near Las Vegas, Nevada (Bissell, 1969); its maximum known extent serves to define the position of the strandline indicated on the map (Blakey et al., this volume). The shoreline along the west side of the White Rim Sandstone Member of the Cutler Formation in Utah (Hallgarth, 1967; Baars, 1987) extended south across 
north-central Arizona to the eastern Grand Canyon region where equivalents are called the eastern facies of the Toroweap Formation (Rawson and Turner, 1979). Farther east in east-central Arizona, eolian equivalents of the Toroweap Formation are indistinguishable from eolian beds in the underlying Coconino and, for historical reasons, the undivided eolian unit is called the Coconino Sandstone (Reiche, 1938). The shoreline could not be located with any degree of confidence in the southern part of the Arizona-California area. The area shown as land, however, includes areas reported to contain Coconino Sandstone or the metamorphosed equivalent, the Coconino Quartzite (Stone et al., 1983). Shorelines farther east in Arizona, New Mexico, and west Texas are based on studies by McKee et al. (1967), Rascoe and Baars (1972), Blakey (1980), Handford and Fredericks (1980), and Kottlowski (1985).

Dune fields existed throughout much of the southern part of the region, but the large area southwest of the Uncompahgre highlands that is underlain by Leonardian eolian rocks (Fig. 8) is deceiving because no erg that large existed at any one time during the age. A better idea of the distribution of the various ergs is shown by Blakey et al. (this volume) who divide the age into three parts and show the distribution of the ergs in terms of smaller time segments. A small dune field represented by the Lyons Sandstone lay in the narrow coastal strip between the ancestral Front Range and an arm of the seaway farther northeast. Freeman and Bryant (1977) described eolian strata in the State Bridge Formation of westcentral Colorado that were deposited in a small dune field sandwiched between the Uncompahgre and Front Range highlands.

\section{Paleowinds}

Crossbedding studies indicate that the regional circulation pattern was of northerly winds with about as much variation as occurred during earlier times (Fig. 6). In terms of paleocoordinates, these were north-northeasterly winds. A fairly high consistency factor of 0.83 is similar to that obtained from older rocks in this study. The greater part of the variation seems related to proximity of most of the dunefields to the ocean but orographic effects may also have played a role. Some of the scatter of the resultants may be exaggerated because eolian strata of slightly different ages within the Leonardian were included on the same map. The largest amount of scatter is in the ergs of northern Arizona, northwestern New Mexico and southeastern Utah. This was a lowland area bordered on three sides by marine waters and on the fourth side by the Uncompahgre highlands. The northernmost part of the complex lies just downwind from the northwestern tip of the Uncompahgre highlands. Local variations throughout the remainder of the dunefield seem more closely related to proximity of the shoreline. Additionally, the lowland area was well exposed to storms that might have occurred in the eastern Pacific.

As with previous times, a clear relationship of wind deflections by major topographic features is not apparent. There is about as much scatter of data upwind as downwind from the Front Range and Uncompahgre highlands and the variations in orientation of the resultants in northern Arizona do not appear to be related to any known paleotopographic features.

\section{Source areas}

The source of much of the eolian sand most likely was from localities on or near the island-like landmass in the southern part of the study area as it seems unlikely that transportation of any appreciable amount of sediment across the shallow marine shelf to the north would have been possible. Presumably, the ultimate source of sand was the Uncompahgre and Front Range highlands and smaller exposed areas between them. Much of the sand would have been carried from these highlands to the shoreline by streams where clay and silt were winnowed out, leaving the sand to be redistributed by shoreline currents before being moved inland by winds. The sand in west-central Colorado, northeasternmost Arizona and, northwestern New Mexico probably was carried directly out of the beds of streams that originated in the Uncompahgre or Front Range highlands.

\section{Middle(?) and Late Triassic time}

Only a few small dune fields existed in the Western Interior during Triassic time. In Wyo- 
ming and north-central Colorado, the Jelm Formation contains two units that include eolian sandstone beds, the Middle(?) Triassic Red Draw Member and the Upper Triassic Sips Creek Member (Fig. 3). These beds, especially the Sips Creek, apparently correlate with eolian sandstones in the Crow Mountain Sandstone farther northwest in north-central Wyoming. Unfortunately, no crossbedding data are available from the Crow Mountain eolianites. The Rock Point Member of the Wingate Sandstone in northeastern Arizona and northwestern New Mexico also contains eolian strata and is here considered Late Triassic in age based on interfingering relationships with the $\mathrm{Up}$ per Triassic Chinle Formation (Peterson and
Pipiringos, 1979). Other small and lenticular eolian deposits may occur in the upper part of the Chinle Formation of central New Mexico (C.H. Maxwell, pers. commun., 1987) but they were not examined during the course of this study and no crossbedding data are known from them.

A small area containing Upper Triassic eolian sandstone was reported in Nova Scotia on the east side of North America by Hubert and Mertz (1980). These are in the Wolfville and Blomidon Formations although crossbedding dip vectors were only reported for the Wolfville.

\section{Paleogeography}

Considerable change occurred in the paleogeog-

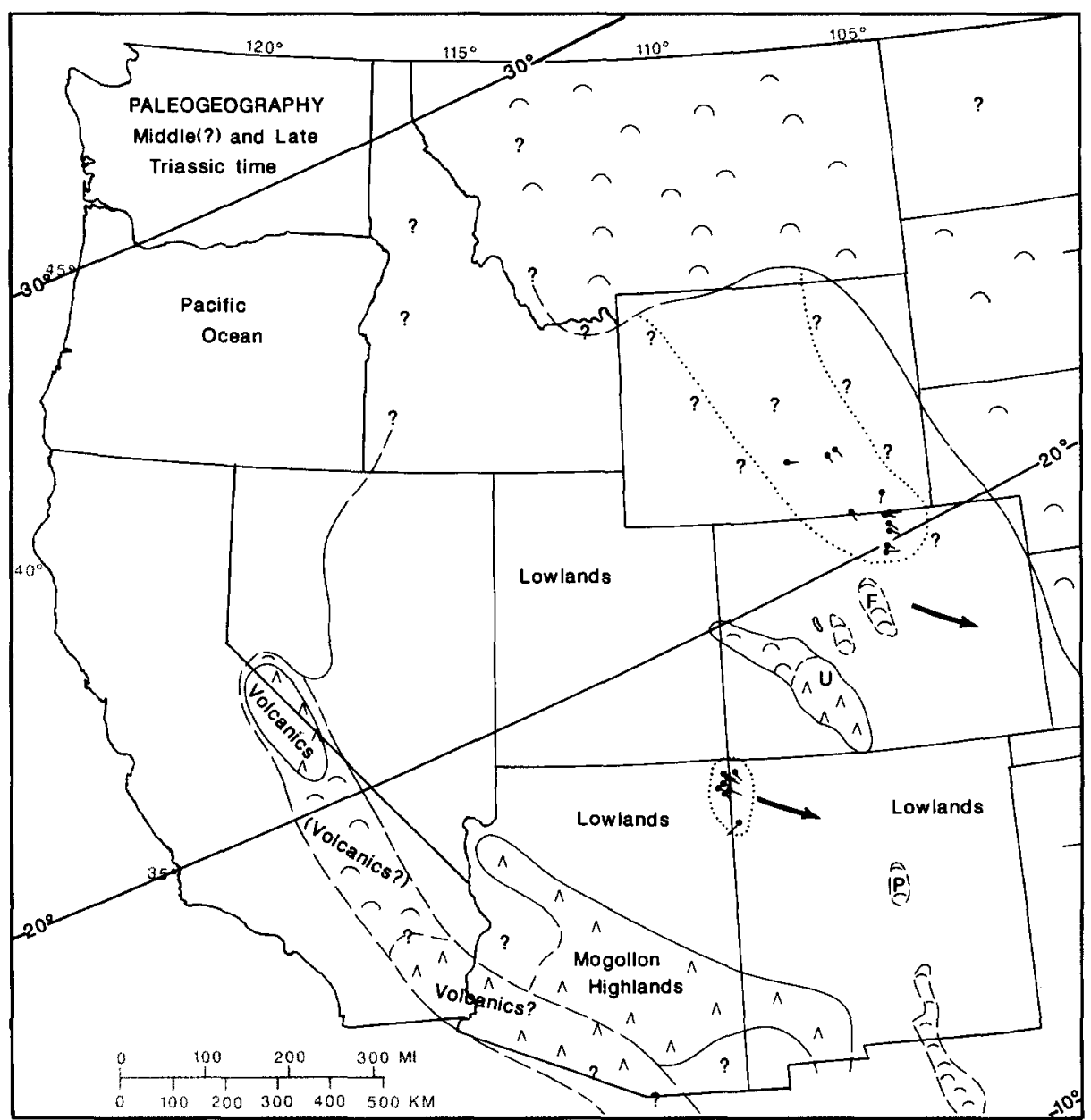

Fig. 9. Paleogeographic map for Middle(?) and Late Triassic time showing crossbedding resultants and paleolatitudes. The paleogeography is mainly for the early Late Triassic (Carnian Age). Large arrows indicate predicted wind patterns from Parrish and Peterson (this volume). 
raphy of the western United States during the Early to Middle Triassic interval, resulting in a considerable westward expansion of the land area by Late Triassic time (Fig. 9). This is exaggerated somewhat on the paleogeography map because palinspastic corrections were not made and considerable extension occurred in the Basin and Range province in late Cenozoic time. The continental interior east of the study area was emergent and probably consisted of extensive lowlands (McKee et al., 1959).

The Late Triassic shoreline lay in southern California and western Nevada; it probably extended northward from central Nevada but at the present time it cannot be reconstructed there because the continental margin was truncated by faulting later in Mesozoic time and the location of the moved terranes has yet to be determined. Some guidance to the location of the shoreline in western Nevada is given by Silberling and Wallace (1969) who described a deltaic complex in the Upper Triassic Grass Valley Formation in the vicinity of the Humboldt Range. Farther south but still in west-central Nevada, Speed (1978a, b) described fluvial and deltaic rocks intercalated with marine strata, thereby providing another location for the Late Triassic shoreline.

A volcanic region in southwestern Nevada and adjacent parts of California can be inferred from several studies. Fossiliferous marine deposits intercalated with marine and terrestrial volcanics are present in roof pendants of the southern Sierra Nevada (Fiske and Tobisch, 1978; Saleeby et al., 1978) and indicate an oscillating shoreline in that area. Bordering that region on the east is an area of plutonic siliceous rocks that apparently mark the locus of the igneous activity (Kistler, 1974; Stern et al., 1981). Thermal expansion of the crust may have made this the topographically highest part of the region although this does not necessarily imply that it was mountainous. Subaerial volcanic rocks, some of which have not been well dated, have also been found farther east and southeast in California and Nevada (Speed, 1978b; Dunne et al., 1978).

The volcanic terrane is not continuous across southeasternmost California, although this may be obscured by later transcurrent faulting. One indi- cation that the volcanic terrane continued farther southeast is suggested by volcanic pebbles and cobbles in the Upper Triassic Chinle Formation of the Colorado Plateau. This formation contains clasts of isotopically dated Upper Triassic volcanic materials in fluvial strata that came from somewhere south of the Colorado Plateau, although today, the region south of the plateau is notably lacking in Upper Triassic volcanic rocks. In attempting to explain the discrepancy, Stewart et al. (1986) offered the possibility that lateral movement of the source area along the Mojave-Sonora megashear (Silver and Anderson, 1974; Anderson and Schmidt, 1983) may account for lack of volcanic source rocks south of the Colorado Plateau. Lateral movement along that or another fault may also account for the lack of Upper Triassic volcanics in southeasternmost California, although the amount of translation would have been considerable-on the order of $700 \mathrm{~km}$ - even if Basin and Range extension is taken into consideration. Moreover, the recent discovery of a cratonic Paleozoic and Mesozoic sequence in northwestern Mexico about $50 \mathrm{~km}$ southeast of Yuma, Arizona, suggests that the megashear did not extend into the United States (Leveille and Frost, 1984). More isotopic dating of igneous rocks is needed in southern Arizona, however, before that region can be eliminated as the source of the Upper Triassic volcanics.

The Western Interior was a region of generally low topographic relief although fairly small uplifts were present in several places. The Milk River uplift in Montana was slightly positive and supplied sands and muds to the depositional basin farther south (E.K. Maughan, pers. commun., 1987). The ancestral Front Range and Uncompahgre uplifts in Colorado were an eastern source for fluvial deposits in the Chinle Formation of the Colorado Plateau (Poole, 1961; Stewart et al., 1972; Blakey and Gubitosa, 1984). A southern source of Chinle fluvial sediment was the Mogollon highlands of southern Arizona and perhaps northern Mexico (Stewart et al., 1972). Chinle fluvial deposits that came from the south contain chert pebbles with late Paleozoic fossils (Stewart et al., 1972), and the most likely source of this material is in central Arizona just south of the 
Colorado Plateau (Fig. 9). Volcanic constituents in the formation may have come from the inferred volcanic arc farther south that may have been faulted away at some later date. Other small areas of low hills in central and southern New Mexico, the remnants of Late Paleozoic uplifts, formed the drainage divide between the Chinle depositional basin to the west and the Dockum depositional basin farther east in eastern New Mexico and adjacent parts of Texas (McGowen et al., 1983).

Dune fields probably were small in Middle(?) and Late Triassic time. In the Middle(?) Triassic, a small dune field represented by the Red Draw Member of the Jelm Formation lay in southeastern Wyoming and north-central Colorado. Late Triassic dune fields in central Wyoming (Sips Creek Member of the Jelm Formation, Crow Mountain Sandstone) formed the largest known dune field of the time. Another but considerably smaller dune field lay in northeastern Arizona and northwestern New Mexico (Rock Point Member of the Wingate Sandstone). In central New Mexico, scattered eolian sandstone lenses in the Chinle Formation have also been found (C.H. Maxwell, pers. commun., 1987) but their distribution is unknown. Absence of eolian sands in the Early Triassic and their scarcity in the Middle(?) and Late Triassic make this period anomalous in the otherwise long continuum of eolian deposition throughout much of Pennsylvanian-Jurassic time in the Western Interior. Scarcity of eolian units in the Triassic is best explained by the somewhat wetter climate that probably prevailed over the western part of the U.S. (Parrish and Peterson, this volume).

Eolian sandstones in the Wolfville Formation

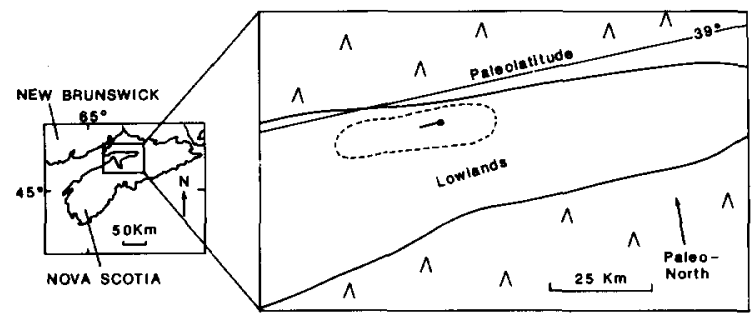

Fig. 10. Paleogeographic map for Late Triassic time in the Fundy Basin area, Nova Scotia, showing crossbedding resultant and paleolatitude (after Hubert and Mertz, 1980). of Nova Scotia were deposited on the north side of a west-southwest-trending valley that was bordered by highlands farther north and south (Fig. 10; Hubert and Mertz, (1980).

\section{Paleowinds}

The summary resultant from the small amount of available data indicates that Triassic winds in the Western Interior were northwesterly although the mode on the rose diagram shows west-northwesterly winds (Fig. 6). These are north-northwesterly winds in terms of paleocoordinates and the mode would have reflected northwesterly winds. All things considered, the distribution is fairly tight and possesses few anomalous resultants, as indicated by the relatively high consistency factor of 0.86 . However, the rose diagram is highly asymmetrical with the mode lying next to a quadrant containing no resultants. No reason for the asymmetry is apparent, leading one to suspect that additional data would yield some resultants in the northeast quadrant. All of the dune fields were well inland although lack of palinspastic corrections on the map exaggerates the distance separating the shoreline from the dunes.

According to Hubert and Mertz (1980), the Upper Triassic eolian beds of Nova Scotia yielded crossbedding resultants dipping to the west-southwest.

\section{Source areas}

Presumably, the sources of the Triassic dune sands were local and just upwind from the dune fields. The source of the eolian sand in the Four Corners area is unclear but most likely it was derived from fluvial and related sands of equivalent age in the Church Rock Member of the Chinle Formation farther upwind. These, in turn, were derived from highlands or low hilly areas in southern Arizona and central Colorado.

Eolian deposits in the Jelm Formation probably came from the Milk River uplift farther northwest. Correlative rocks in that direction are the Crow Mountain Sandstone, which, along with the Jelm, may have formed a belt of dunes extending southeastward from the uplift.

Eolian sandstones in the Woifville Formation of Nova Scotia are intercalated with fluvial beds 
that had a source in nearby highlands farther north (Hubert and Mertz, 1980). The close association of fluvial and eolian deposits suggests that the dune sand came from nearby stream beds.

\section{Earliest Jurassic time}

A fairly large erg represented by the Lukachukai Member of the Wingate Sandstone lay in southeastern Utah and nearby areas during earliest Jurassic time (Fig. 11). The relationships of these beds to formations farther north and northwest are not clear, at present, so a paleogeographic map was not constructed. The most reasonable stratigraphic interpretation is that the Lukachukai cor- relates with eolian beds in northeastern Utah that are included in the lower part of the Nugget or Glen Canyon Sandstones.

\section{Paleogeography}

The paleogeographic setting was similar to that depicted during late Early Jurassic time with an important exception; a large arm of the sea may have extended well inland from the Pacific. Doelger and Steidtmann (1985) report intertidal deposits of approximately the same age as the Lukachukai in the lower part of the Nugget Sandstone of central Wyoming (Bell Springs Member of Pipiringos, 1968) and Davis (1977) found tidal deposits in the Dinosaur Canyon Member of the

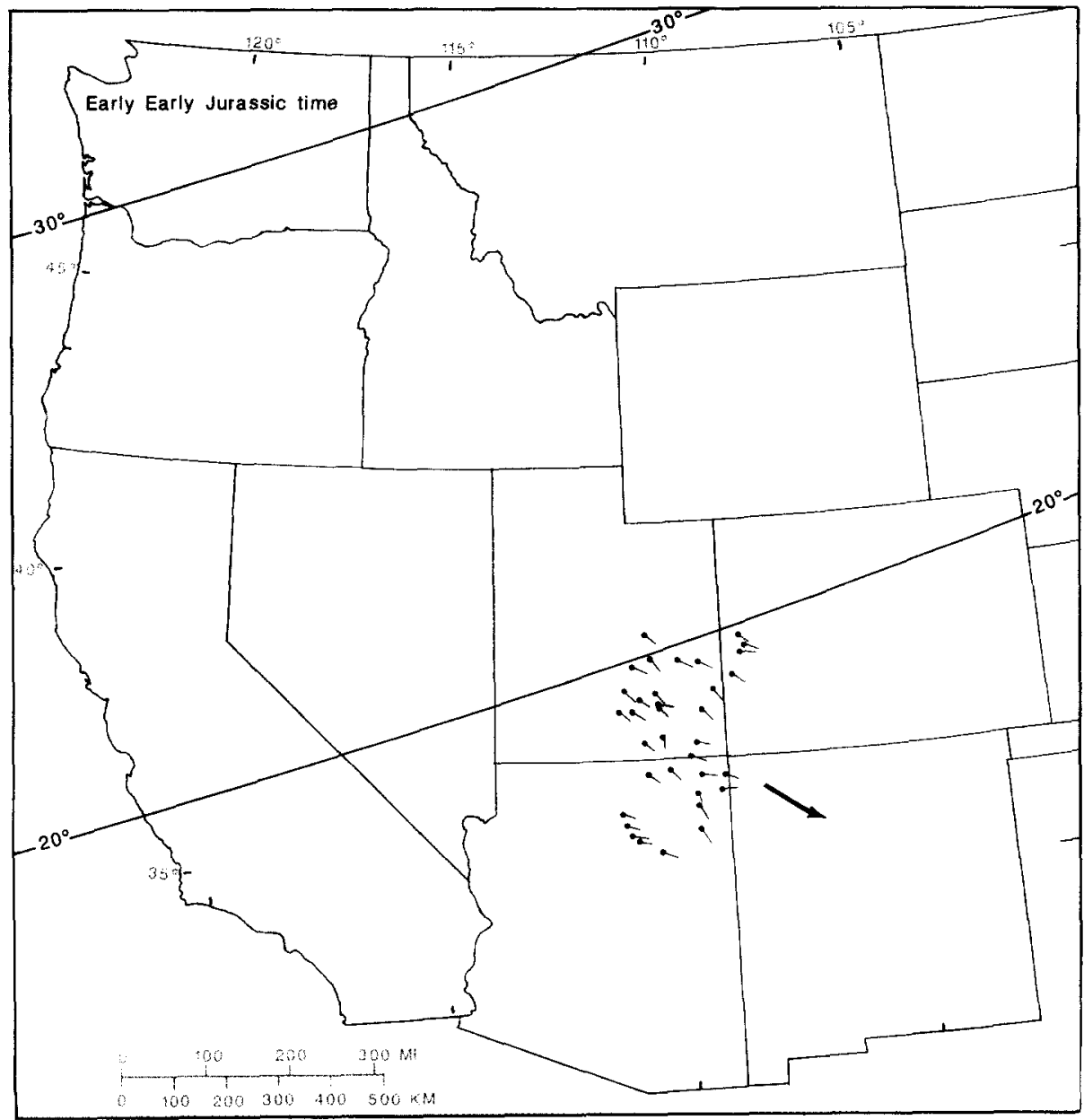

Fig. 11. Distribution of crossbedding resultants from lowermost Jurassic strata showing paleolatitudes. Large arrow indicates predicted wind pattern from Parrish and Peterson (this volume). 
Moenave Formation, a correlative of the Lukachukai, in southwestern Utah. The configuration of the seaway is not clear, at present, and even its presence is subject to some question. The seaway probably followed the trend of the Middle Jurassic embayment and had a fairly small outlet in southern Idaho.

\section{Paleowinds}

Crossbedding resultants obtained from the Lukachukai Member of the Wingate Sandstone indicate deposition by northwesterly winds. North in Early Jurassic time was close to present north and the wind was, for all intents and purposes, from the northwest in terms of paleocoordinates. There is little scatter in the data (Fig. 11), as indicated by the high consistency factor of 0.94 (Fig. 6), which is the highest obtained in this study. The high consistency factor demonstrates a strong tendancy for unidirectional winds across the entire dune field. However, this may be misleading. Comparison with resultants obtained from slightly younger upper Lower Jurassic strata, which cover a far larger area, suggests that greater variation may have been found had the dune field extended farther west. The Lukachukai Member is easily identified throughout the area containing resultants on the map, so problems with correlation outside that area, mentioned in preceding paragraphs, need not be considered in analyzing the resultants.

\section{Source areas}

The sand that supplied the Lukachukai erg came from upwind areas farther northwest. Presumably, this was from shoreline deposits along the eastern coast of the seaway alluded to earlier. That sand, in turn, may have come from erosion of strata in Nevada and western Utah or from farther north in the Wyoming-Idaho area. Until a clearer picture of the paleogeography of the region arises, it will remain difficult to obtain a better understanding of the source of sand in the Lukachukai.

\section{Late Early Jurassic time}

The largest erg known to have existed in the Western Interior is represented chiefly by eolian sandstone beds in the Aztec Sandstone (eastern Nevada, southeastern California), Glen Canyon Sandstone (northwestern Colorado), Navajo Sandstone (northern Arizona, southeastern Utah, southwestern Colorado), and Nugget Sandstone (western Wyoming, southeastern Idaho, northeastern Utah; Fig. 3). Eolian strata also occur in approximately correlative formations of southern Arizona where different names are applied to essentially the same rocks in each of several mountain ranges. These include the Ali Molina Formation in the Baboquivari Mountains, the Cobre Ridge Tuff of Bilodeau and Keith (1986) at Cobre Ridge, the Mt. Wrightson Formation in the Santa Rita Mountains, the Ox Frame Volcanics in the Sierrita Mountains, and the Sil Nakya Formation in the Sil Nakya Hills (Bilodeau and Keith, 1986). Approximately correlative rocks in western Nevada that might be eolian are the quartzitic sandstone of the Singatsee Range (Proffett and Dilles, 1984) and the Sandstone of McGery Canyon in the Paradise Range (N.J. Silberling, pers. commun., 1986). The rocks in both ranges in Nevada have been metamorphosed to quartzites, making it difficult to confidently identify their original environment of deposition.

There are few age constraints on these units, although an Early Jurassic age is commonly accepted from the available evidence (Peterson and Pipiringos, 1979; Bilodeau and Keith, 1986). Regionally, the lower contact of the eolian beds tends to rise stratigraphically and is younger to the south owing to interfingering and lateral replacement by underlying units. This, plus the lack of stratigraphic markers, the considerable thickness of the units, and the unconformity at the top, make it difficult to gain an understanding of the stratigraphic relationships and original extent of the erg-forming complex as a whole. Thus, the maximum extent of the erg as depicted on the map (Fig. 12) may be somewhat misleading. It is conceivable that at any given instant in the geologic past the erg was considerably larger or slightly smaller than that indicated on the map.

\section{Paleogeography}

The general paleogeographic setting of the western United States was similar to that of the 


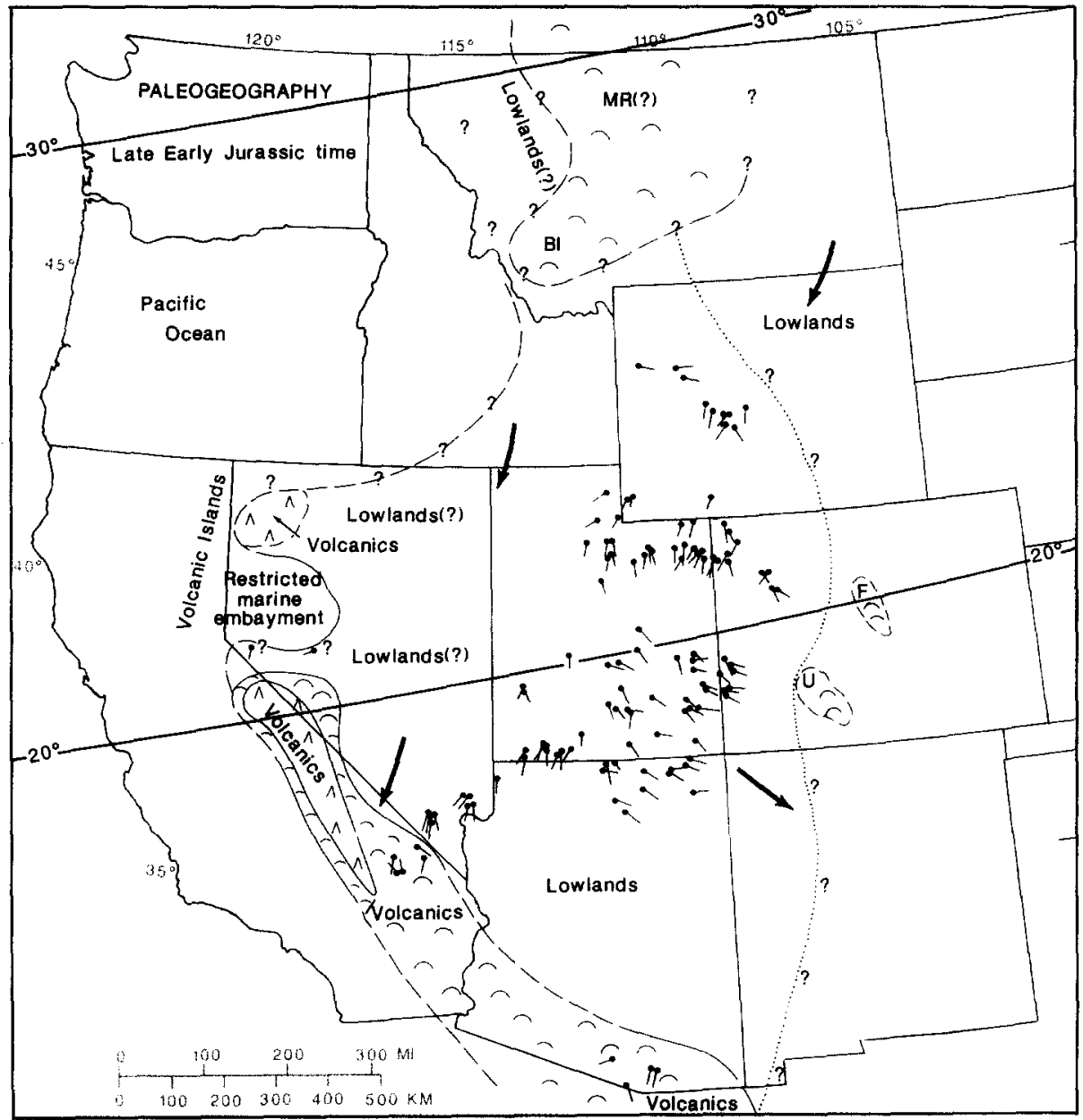

Fig. 12. Paleogeographic map for late Early Jurassic time showing crossbedding resultants and paleolatitudes. The paleogeography is mainly for the latest Early Jurassic (Toarcian Age). Large arrows indicate predicted wind patterns from Parrish and Peterson (this volume).

Late Triassic although the climate was drier. Most of the region was a broad lowland area occupied by a vast erg whose original dimensions are unknown although the preserved parts indicate it was large (Fig. 12).

The eolian sand sea may have been bordered on the north by a fairly large upland area of low hills marked by the Milk River uplift, which is hypothesized on the slim basis that it may well have continued from earlier times, that considerable uplift and erosion is known to have occurred there for some significant extent of Late Paleozoic to Middle Jurassic time and that it is progressively overlapped by successively younger Jurassic strata. Low hills may have existed at the site of the ancestral Front Range and perhaps the southern part of the Uncompahgre uplift, but there is no known evidence for this within the late Early Jurassic eolian deposits.

The presence of these uplifts may be inferred from the Kayenta Formation, which is a fluvial sandstone unit that interfingers with basal strata of the Navajo Sandstone. The Kayenta was derived from the ancestral Front Range, indicating that the range was an elevated topographic feature at the beginning of deposition of the Navajo erg. The Lukachukai Member of the Wingate Sandstone lies stratigraphically beneath the Kayenta and extends as far east as Rifle, Colorado, which is east of the northern part of the ancestral Un- 
compahgre uplift. This demonstrates that the northern part of the Uncompahgre was not a source area for the Kayenta and, similarly, may not have been a positive topographic feature during deposition of the Navajo Sandstone either although it is conceivable that farther south where the entire Glen Canyon Group is missing, the southern part of the Uncompahgre may have been a topographic high. Fluvial deposits have been found in the Middle Jurassic Entrada Sandstone near the north flank of the ancestral Front Range (Kocurek, 1981), suggesting that the uplift may have existed throughout the late Early Jurassic.

The nature of the terrane in south-central Arizona just south of the Mogollon Rim is not clear. The Mogollon highlands have been hypothesized to occupy this portion of the state and to have been the source of coarse clastic debris in Upper Triassic and lowermost Jurassic fluvial units of the southern Colorado Plateau. However, whatever lay in this region must have been topographically low to allow wind-blown sand from the erg to pass over it and accumulate farther south in southern Arizona. Unfortunately, rocks of Early Jurassic age are not preserved in any significant part of this critical area. Eolian sandstone that is thought to correlate with the Aztec Sandstone has recently been discovered in Mexico about $50 \mathrm{~km}$ southeast of Yuma, Arizona (Leveille and Frost, 1984). These deposits are important, not only because they help to define the extent of the late Early Jurassic sand sea, but also because their presence this far south indicates that the Mojave-Sonora megashear of Anderson and Schmidt (1983) did not extent into Arizona and may not exist at all (Leveille and Frost, 1984; Hamilton, in press).

A magmatic arc formed a narrow but elongate highland or low hilly area along the southwestern border of the continent, as suggested by a northwest-trending belt of siliceous plutonic rocks that mark the underpinnings of the arc (Armstrong and Suppe, 1973; Kistler, 1974). The shoreline probably lay close to the southwestern margin of the highland, as suggested by alluvial fan and shallow marine(?) deposits of approximately this age in the Fairview Valley Formation at Black Mountain, California (Miller, 1978) and by inter- bedded marine and terrestrial volcanic deposits in roof pendants of the southern Sierra Nevada (Fiske and Tobisch, 1978; Saleeby et al., 1978). Pure quartz sandstone in beds just above the Fairview Valley Formation (Miller, 1978) and pure orthoquartzite beds in roof pendants in the southern Sierra Nevada are thought to be sediment from the erg that was blown or carried by streams into shallow marine waters in these areas (Saleeby et al., 1978).

On the northeast side of the highlands, a convenient location for the boundary between highlands and low hills is determined roughly by onlap of eolian sandstones of the Aztec Sandstone against highlands in the arc. The southwesternmost exposures of the Aztec Sandstone and correlative eolian beds that help in delineating the southwestern extent of the erg are in Mexico about $50 \mathrm{~km}$ southeast of Yuma, Arizona, at Cave Mountain (Burchfiel and Davis, 1981); the Cowhole Mountains and nearby areas (Marzolf, 1983, a, b); at or near the Big Maria Mountains (Hamilton, 1982) in southeastern California; and in several ranges in the central part of southern Arizona (Bilodeau and Keith, 1986). The northeast limit of siliceous plutonic rocks of the same approximate age (Burchfiel and Davis, 1981) also offers a guide to the northeastern boundary of the arc. The arc is shown as a low hilly area in southeastern California because dated plutonic rocks of Early Jurassic age are scarce there. The erg lapped onto highlands or low hilly areas of the magmatic arc (Marzolf, 1983a) and it may have extended completely across the arc to the shoreline in some places.

Northward extension of the arc offshore or locally adjoining parts of the shoreline in northwestern Nevada and northeastern California is suggested by strata in the Jackson Mountains in the northwestern corner of Nevada. Here, the approximate position of the shoreline is suggested by Upper Triassic to Upper Jurassic volcanogenic sedimentary rocks, lava flows, and volcanic-flow breccias that accumulated in subaqueous environments as well as subaerial environments suggestive of highlands (Russell, 1984). The configuration of the mainland shoreline northeast from the Jackson Mountains across southern Idaho is purely hypo- 
thetical. Islands or peninsulas associated with the arc probably formed constrictions to a small marine embayment in west-central Nevada where evaporite deposits, notably gypsum, were deposited (Speed, 1978b). The eastern part of this embayment also was the site of accumulation of clean quartz sand that makes up the bulk of the Boyer Ranch Formation, which is interpreted as a shallow-water nearshore deposit that received its sediment from a dune field-presumably the Aztec erg - that lay nearby to the north and east (Speed and Jones, 1969).

Exposures of quartzite of probable Early Jurassic age at two localities just south of the hypothesized embayment in western Nevada (Fig. 12) may well be remnants of the late Early Jurassic dune field. However, the rocks are highly metamorphosed; only the gross aspects of their sedimentary structures are identifiable and a positive determination of their environment of deposition could not be made. Proffett and Dilles (1984) considered the quartzose sandstone of the Singatsee Range (the westernmost resultant in Fig. 12) eolian in orgin, but they offer no explanation for the determination and presumably it was made on the basis of maturity and the moderately large size of the crossbed sets (as much as about $1.3 \mathrm{~m}$ ). Suggestions of excellent rounding along small segments of the original grain boundaries can be seen in thin-sections, but most of the grain boundaries show intense pressure solution, and, even under the best of conditions, excellent rounding cannot be considered diagnostic of eolian environments. Similar features were found in the Lower Jurassic sandstone of McGery Canyon in the Paradise Range farther east (the eastern locality in western Nevada with a questioned resultant in Fig. 12) although some of the crossbed sets reach $2 \mathrm{~m}$ in thickness and a few may be thicker (N.J. Silberling, pers. commun., 1987). In summary, the crossbedded upper Lower Jurassic quartzites of western Nevada may be eolian deposits but a conclusive determination awaits further work.

Paleogeographic reconstructions by Stanley et al. (1971) show a large marine embayment in the western part of the Western Interior during Early Jurassic time. Although they felt that the late Early Jurassic erg graded westward into shallow marine environments in eastern Nevada, the presence of eolian(?) beds in western Nevada, the need for a northern and (or) northeastern (upwind) source for sand in the Boyer Ranch Formation in the same general area, and the lack of meaningful exposures of the Aztec Sandstone near Currie in northeastern Nevada, all argue for continuation of the erg across much of Nevada. (The Currie locality has poor or limited exposures of a flat-bedded sandstone that is correlated with the Aztec Sandstone. Other lithologies in it probably should be included in the Upper Triassic Chinle Formation. Faults are common there and a thickness of less than a hundred to perhaps a few hundred meters is all that can be reasonably inferred; much of the formation appears to be missing.) The paleogeographic interpretations of Stanley et al. (1971) may still hold but their interpretation fits best with the envisioned paleogeography of the region during deposition of the Lukachukai Member of the Wingate Sandstone.

The eastern limit of the vast late Early Jurassic erg cannot be determined because the deposits were truncated eastward prior to deposition of Middle Jurassic rocks.

\section{Paleowinds}

Late Early Jurassic winds determined from the crossbedding show a general southward trend, both in terms of present and Early Jurassic coordinates. Although there are important variations, the overall pattern is fairly uniform with a fairly high consistency factor of 0.75 (Fig. 6). There is a tendancy for significant deviations in several parts of the region even though the resultants tend to dip consistently within the individual parts.

Eastward-dipping crossbedding in the northernmost part of the eolian sandstone complex in northwestern Wyoming may be related more to the stratigraphic position of the measurements, which came from the lowermost beds of the eolian part of the Nugget Sandstone, than to any significant regional change in atmospheric circulation in that area. The upper beds of the Nugget in this area were beveled out by erosion prior to deposition of overlying rocks. Crossbedding in the lowermost beds of the eolian sandstone complex farther south tend to dip more to the east than crossbed- 
ding in higher beds (Marzolf, 1983b). An east-dipping trend is not apparent farther southeast in central Wyoming where the easternmost readings also were made near the base of the eolian part of the Nugget, but perhaps the measurements there were not made as close to the edge of the Nugget as the more northerly measurements. In summary, eastward-dipping crossbedding in the northernmost part of the erg complex may only reflect atmospheric circulation patterns during deposition of the lowest beds of the Nugget Sandstone rather than circulation patterns during deposition of the bulk of formation.

Southeast-trending resultants in southeastern Utah and adjoining areas embrace an area with dip directions consistently at a high angle from the regional pattern (Fig. 12). No orographic effect is apparent from the paleotopography as no elevated topographic features are known or thought to have existed near there. The ancient Uncompahgre and Front Range uplifts most likely were subdued topographic features and probably lay east of the dune field, or at least east of the remnants of the dune field that we see today.

Curiously, two resultants in the Cowhole Mountains of southeastern California dip to the north or northwest, nearly $180^{\circ}$ from the regional south to south-southwest pattern in the same general area (Marzolf, 1983b; Porter, 1985). This may be the result of extreme local variation in wind patterns due to the influence of topography where the erg lapped onto topographic highs of the magmatic arc. However, it seems more likely to have been the product of extreme tectonic rotation of the Cowhole Mountains crustal block about a vertical axis due to movement on nearby strike-slip faults (Marzolf, 1983b), as is known to have occurred later in the same general area (Carter et al., 1987). Paleomagnetic as well as sedimentologic studies of transportation directions in other strata could also provide clues to the true structural orientation of the Cowhole Mountains.

Moderate variations between crossbedding resultants in southern Arizona may be the result of local orographic effects, insufficient measurements, or later structural movements.

\section{Source areas}

The source of most of the sand in the Aztec-Navajo-Nugget erg must have been upwind to the north or northwest and most likely was the uplifted area of central Montana and adjoining areas, perhaps as far north as Canada. Some of the sand eroded from the west side of this uplift could have been carried west by streams and then south by shoreline currents in marine waters that must have been present either in western Montana or a relatively short distance farther west. Perhaps this was a major source of sand during the early stages of deposition of the erg when there was a greater tendancy for the winds to come from the northwest (Marzolf, 1983b). Derivation from sedimentary terranes that included older eolian sandstones (Quadrant and Tensleep Sandstones), coupled with reworking in the surf zone, may account for the extreme maturity of the sands.

\section{Middle Jurassic time}

Only part of the Entrada Sandstone-the most extensive eolian sandstone unit of Middle Jurassic age-is considered here (Fig. 13). Several other Middle Jurassic units of far smaller areal extent are also present on or near the Colorado Plateau (Figs. 3 and 14) but they are so small that they would contribute little to a regional analysis (see Blakey et al., this volume). The unit considered here is the lower part of the Entrada Sandstone, which can be broadly considered as a Colorado Plateau unit that extends eastward across the southern Rockies and into the western part of the Great Plains region (Fig. 13). The lower part of the Entrada includes the lower and middle members in south-central Utah, the lower sandy member in north-central Arizona, the Slick Rock Member along the southeastern Utah-southwestern Colorado border, and the undivided Entrada elsewhere. The upper and Cow Springs Members and the Moab Tongue are not included because they extend across fairly small areas, are slightly younger than the lower part of the Entrada, and have crossbedding dip vector resultants that differ 


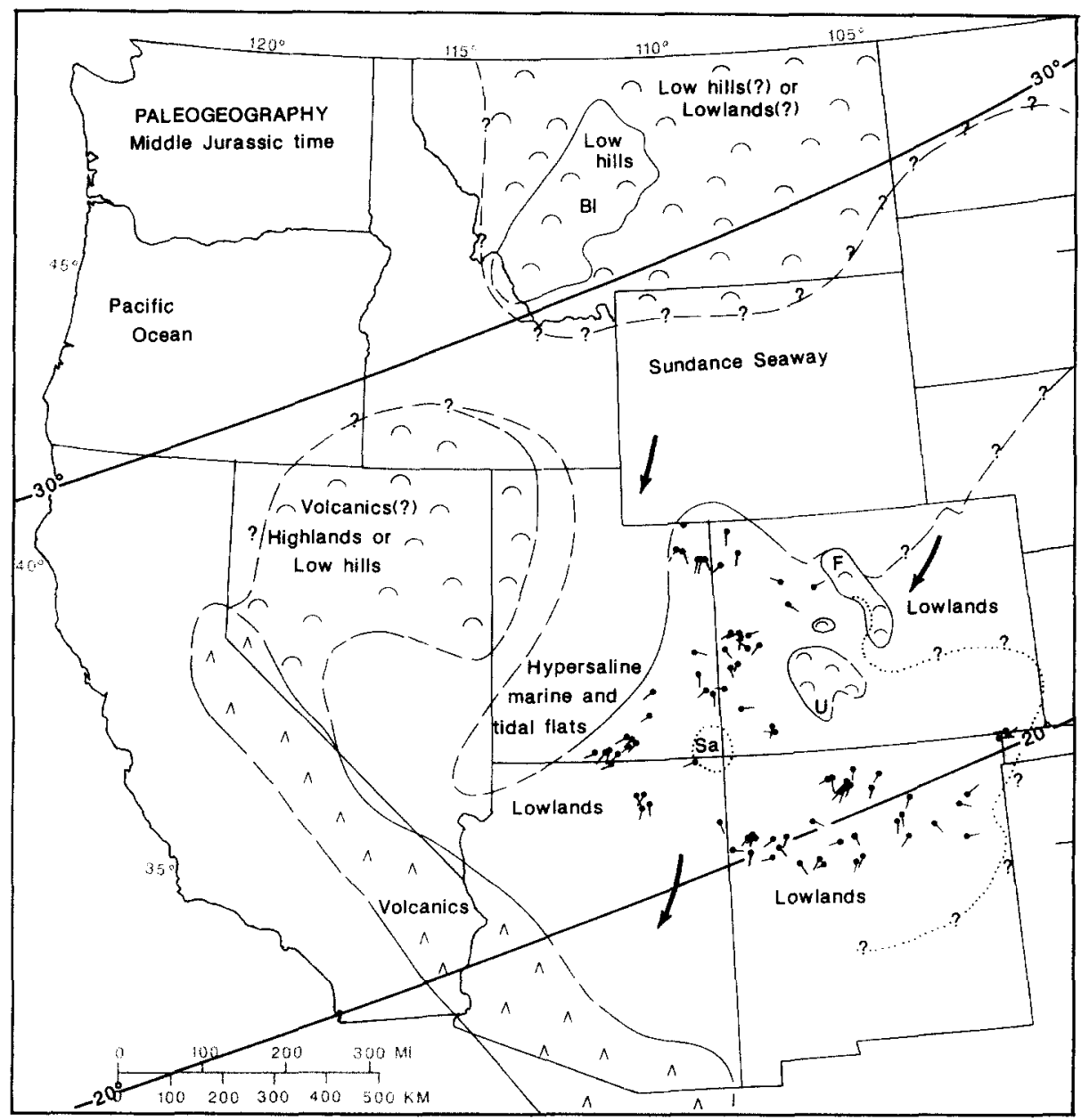

Fig. 13. Paleogeographic map for Middle Jurassic time showing crossbedding resultants and paleolatitudes. The paleogeography is mainly for the late Middle Jurassic (middle Callovian Age). Large arrows indicate predicted wind patterns from Parrish and Peterson (this volume). $S a=$ inland sabkha.

somewhat from those obtained from the lower part of the Entrada. Crossbedding resultants obtained from these units are presented on another diagram (Fig. 14).

The Canyon Springs Sandstone Member of the Sundance Formation is a shallow marine to partly eolian unit in Wyoming and adjacent parts of Colorado, Nebraska, and South Dakota (Rautman, 1978; Blakey et al., this volume). Only the southern part of it correlates with the Entrada (Pipiringos et al., 1969; Pipiringos, in Segerstrom and Young, 1972 Pipiringos and O'Sullivan, 1976, 1978) but the rest of the Canyon Springs is slightly older and equivalent to beds in the upper part of the Carmel Formation, which underlies the En- trada on the Colorado Plateau (Imlay, 1980; Pipiringos and O'Sullivan, 1978).

\section{Paleogeography}

The broad paleogeographic setting was similar to that of earlier times. The most significant differences are in the distribution of highlands or low hilly areas along the western and northern parts of the study area and in the presence of a large marine embayment, reminiscent of the late Paleozoic, in the central and northern parts of the region. The Entrada erg was of considerable areal dimensions and apparently second in size only to the late Early Jurassic erg complex.

An irregular and divided marine embayment, 


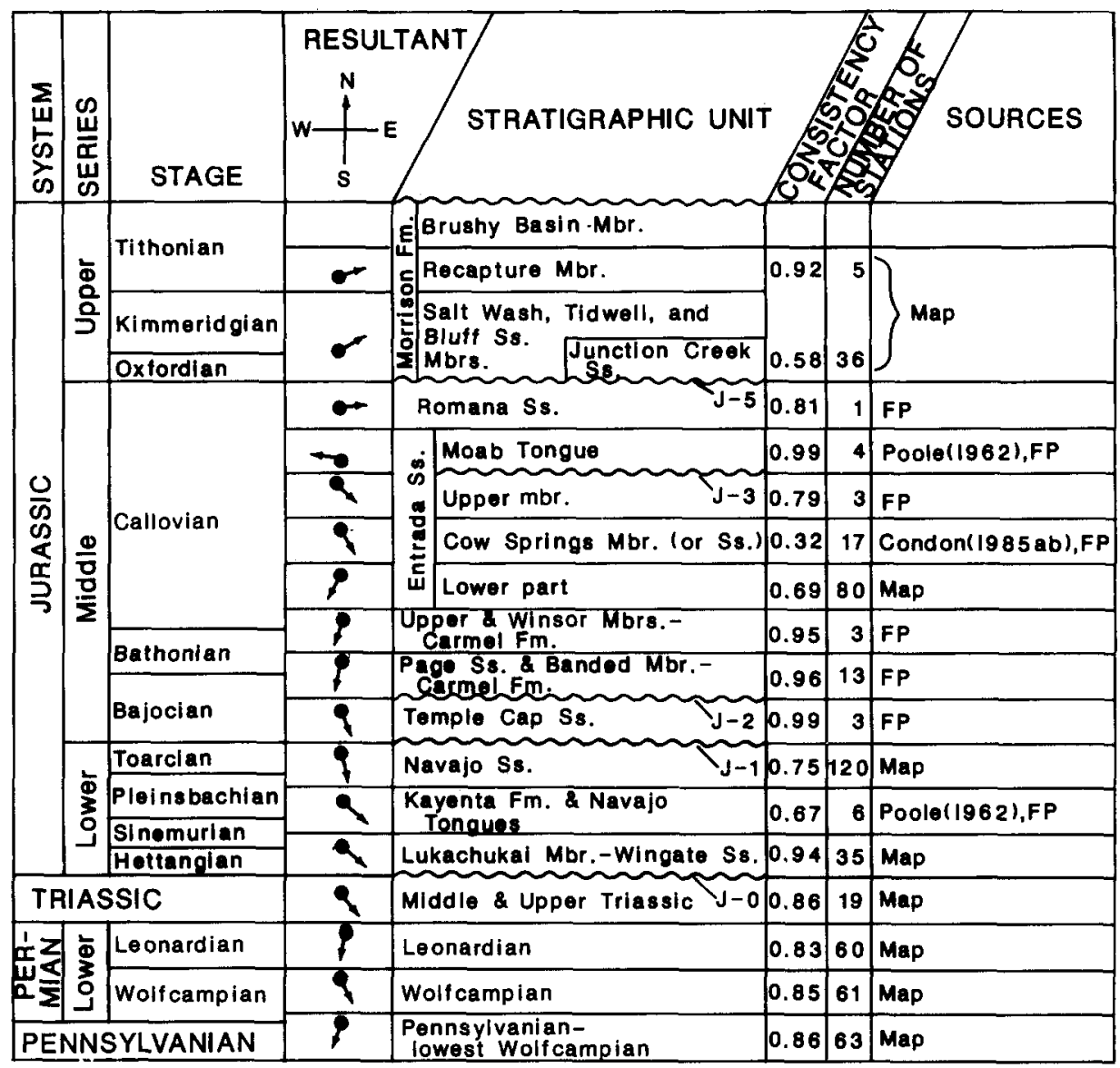

Fig. 14. Time-stratigraphic summary of crossbedding resultants from Pennsylvanian to Jurassic eolian rocks in the Western Interior. Compiled from the maps in this report with additional data in the Jurassic from Colorado Plateau units. The distribution of most of the eolian units not covered in this report is shown by Blakey et al. (this volume). FP= unpublished data by F. Peterson (this report).

known as the Sundance or Logan seaway, extended well inland across Wyoming and into the Dakotas during deposition of the Entrada Sandstone, with an arm that extended south across Utah and into southern Nevada (Fig. 13). The extent of the seaway in Wyoming and the Dakotas is largely from Imlay (1980). However, its northern shoreline was modified in northern Wyoming in accordance with surface and subsurface studies by Pipiringos and O'Sullivan (1978) and Peterson (1957) that show the shallow marine(?) equivalent of the Entrada-the Lak Member of the Sundance Formation - farther north in Wyoming than envisioned by Imlay (1980). The Lak Member apparently was beveled out northward during formation of the J-3 erosion surface. Hence, the shoreline may have been considerably farther north and perhaps in Canada. If so, however, the Belt Island trend most likely would have been emergent as it had been an active positive structural element during much of Jurassic time (Peterson, 1957; Imlay, 1980; Michaud, 1987). The shoreline configuration in southern Wyoming and northern Colorado was determined from stratigraphic relationships shown by Pipiringos (1968), Pipiringos et al. (1969), Pipiringos (in Segerstrom and Young, 1972), and Pipiringos and O'Sullivan (1978).

The southern or Utah arm of the Sundance seaway is best outlined by facies and structural relationships in deposits slightly older than the Entrada in the late Bajocian-early Callovian Carmel Formation. The Carmel underlies the Entrada or locally interfingers with it, but they are closely related by similar tectonic processes that 
governed the distribution of facies in both formations. The approximate axis of the Utah arm of the seaway is suggested by a south-southwestward-trending belt of fairly normal marine faunas in the Carmel that is bordered to the east and west by belts containing faunas indicative of restricted marine environments (Imlay, 1964), presumably because of shallow waters near land. The overlying Entrada grades westward into a restricted marine, tidal flat and sabkha facies (Twist Gulch Member of the Arapian Shale) restricted to the same approximate area as the Carmel seaway, suggesting a similar structural control on the distribution of facies in both formations. Thick Carmel marine limestones extend to the southwestern corner of Utah so extension of the arm of the seaway into southern Nevada, and of the structural sag that controlled its distribution, is indicated. If limestones in southern Nevada that are tentatively identified as the Carmel Formation by Bohannon (1983) should prove to be correctly identified, the argument would be even more compelling. The important point is that the same structure that localized Carmel deposition (a long downwarp extending south-southwestward across Utah) also localized Entrada deposition, and extension of the downwarp across Utah and into southern Nevada during deposition of the Entrada is likely.

An unconformity between the Rierdon Formation and overlying Swift Formation in Montana probably records an eustatic fall in sea level and erosion over a fairly large area in the northern part of the Western Interior at about the same time as deposition of the Entrada (Imlay, 1980). The shoreline in western Montana or east-central Idaho is not located well because the rocks that would aid in this determination were either removed during a Late Jurassic erosion event or moved some considerable distance by later faulting. Nevertheless, a large emergent area in the northern part of the Western Interior is suggested even though its configuration and areal extent are poorly defined (Imlay, 1980).

In central Colorado, a series of low hills is suggested in the vicinity of the ancestral Front Range and Uncompahgre uplifts by onlapping relationships of the Entrada, by scarce fluvial de- posits in the Entrada that radiate away from the northern part of the ancestral Front Range (Kocurek and Dott, 1983), and by truncation of the Entrada beneath the Upper Jurassic Morrison Formation (Tweto, 1976; Tweto et al., 1976; Scott et al., 1978; Tweto et al., 1978; Bryant et al., 1981). The abrupt southeastward termination of the Uncompahgre uplift is inferred from a well that penetrated an eolian sandstone unit belonging to either the Entrada or the Upper Jurassic Junction Creek Sandstone (Gries, 1985). The well is rather distant from known areas of Junction Creek (see isopach map in Blakey et al., this volume) so I tentatively consider the eolian unit to be Entrada.

A highland of unknown dimensions most likely existed in eastern Nevada and perhaps northwestern Utah that was the source of chert granules and small pebbles as much as $5 \mathrm{~mm}$ in diameter found in strata equivalent to the Entrada (Twist Gulch Member of Arapian Shale) at Saline Canyon, Utah. Hileman (1973) interprets a western source area for the Preuss Sandstone (a correlative of the Entrada) in her study area along the Idaho-Wyoming border. Additional support for a highland source area to the west is reported by Imlay (1967, p. 51) who found chert and quartzite pebbles as much as $2.5 \mathrm{~cm}$ in diameter in uppermost beds of the Twin Creek Limestone near Woodruff, Utah (stratigraphically, these beds are slightly older than the Entrada and are equivalent to the uppermost beds of the Carmel Formation that lie beneath the Entrada Sandstone on the Colorado Plateau). The source area could have been a Middle Jurassic uplift in northwestern Utah, northeastern Nevada and southeastern Idaho (Allmendinger and Jordan, 1981).

Tectonic activity resulting in uplift evidently occurred in much of the present-day Basin and Range Province during the Middle Jurassic. Considerable orogenic activity including thrusting occurred in western Nevada (Ferguson and Muller, 1949; Speed, 1974, 1978b) and Allmendinger and Jordan (1981) postulate Middle Jurassic thrusting in nortwestern Utah and adjacent southeastern Idaho although the thrusting postulated by Allmendinger and Jordan (1981) is not accepted by all workers in the region (T.F. Lawton, pers. com- 
mun., 1987). Middle Jurassic thrusting also occurred in and about the Inyo Mountains and northern Mojave Desert region of southeastern California (Dunne et al., 1978; Burchfiel and Davis, 1981). Just across the state line in the Toquima Range of southwestern Nevada, F.G. Poole (pers. commun., 1987) identified a thrust that may be of the same age or slightly younger (the thrust cuts Triassic strata and, in turn, is cut by an Upper Jurassic dike). Some igneous activity suggestive of thermotectonic uplift in Nevada is indicated by several scattered late Middle Jurassic plutonic rocks (Armstrong and Suppe, 1973; Allmendinger and Jordan, 1981; Sargent and Roggensack, 1984) but the number of dated plutons in this area is not nearly as great as it is for the Late Jurassic.

The main part of a magmatic arc bordered the southwestern part of the continent in southeastern California, southern Arizona and Mexico, forming a volcanic highland area separating the Pacific Ocean from the Western Interior. The arc is recognized by scattered plutonic rocks aligned in a belt that stretches southeastward from east-central California to southern Arizona and on into Mexico (Armstrong and Suppe, 1973; Kistler, 1974; Stern et al., 1981).

Middle Jurassic eolian sands covered a large part of the southern Western Interior (Fig. 13). The erg represented by the Entrada Sandstone covered most of the Colorado Plateau and extended at least as far east as westernmost Oklahoma (Finch and Wright, 1983; Snoparsky, 1986). Low hills of bedrock rose slightly above the Entrada dune field in central Colorado. Lack of any significant amount of coarse material in the Entrada there suggests low topographic relief although Kocurek (1981) found evidence of some fluvial transportation away from these hills.

Small areas of sabkha deposits characterized by contorted bedding and scarce adhesion ripples or warts in silty sandstones are common in the Entrada and suggest that the erg was not a monotonous dune field. A fairly large area of sabkha deposits was centered about the Four Corners area. Stratigraphic sections measured in this area by O'Sullivan $(1978,1980)$ show that although it expanded and contracted through time, this inland sabkha nevertheless persisted throughout Entrada deposition and, evidently, was never covered by the dune field.

The southern extent of the Entrada dune field is unknown. Jurassic eolian beds have been found in southern Arizona but, although poorly dated, they appear to be Early Jurassic in age as their grain size is slightly larger than that of typical Entrada sand. Although not conclusive evidence, the upper fine-grained to lower medium-grained sand found in these beds is characteristic of the Lower Jurassic Navajo and Aztec Sandstones, in contrast to lower and upper fine-grained sand that is regionally characteristic of the Entrada.

\section{Paleowinds}

Entrada crossbedding dips to the south-southwest and is only moderately consistent, as indicated by the consistency factor of 0.64 (Fig. 15). In terms of paleocoordinates, the sands were deposited by northeasterly winds. There is a fair

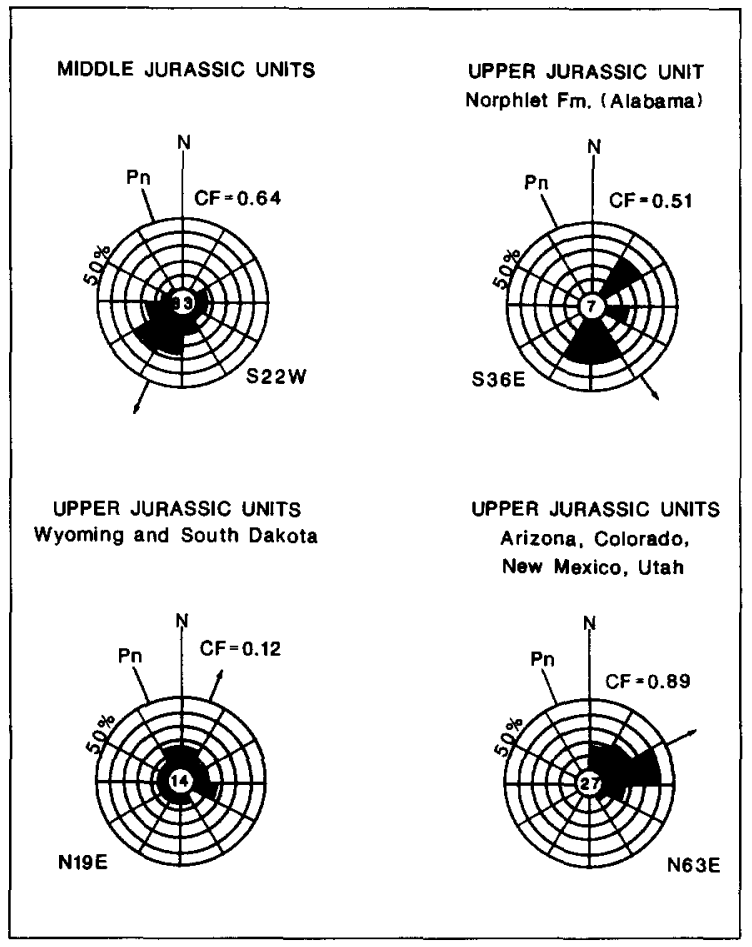

Fig. 15. Rose diagrams of Middle and Upper Jurassic crossbedding resultants from maps in this report. The number of resultants used is given in the center and the arrow and bearing are of the summary resultant. $N=$ present north; $P N=$ paleonorth; $C F=$ consistency factor. 
amount of variation in the resultants but it is not consistent in most areas and, instead, strongly opposed resultants may lie close to each other.

A large marine embayment (or lake) represented by the Todilto Limestone Member of the Wanakah Formation stretched across north-central New Mexico (Hilpert, 1969) and probably connected with the Sundance seaway through a narrow strait that most likely was in west-central Colorado (Ridgley, 1984). The embayment only existed for a short time during deposition of a small part of the middle Entrada so anomalous wind patterns that might have been related to the embayment would only have been present for a short time.

Tanner (1965), Vincelette and Chittum (1981) and Reese (1984) showed that the Entrada of north-central New Mexico contains large linear sand bodies (possibly longitudinal dunes) that, on outcrops, contain crossbedding that dips at an appreciable angle from the axis of the sand body. The sand bodies are so large that crossbedding measurements in any local outcrop area probably would not include both sides of any of these features and, therefore, the relatively small size of areas selected for crossbedding studies could account for some of the variation in the resultants. However, it seems unlikely that this could account for resultants that are oriented more than $90^{\circ}$ from the regional south-southwest trend of the data.

The influence of major geographic features on atmospheric circulation patterns during deposition of the Middle Jurassic Entrada erg was varied. Significant orographic features such as the highlands in California and Nevada were well removed from the erg, at least from what is presently preserved of the erg, and do not appear to have affected wind patterns over the Entrada sand sea. Moreover, there is no apparent influence of the low hilly areas in central Colorado on the circulation patterns. At least part of the variability in crossbedding resultants from the Entrada may be related to proximity to the Sundance seaway. The Entrada erg was bordered on the north and west by arms of the seaway and it is conceivable that proximity to so much water and the attendant land-sea temperature contrast could have caused much of the variation in wind patterns. This may account for varied wind patterns near the shoreline but the influence of shoreline temperature contrasts on eolianites several hundred kilometers inland, such as in northern New Mexico, would appear to be minimal.

In conclusion, the cause of variation in orientation of crossbedding resultants in most of the Entrada eolian deposits does not appear to lie with local geographic features and, instead, may be related to broader aspects of atmospheric circulation (see Parrish and Peterson, this volume).

A dramatic change in circulation patterns occurred in late Callovian time beginning with eolian strata preserved in the Romana Sandstone (Fig. 14). Crossbedding in older eolian rocks below the Romana tends to dip toward the southeast, south, southwest or west whereas crossbedding in eolian rocks of the Romana and younger units tends to dip toward the east or northeast. The vertical sequence from the Moab Tongue of the Entrada Sandstone to the overlying Summerville Formation, which is a northern facies of the Romana, is continuous and not broken by an unconformity (Peterson, in press). Thus, although the change is readily explained by northward drift of the Colorado Plateau into a wind belt possessing different atmospheric circulation patterns, the rather abrupt aspect of the change is intriguing.

\section{Source areas}

The overall south-southwestward trend of wind patterns in the Entrada indicates that the source of the sand was to the north and that most of the sand must have been derived from the shoreline of the Sundance seaway that bordered the Entrada erg in southern Wyoming and northern Colorado. Ultimately, the sand must have been derived from some other area and moved to the southern Wyoming-northern Colorado pickup area by longshore currents. In Utah, scarce small pebbles and granules of chert in westernmost exposures of strata that correlate with the Entrada and slightly older beds suggest an ultimate source to the west. Reconnaissance crossbedding studies made on marine or mixed marine and eolian sandstone beds of the Canyon Springs Sandstone Member of the Sundance Formation in southern Wyoming 


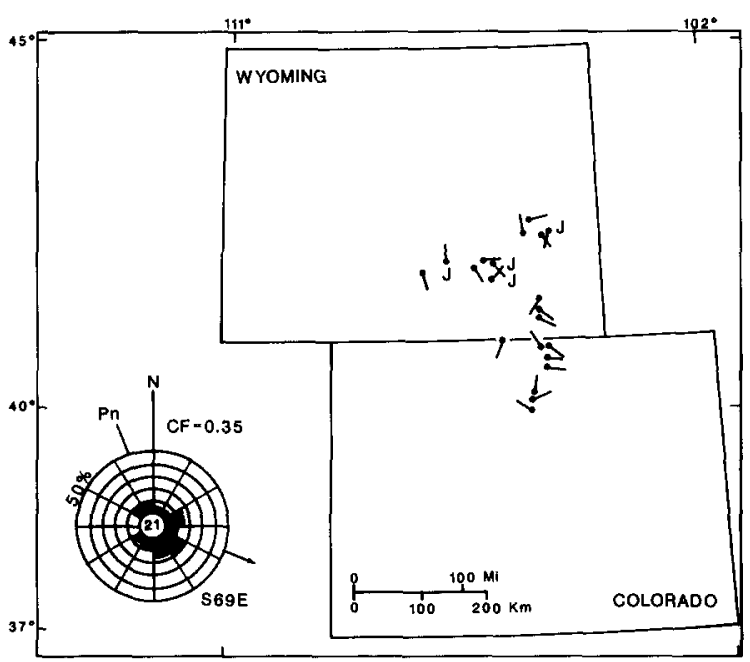

Fig. 16. Crossbedding resultants from the Canyon Springs Sandstone Member of the Sundance Formation. On the rose diagram the number of resultants used is given in the center and the arrow and bearing are of the summary resultant. $N=$ present north; $P \boldsymbol{n}=$ paleonorth; $\boldsymbol{C F}=$ consistency factor; $J=$ measurements by Jordan (1965); other measurements are by $F$. Peterson (this report).

and northern Colorado yielded highly varied crossbedding resultants that dip generally toward the southeast (Fig. 16), supporting the concept of a western source area. Moreover, studies by Hileman (1973) in the Idaho-Wyoming border area also suggest a source farther west. A small and probably inconsequential amount of sand in the Entrada was derived from the low hills in central Colorado.

\section{Late Jurassic time}

Eolian deposits of Late Jurassic age are scattered about the Western Interior where, with the exception of southern Arizona, they are either within or closely allied to the Morrison Formation (Figs. 3 and 17). The Unkpapa Sandstone in the southeastern Black Hills of South Dakota and possibly correlative beds at the base of the Morrison Formation in the northwestern Black Hills of northeastern Wyoming are at least partly eolian in origin (Szigeti and Fox, 1981) although the amount of eolian beds in the formation is unclear because the bedding structures are obscure, have been destroyed, or simply have not been described in the literature. Lenticular eolian strata are present at the base of the Morrison at many places in central Wyoming. Although they all seem to be approximately equivalent in age, they are discontinuous; no single eolian sand body extends throughout the central Wyoming area shown on the map.

Farther south on the Colorado Plateau, the Bluff Sandstone Member of the Morrison Formation and the Junction Creek Sandstone together make up the most extensive eolian sandstone unit of Late Jurassic age. A slightly smaller group of eolian beds is present farther south in the combined Recapture Member of the Morrison Formation and upper part of the Sandstone at Mesita. The precise stratigraphic relationships of the upper Mesita and the eolian facies of the Recapture are unresolved. I consider them more or less contemporaneous based on their stratigraphic position (see Condon, 1985, a, b; Condon and Peterson, 1986). Examination of outcrops and well logs indicates that the Bluff-Junction Creek and the eolian Recapture-upper Mesita do not merge in northwestern New Mexico and northeastern Arizona but, instead, are separated by an intervening facies consisting of sandstone, siltstone and mudstone.

Four small eolian deposits were found in the lower half of the Morrison west of the Four Corners in south-central Utah and north-central Arizona. Three have an outcrop length of less than $1 \mathrm{~km}$ but the westernmost one crops out for at least $16 \mathrm{~km}$ along a line of outcrops extending southeast from Escalante, Utah.

Another small unit of probable eolian origin has an extremely small outcrop distribution, being exposed over about a hundred square meters in the Canelo Hills of southern Arizona. It was included in the Rocks of Mount Hughes by Kluth (1983) but recent workers tend to include his Mount Hughes strata in the Glance Conglomerate and extend the age of the Glance from solely Early Cretaceous to Early Cretaceous and Late Jurassic (Dickinson et al., 1986). The eolian beds in the Glance are overlain by rocks that yielded an isotopic date of $151 \mathrm{Ma}$ (Kluth, 1983), which is early Tithonian in the time scale of Palmer (1983).

In addition to the Western Interior, some crossbedding data was obtained from subsurface dip- 


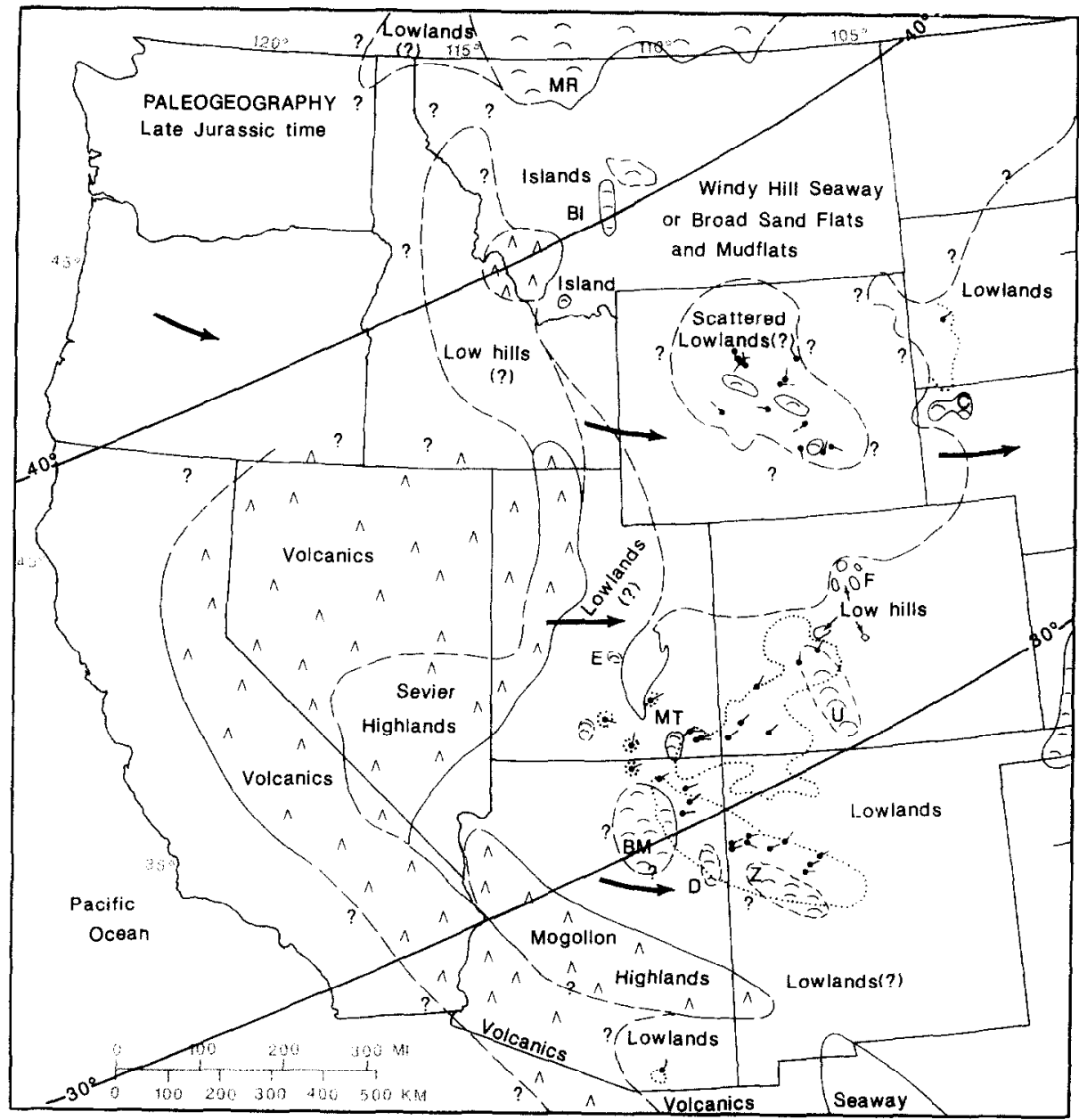

Fig. 17. Paleogeographic map for Late Jurassic time showing crossbedding resultants and paleolatitudes. Paleogeography is mainly for the early Late Jurassic (late Oxfordian Age) during the early stages of retreat of the Windy Hill seaway. Large arrows indicate predicted wind patterns from Parrish and Peterson (this volume).

meter surveys in an eolian facies of the Norphlet Formation in southern Alabama. The Norphlet is unfossiliferous and poorly dated as early Late Jurassic (middle to late Oxfordian) in age (Imlay, 1980). This determination, if correct, would make the Norphlet slightly older or equivalent in age to the Late Jurassic colianites of the Western Interior.

\section{Paleogeography}

During early Late Jurassic (late Oxfordianearly Kimmeridgian) time the Western Interior was a broad lowland area with a series of highlands or low hills separating most of it from the Pacific Ocean (Fig. 17). Following a brief period of erosion of most of the interior region, possibly related to a lowering of sea level, the Windy Hill seaway advanced southeastward briefly and then retreated across the northern part of the region from a narrow connection with the Pacific that may have existed in northwestern Montana (Imlay, 1980).

Shallow-marine deposits that record the presence of the seaway consist mostly of fossiliferous sandstone beds now incorporated in the Windy Hill Member of the Sundance Formation. Several islands are thought to have existed in western Montana (McMannis, 1965; Norwood, 1965; Peterson, 1972), more or less along the positive Belt Island trend. Imlay (1980) extends the seaway 
as far east as western North Dakota and studies by Pipiringos et al. (1969) and Pipiringos and O'Sullivan (1976, 1978) indicate that it extended south into northeastern Utah and northwestern Colorado. An evaporating basin represented by gypsum beds at the base of the Morrison Formation in the western part of southeastern Utah may have been connected with the Windy Hill seaway through narrow straits north of the San Rafael Swell.

Scattered eolian deposits are present at the base of the Morrison Formation in central Wyoming where they are closely associated with positive structures (Uhlir, 1987). The eolian beds are lenticular and do not form a continuous sheet in the area outlined on the map (Fig. 17). Rather, they probably formed as small isolated dune fields scattered about the extensive sandflats and mudflats left behind by the retreating Windy Hill seaway. Uhlir (1987) suggests that the uplifts had positive relief and therefore may have formed low hilly areas on an otherwise monotonously flat and exhumed sea bottom.

The Unkpapa Sandstone lies east of the central Wyoming eolianites and its stratigraphic position just above the Sundance Formation or the J-5 unconformity suggests that it was deposited contemporaneously with the central Wyoming beds. Isopach studies of the Unkpapa (Blakey et al., this volume), the known lenticularity of the central Wyoming eolian beds, and the relationship of the distribution of the central Wyoming beds to nearby positive structures all suggest that physical connection of the Unkpapa with the central Wyoming eolian beds across the Powder River basin in eastern Wyoming is unlikely. The Unkpapa evidently was an isolated small dune field whose distribution probably was governed, at least partly, by the Black Hills uplift. The only documented eolian beds in the formation are on the east and southeast sides (downwind) of the Black Hills uplift (Szigeti and Fox, 1981) although the bedding is obscure or has been obliterated in many other areas or has not been described adequately in the literature.

A highland area in a continental-margin magmatic arc bordered the west side of the continent and can be traced at least as far north as northern
Nevada on the basis of isotopically dated igneous rocks. Rocks of this age were later removed from the area farther north so it is not possible to document the trend of the arc in that area although northward continuation does seem likely.

The Sevier highlands in southern Nevada and western Utah lay adjacent to the magmatic arc and exposed Paleozoic and early Mesozoic sedimentary rocks. Its presence as a largely nonvolcanic terrane is indicated by provenance studies of sediment shed from this area and preserved in the Salt Wash Member of the Morrison Formation. The Salt Wash is a fluvial complex containing chert pebbles with Late Paleozoic fossils (Craig et al., 1955), indicating a source in a late Paleozoic highland sedimentary terrane that would only have been exposed to Salt Wash streams in the Sevier highlands area during the Late Jurassic.

Several areas of low hills were scattered about the south-central part of the region, on or near the Colorado Plateau. In central Colorado, Morrison strata thin and either pinch out by onlap or overlap some of the ancient hills at the sites of the ancestral Uncompahgre and Front Range uplifts (Tweto, 1957; Ward, 1957; York, 1957). Also, the northeastern part of the Bluff-Junction Creek erg extended across the northwestern part of the Uncompahgre uplift, indicating that this part of the uplift had fairly subdued topography. The westernmost part of this erg abuts the southern part of the present-day Monument uplift, which was surrounded on the north, west and south sides by Salt Wash fluvial strata (Peterson and Tyler, 1985). Evidently, Salt Wash streams were hindered from flowing east across this area by topographic relief maintained by the growing structure, thereby allowing the erg to form east (downwind) of the structure.

Another area of low hills existed in northeastern Arizona at Black Mesa uplift. Lower Morrison strata thin and pinch out by onlap against this structure although upper Morrison beds overlap it, indicating the feature had low topographic relief during deposition of older beds in the Morrison (Peterson, 1986). The Defiance and Zuni uplifts lay farther southeast in Arizona and New Mexico, respectively. Whether or not they were expressed as low hills has not been determined 
although the abundance of unconformities in Jurassic strata on the flanks of the Zuni uplift (Silver, 1948; Maxwell, 1982) suggests that it was an active structural feature and topographically high throughout most of the Jurassic. These uplifts, along with the Black Mesa uplift, seem to have played a role in determining the distribution of eolian deposits in the Recapture Member of the Morrison and the upper part of the Sandstone at Mesita. The three uplifts may have formed an interconnected series of hills of sufficient height to foster deposition of wind-blown sand and, in addition, they may have hindered streams originating in highlands farther south from crossing and destroying the dune field.

The erg represented by the combined eolian facies of the Recapture Member and the upper part of the Sandstone at Mesita lay south of and apparently was not connected to the Bluff-Junction Creek erg that lay a short distance to the north. No evidence has been found, either from surface or subsurface studies, to indicate that the two eolian deposits ever merged. Paleotectonic studies in northwestern New Mexico indicate that the axis of the Late Jurassic San Juan basin lay between the two dune fields (Santos and TurnerPeterson, 1986), and lithologies in surface outcrops or reasonably extrapolated underground through drill-hole logs suggest that the area between the two dune fields was the site of sandflats or mudflats, sabkhas, and possibly lakes or ponds. The stratigraphic and sedimentologic relationships indicate that this area was continuously downwarped and remained near the water table where there was sufficient moisture to inhibit dune formation.

In central Utah, a small area of low topographic relief coinciding with the last vestiges of the Emery uplift lay along the west side of a small embayment of the Windy Hill seaway (Fig. 17). Relief over this structure must have been low as it is small and, in Late Jurassic time, consisted of poorly lithified muds of the Summerville Formation. Finally, the westernmost small dune field in south-central Utah lies just east (downwind) of another positive structure that probably was manifested as a series of low hills (Peterson, 1984).

Eolian deposits in the Glance Conglomerate of southeastern Arizona are included in a lowland area within the Bisbee basin or structural trough. Dickinson et al (1986) tentatively extend the Bisbee trough completely across southern Arizona and into southeastern California, citing the similar age of rocks in both areas and their comparable structural setting in roughly aligned basins. On the other hand, G.B. Haxell (pers. commun., 1987) questions this and feels it is unlikely that the structural depression extended such a great distance. Enos (1983) and Salvador (1987) show a Late Jurassic seaway extending up the Chihuahua trough into south-central New Mexico and westernmost Texas. The Bisbee trough is a westward extension at the north end of the Chihuahua trough but the Bisbee is not known to contain Upper Jurassic marine strata. Bilodeau (1986) and Dickinson et al. (1986) interpret the Mogollon highlands of central Arizona as a northeastward-tilted rift shoulder that formed the northeast flank of the Bisbee rift basin.

A low hilly area in southwestern Kansas and western Oklahoma is inferred from moderately high percentages of sandstone in the Morrison Formation farther west (Peterson, 1972). The sands probably were derived from farther east as the sandstone content decreases in other directions

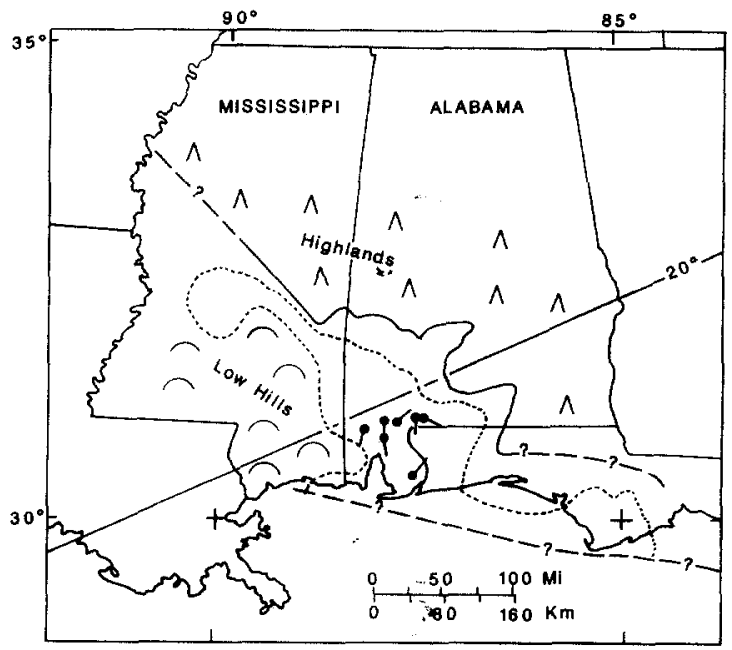

Fig. 18. Paleogeographic map for early Late Jurassic time in the eastern Gulf Coast region showing paleolatitudes and crossbedding resultants taken from subsurface dipmeter surveys. The position of the Late Jurassic shoreline (dashed line near present-day shoreline) is conjectural. 
and there is no other area known that could have been the source.

Eolian deposits in the Norphlet Formation are present in the northeastern Gulf Coast region where they extend from central Mississippi southeastward through southern Alabama and into western Florida (Fig. 18; Honda and McBride, 1981; McBride, 1981; Mitchell-Tapping, 1982; Mancini et al., 1985). They occur south of and downwind from the ancestral Appalachian highland source area that produced the coarse detritus found in the proximal or northern facies of the formation (Dinkins, 1968; Mancini et al., 1985). Another area most likely of low relief on the Wiggins arch bordered the southwestern part of the dune field (Honda and McBride, 1981; Mancini et al., 1985). Stratigraphic relationships to overlying and underlying formations indicate it was deposited during a general southward regression of marine waters, suggesting that the shoreline lay nearby and probably a short distance south of the present Gulf Coast shoreline (Mancini et al., 1985).

\section{Paleowinds}

Summary rose diagrams were constructed for three areas: (1) South Dakota and Wyoming where there is considerable variation in the resultants; (2) Arizona, Colorado, New Mexico and Utah where the resultants are much more consistent; and (3) Alabama, which is geographically isolated from the Western Interior and where only seven resultants with moderate consistency were obtained.

Eolian crossbedding in Wyoming and South Dakota yielded a summary resultant suggesting south-southwesterly winds (Fig. 15). However, the consistency factor is so low $(0.12)$ that the resultant, taken at face value, must be considered inconsistent and probably meaningless. Uhlir (1987) suggests a generally northward direction of transport based on grouping the outcrops and set-by-set analysis (D.M. Uhlir, pers. commun., 1986), which is consistent with resultants obtained from other parts of the Western Interior. He further offers that the complex wind patterns may have been significantly influenced by proximity of the Windy Hill seaway. The seaway may well have had a far more complexly indented shoreline than that shown on the paleogeographic map (Fig. 17), but detailed stratigraphic and sedimentologic studies that might reveal this have yet to be made.

Crossbedding resultants from Arizona, Colorado, New Mexico and Utah have a consistency factor of 0.89 , reflecting considerably less dispersion than eolian units farther north (Fig. 15). West-southwesterly winds, or westerly winds in terms of past coordinates, are indicated. The unimodal character of the rose diagram is striking when the fairly complex paleogeography is taken into consideration. A small embayment of the Windy Hill seaway extended southward well into the region, low hilly areas were fairly common, and highlands or possibly mountainous terranes were present upwind to the northwest, west and south. The single resultant in southeastern Arizona has a more northerly trend than most of those obtained from eolian sandstones on the Colorado Plateau. However, considering the variation inherent to wind systems, it is not significantly different from resultants farther north on the Colorado Plateau. Evidently, the varied geographic character of the Colorado Plateau region and surrounding areas exerted little influence on circulation patterns over the dune fields. At least, no consistent deviation in wind patterns that might be attributed to geographic factors is evident.

Only seven resultants obtained from subsurface dipmeter surveys are available from southern Alabama in the eastern Gulf Coastal region (Fig. 15). These yield a summary resultant dipping to the southeast, suggesting northwesterly winds in terms of paleocoordinates. Statistical analysis of these yielded a moderate consistency factor of 0.51. The rose diagram has a multimodal aspect and, although the summary resultant probably is representative of the general trend of the wind patterns, more data would be desirable.

In summary, resultants obtained from Upper Jurassic eolian rocks in the southern part of the Western Interior show an overall northeastward trend (Fig. 15). Resultants from farther north in the Wyoming-South Dakota part of the Western Interior are highly varied and show no consistent trend. 


\section{Source areas}

Enough is known about the sedimentology of the region to be fairly certain about the source of sand in the various Late Jurassic dune fields of the Western Interior and Gulf Coast. In all cases, the source was nearby and probably from reworking of fluvial or marine deposits.

Uhlir (1987) suggests that eolian sand in central Wyoming was derived from nearby positive areas adjacent to the dune fields. The sand evidently came from marine sands in the Windy Hill Member of the Sundance Formation, which were exposed during retreat of the Windy Hill seaway, or by local uplifts, and subsequently reworked and concentrated by eolian processes.

The Unkpapa Sandstone had a similar origin although in this case the nearby uplift may have been the Chadron arch in northwestern Nebraska (Szigeti and Fox, 1981). The sand may have been transported northward by streams where it was reworked by the wind, or it may have been carried northwestward by streams to the edge of the Windy Hill seaway where it was moved northward by shoreline currents and subsequently blown inland (eastward), to accumulate downwind from the Black Hills uplift. An alternative possibility is that sands on the western and northern flanks of the Black Hills uplift that may have been in the Windy Hill Member were reworked by the wind and carried a short distance to accumulate in low-lying areas on the eastern and southeastern flanks of the uplift.

Sand in the Bluff-Junction Creek erg was derived from the beds of Salt Wash streams that flowed around the north, west, and south sides of the southern Monument uplift (Peterson and Tyler, 1985). Salt Wash streams tapped sediment sources farther west in the highlands of southern Nevada and western Utah.

Eolian sand in the Recapture-upper Mesita erg may have been derived from eroded beds of Middle Jurassic eolian strata exposed in northwestern and north-central Arizona. It is also possible that the sand could have come from the beds of streams that flowed out of highlands farther southwest and west.

The small dune field just east of the small marine(?) embayment in southeastern Utah prob- ably was reworked from subaqueous sand originally deposited in the embayment that was exposed during retreat of the Windy Hill sea. Of the three other small dune fields farther southwest, one lies downwind from a positive structure and the other two are not related to any known structural feature but lie embedded within fluvial sandstones of the Salt Wash Member of the Morrison Formation. The source of sand for all three probably was nearby Salt Wash stream deposits and their preservation may have been determined by little else than lack of lateral migration of the streams across the fledgling dune fields.

The small dune field in southern Arizona is represented by clean, well-sorted, crossbedded sandstone beds encased in thick, poorly sorted, fluvial sandstone that contains clasts of igneous rocks as much as $0.5 \mathrm{~m}$ in diameter. Undoubtedly, this was another short-lived eolian deposit preserved by the whims of shifting, high-energy streams. The eolian sand was almost undoubtedly derived from nearby stream beds.

Late Jurassic dune fields tend to lie downwind from positive structural elements, but they also occur where these elements diverted contemporaneous streams and shielded the dune fields from their destructive influence. In most cases, especially the Bluff-Junction Creek erg, the structures are so slight that it does not appear possible for them to have been the source of the sand. A source from nearby stream beds or reworking of sands initially deposited in marine waters is the most reasonable explanation for the origin of these deposits. In these cases, the uplifts appear to have provided the wind shadows that facilitated accumulation of the eolian deposits.

\section{Summary and conclusions}

Crossbedding resultants obtained from eolian sandstones of Pennsylvanian to Jurassic age reflect the evolution of atmospheric circulation patterns across the western United States. Pennsylvanian to about middle Middle Jurassic winds blew generally toward the southwest, south, or southeast (present coordinates) whereas late Middle and Late Jurassic winds blew toward the northeast (Fig. 14). 
The timing of the late Middle Jurassic change in circulation patterns can be determined from the fairly abundant eolian units on the Colorado Plateau. The change occurred in late Middle Jurassic time between deposition of the Entrada Sandstone of Middle Callovian age and the Romana Sandstone of Late Callovian age (Fig. 14). The change appears to have occurred progressively and in a counterclockwise fashion if the anomalous westward-oriented summary resultant from the Moab Tongue of the Entrada is disregarded. Thus, crossbedding resultants in the Entrada indicate winds that blew southwestward during deposition of the lower part of the formation to southeastward during deposition of the upper part (upper and Cow Springs Members). In the younger Romana Sandstone they blew about due east whereas resultants in the overlying Morrison and related units indicate winds that blew toward the northeast. The counterclockwise change in wind patterns reflects passage of the Western Interior through different parts of the circulation system during poleward perambulations of the continent rather than orographic effects (Parrish and Peterson, this volume).

Summary resultants obtained from the Moab Tongue of the Entrada indicate winds that blew to the west. Although they dip consistently westward, these resultants are at odds with all other summary resultants obtained from this study (Fig. 14). No reason is apparent for this anomaly although it may be related to the position of the Moab dune field at the edge of the Middle Jurassic seaway where anomalous circulation patterns may have developed.

Eolian sandstone beds that fall within the time-framework of this study are currently known in only a few geographically separated rock units in eastern North America-the Upper Triassic Wolfville Formation and associated rocks in Nova Scotia and the Upper Jurassic Norphlet Formation of the eastern Gulf Coast region. The Wolfville was deposited by east-northeasterly winds (Fig. 10) and the Norphlet was deposited by northwesterly winds (Figs. 15 and 18).

The influence of paleogeography on atmospheric circulation patterns was somewhat different than anticipated. Except for relatively minor details, major topographic features such as highlands did not seem to produce consistent deflections in wind patterns. The greatest geographic influence on circulation was found at shorelines, especially highly indented shorelines, where temperature differences associated with land-sea contrasts in atmospheric heating may produce highly variable winds. However, this interpretation must be qualified by the nature of the data. In some of these cases there is a question about how the data were obtained and whether it came from purely eolian beds or from sandstones that may have been reworked by marine currents during an advance of the shoreline over the seaward part of the dune field.

Perhaps the most significant finding from the paleogeographic studies is that a surprisingly small and low topographic high is all that may be needed to foster development of a dune field. Of course, the climate must be favorable, adequate quantities of sand must be available, and streams that might overwhelm the nascent dune field must not be present although streams may be nearby and provide the source of the dune sand.

\section{Acknowledgements}

A large number people were helpful in the many aspects of preparing this report. Charles Copeland helped in obtaining dipmeter logs and other subsurface information in southern Alabama. E.K. Maughan was a storehouse of information for the late Paleozoic, knowing who had unpublished data or where useful unpublished theses and dissertations were. His guidance was invaluable in interpreting the late Paleozoic and Mesozoic in the northern part of the Western Interior. N.J. Silberling provided the location of the eolian(?) Lower Jurassic quartzites in western Nevada and C.F. Kluth furnished the location of the Upper Jurassic eolian deposit in the Canelo Hills of southern Arizona. The following people kindly contributed unpublished crossbedding or other data that were helpful in the compilations: J.A. Campbell, V.L. Freeman, S.G. Fryberger, S.Y. Johnson, D.R. Kerr, S.J. Lindquist, J.E. Marzolf, E.K. Maughan, M.L. Porter, H.I. Saperstone, J.D. Stanesco, C.E. Turner-Peterson, and D.M. Uhlir. 
In addition, R.L. Blakey, D. Boyd, R.J. Hite, E.K. Maughan, N.J. Silberling and J.R. Steidtmann helped in discussing or reviewing the paleogeographic maps. The manuscript was critically reviewed by E.K. Maughan and C.J. Schenk. The need for a systematic documentation of crossbed- ding studies for interpreting paleowind circulation patterns over the large dune fields of the U.S. was recognized initially by Gary Kocurek, whose patience, good-natured goading, and enthusiastic support aided immeasurably in carrying this report on to completion.

\section{Appendix}

Sources of crossbedding data are listed with the following maps, which also give the names of the stratigraphic units that were studied.

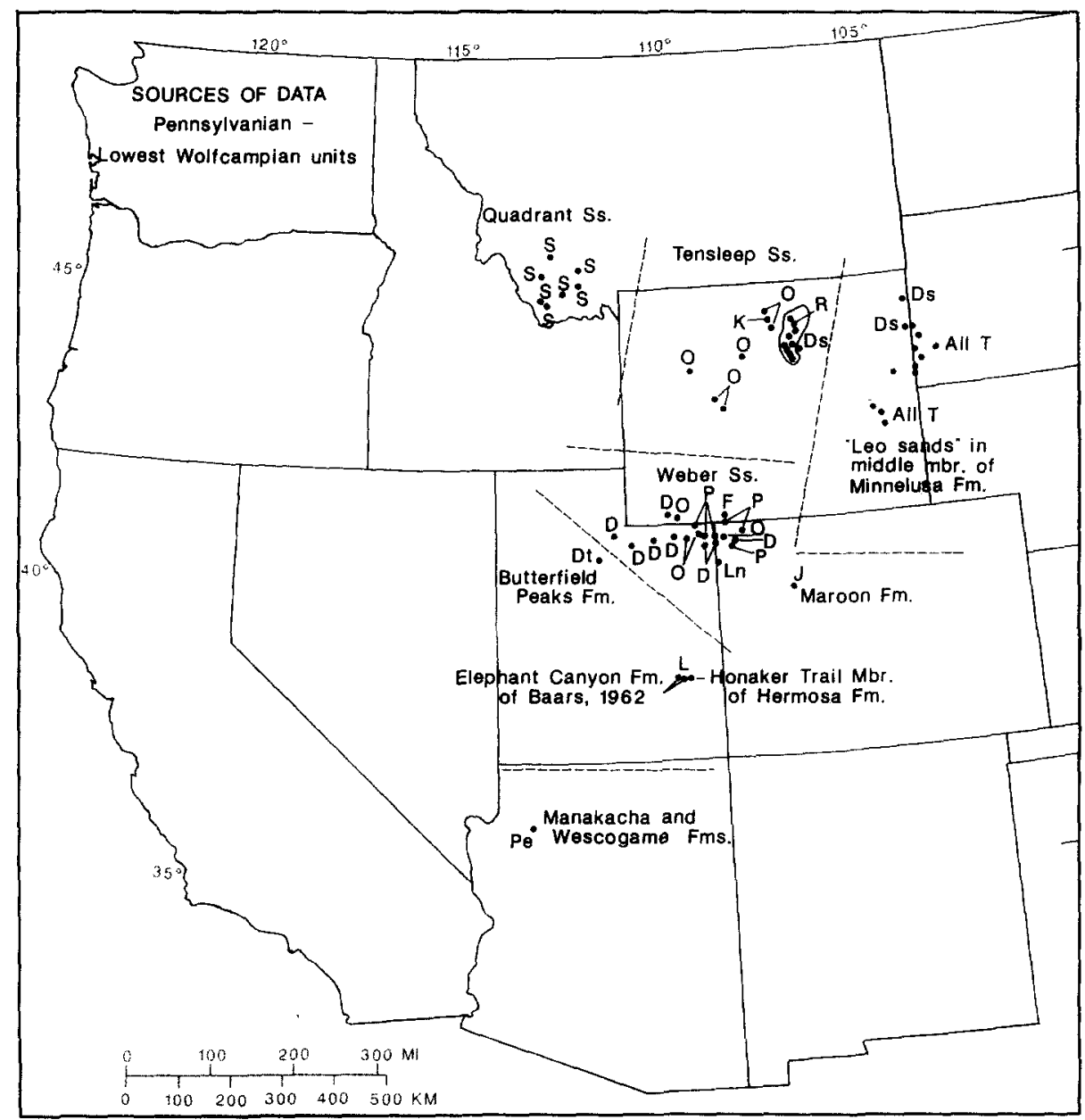

Fig. 19. Sources of crossbedding data for Pennsylvanian to lowermost Wolfcampian strata showing names of stratigraphic units. $D=$ Doe (1973); $D s=$ Desmond et al. (1984); $D t=$ Driese and Dott (1984); $F=$ Fryberger (1979); $J=$ Johnson (1987b); $K=$ Kerr and Dott, this volume; $L=$ Loope (1981); $L n=$ Larson (1975); $O=$ Opdyke and Runcorn (1960); $P=P o o l e(1962) ; P e=F$. Peterson, this report; $R=$ Rittersbacher (1985); $S=$ Saperstone and Ethridge (1984) and H.I. Saperstone, pers. commun. (1986); $T=$ Tromp et al. (1981). 


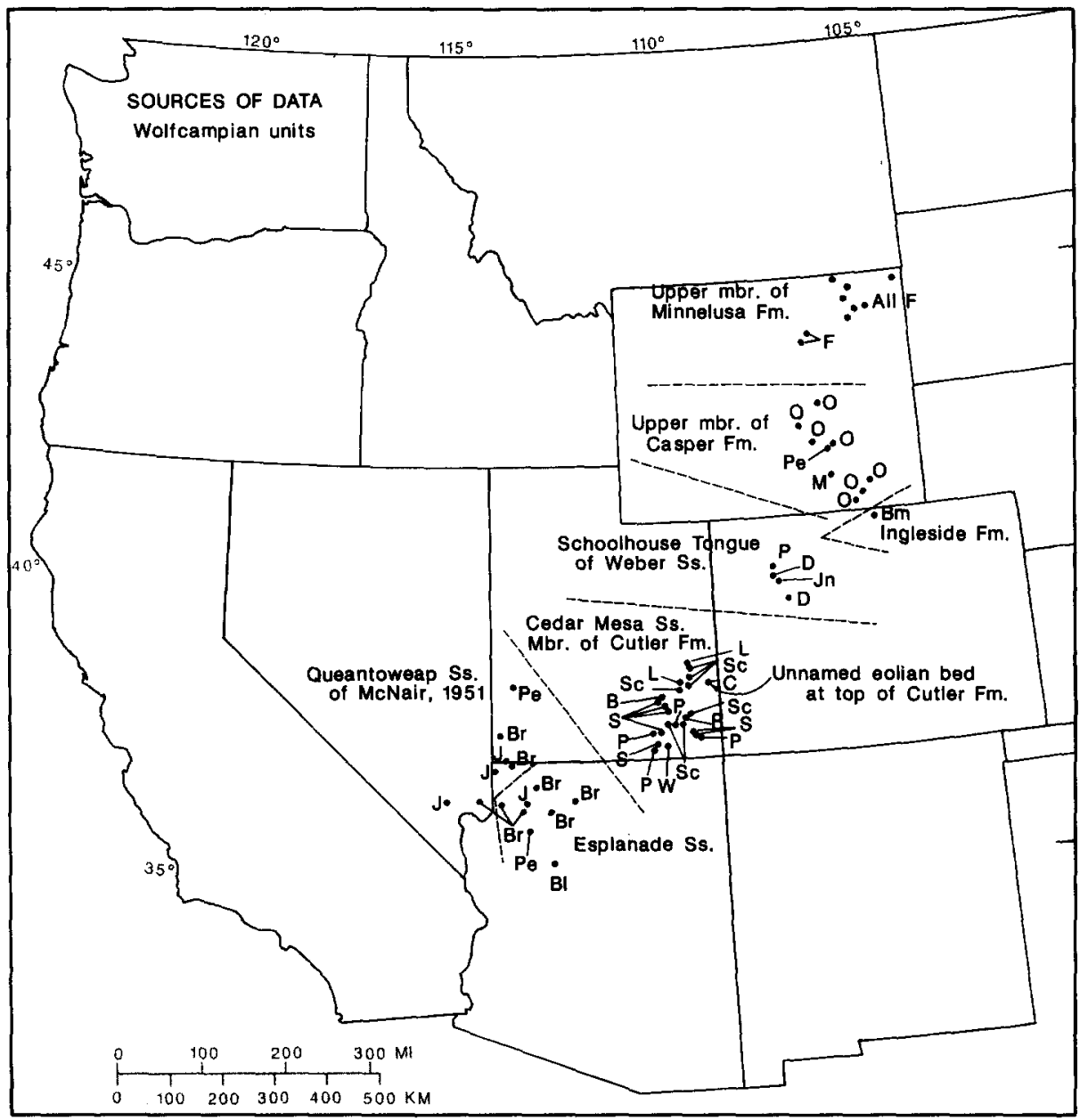

Fig. 20. Sources of crossbedding data for Wolfcampian strata showing names of stratigraphic units. $B=B a a r s(1961) ; B l=B l a k e y$ (1979); $B m=$ Berman (1978); $B r=$ Brill (1963); $C=$ Campbell and Steele-Mallory (1979); $D=$ Doe (1973); $F=$ Fryberger (1979); $J=$ Johanson (1981); $J_{n}=$ Johnson, (1987b); $L=$ Loope (1981); $M=$ E.K. Maughan, pers. commun. (1986); $O=O p d y k e$ and Runcorn (1960); $P=$ Poole (1962); $P e=$ F. Peterson, this report; $R=$ Reiche (1938); $S=$ Stewart et al. (1956); $S c=J . D$. Stanesco and J.A. Campbell, pers. commun. (1986); $W=$ Read and Wanek (1961). 


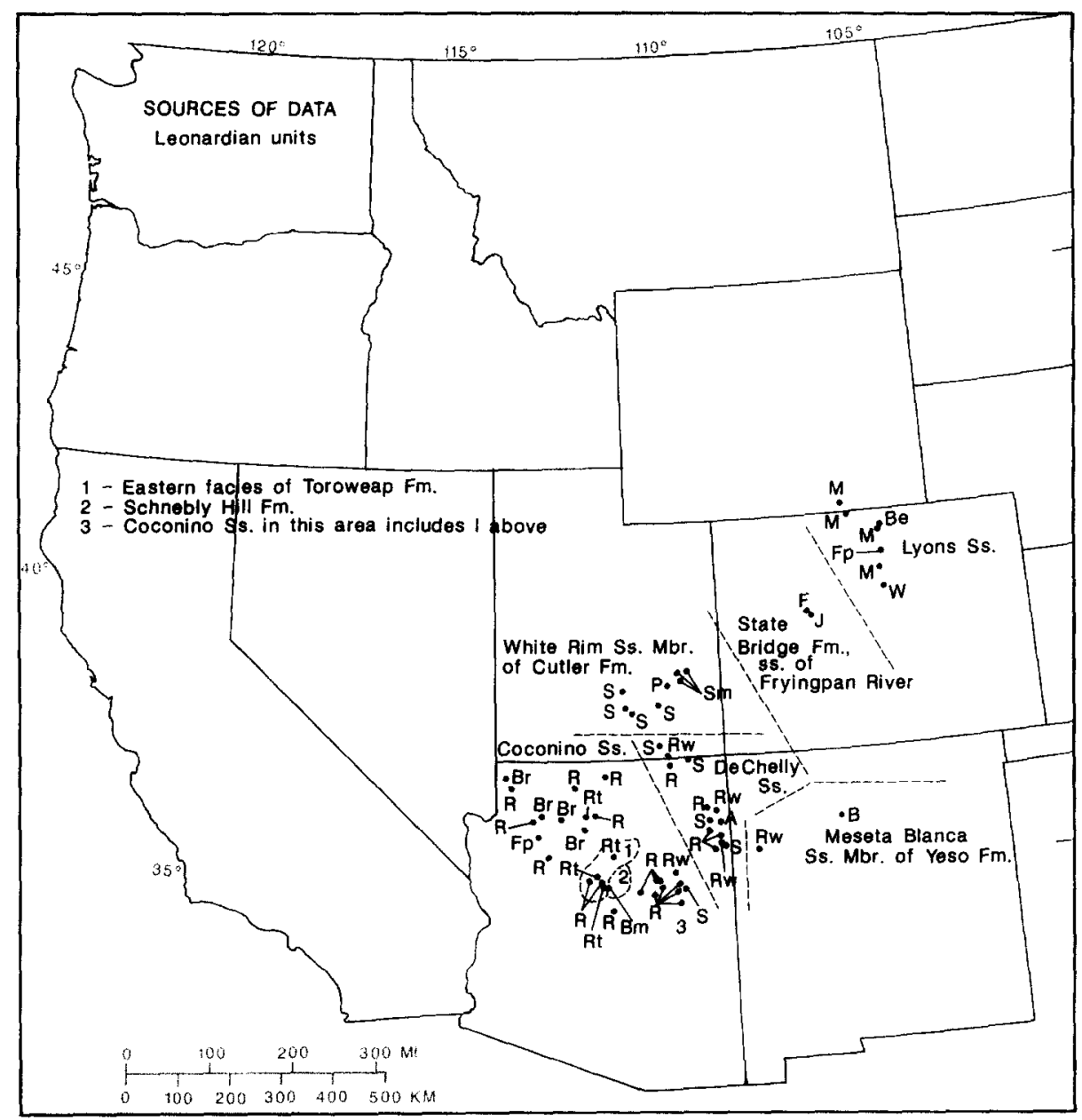

Fig. 21. Sources of crossbedding data for Leonardian strata showing names of stratigraphic units. $A=$ Allen and Balk (1954); $B=$ Baars (1961); $B e=$ Berman (1978); $B m=$ Blakey and Middleton (1983); $B r=$ Brill (1963); $F=$ V.L. Freeman, pers. commun. (1986); $F p=$ F. Peterson, this report; $J=$ Johnson (1987b); $M=$ E.K. Maughan (1966) and pers. commun. (1986); $P=$ Poole (1962); $R=$ Reiche (1938); $R t=$ Rawson and Turner (1979) and C.E. Turner-Peterson, pers. commun. (1986); $R w=R e a d$ and Wanek (1961); $S=$ Stewart et al. (1956); $S m=$ Steele-Mallory (1982); $W=$ Weimer and Erickson (1976). 


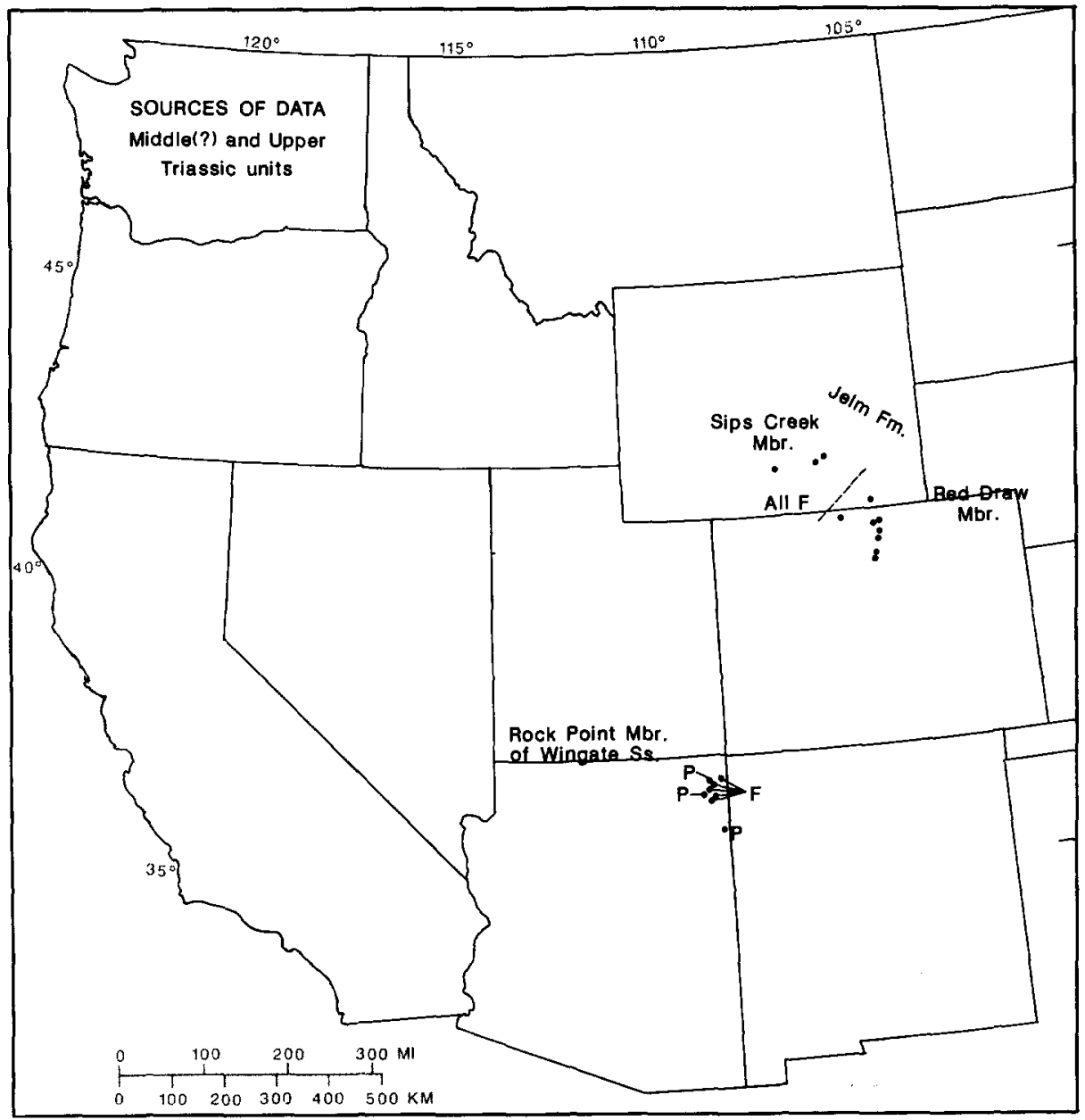

Fig. 22. Sources of crossbedding data for Middle(?) and Upper Triassic strata showing names of stratigraphic units. $F=F$. Peterson, this report; $P=$ Poole (1962). 


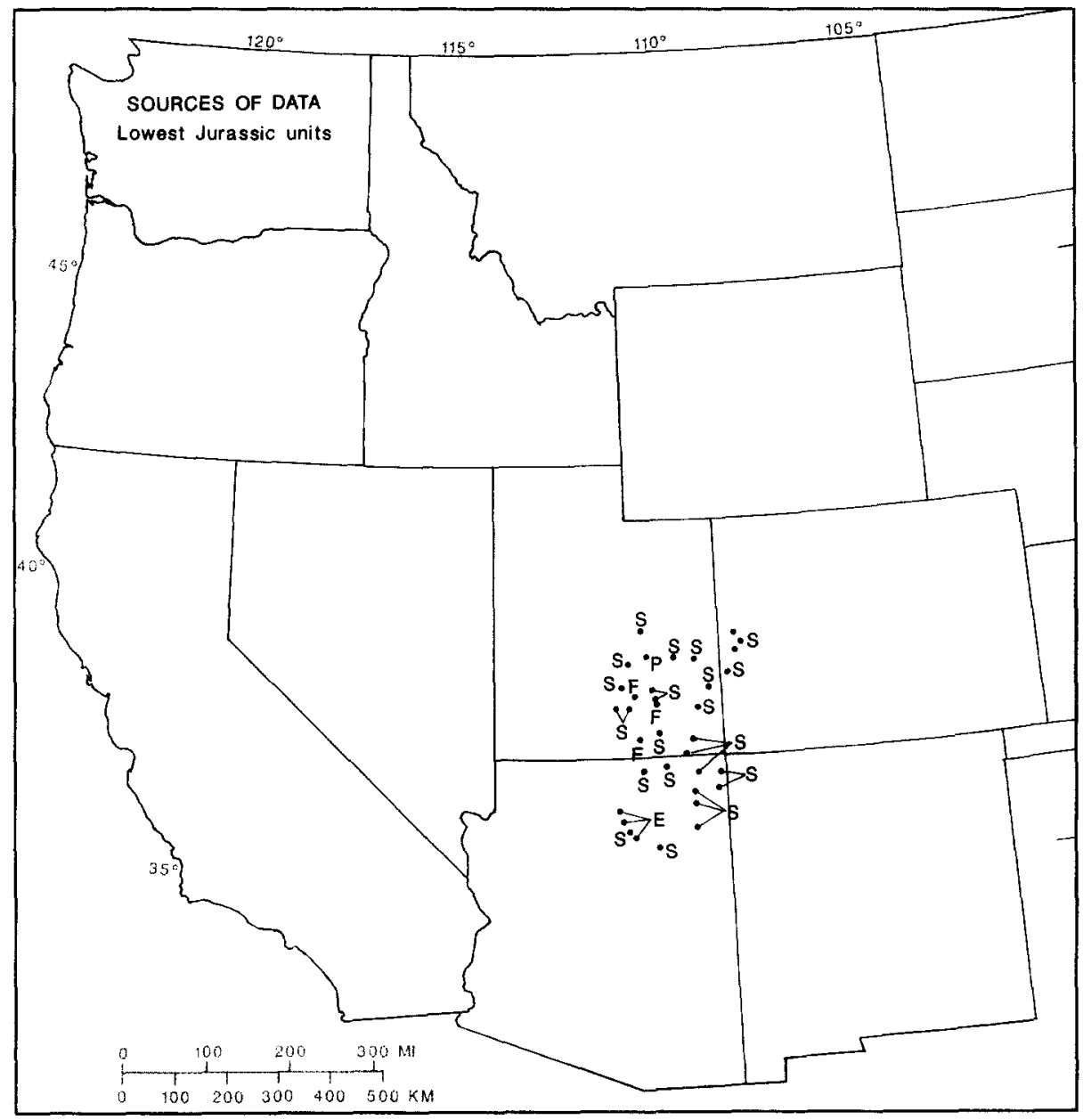

Fig. 23. Sources of crossbedding data for lowermost Jurassic strata. All measurements are from the Lukachukai Member of the Wingate Sandstone. $E=$ Edwards (1985); $F=F$. Peterson, this report; $P=$ Poole (1962); $S=$ Stewart et al. (1956). 


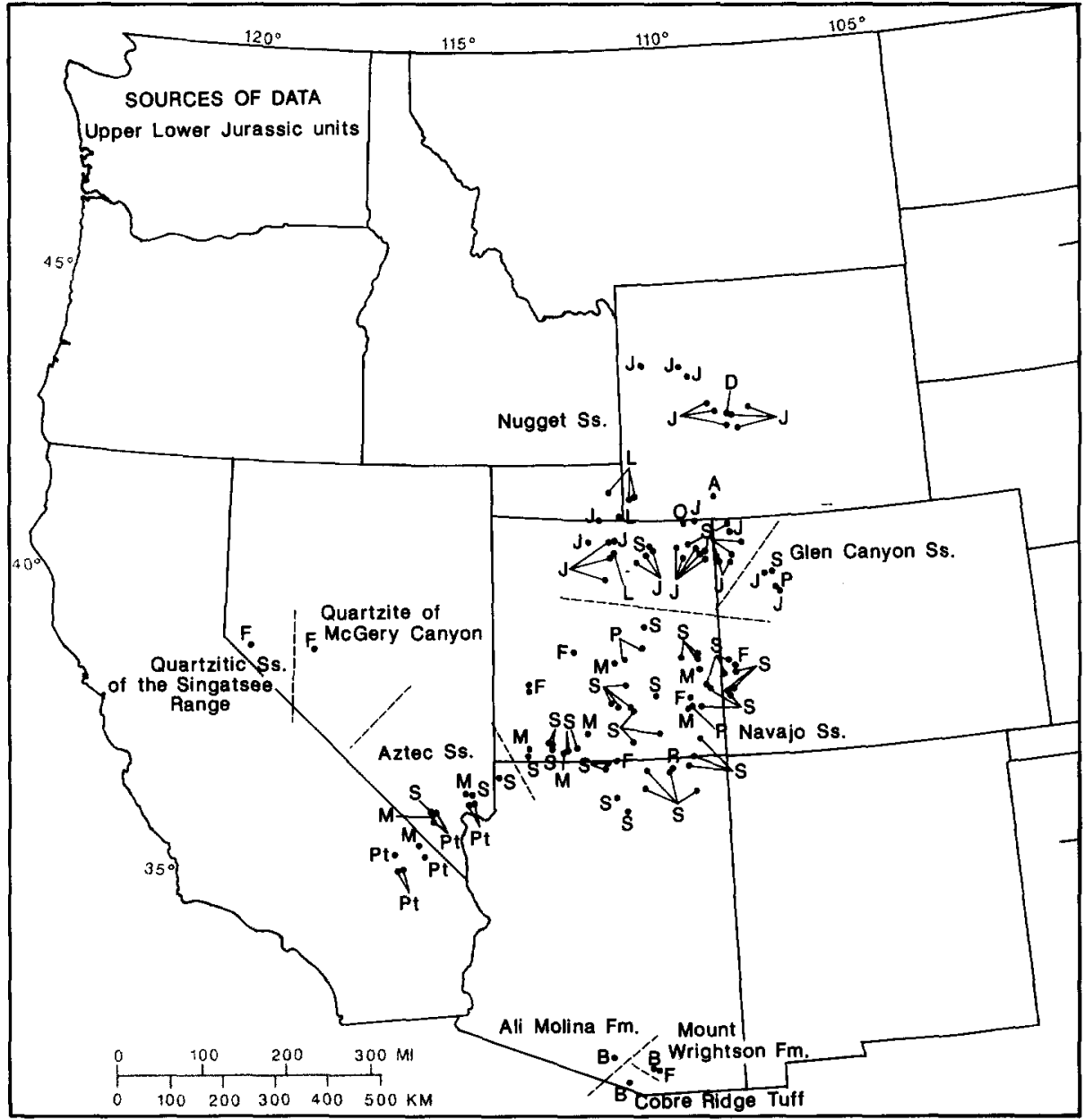

Fig. 24. Sources of crossbedding data for upper Lower Jurassic strata showing names of stratigraphic units. $A=L$ upe and Ahlbrandt (1979); $B=$ Bilodeau and Keith (1986); $D=$ Doelger and Steidtmann (1985); $F=F$. Peterson, this report; $J=J o r d a n(1965)$; $L=$ S.J. Lindquist (1983), pers. commun. (1986), and this volume; $M=$ Marzolf (1983a), pers. commun. (1986), and this volume; $O=$ Opdyke and Runcorn (1960); $P=$ Poole (1962); $P t=$ Porter (1985); $R=$ Reiche (1938); $S=$ Stewart et al. (1956). 


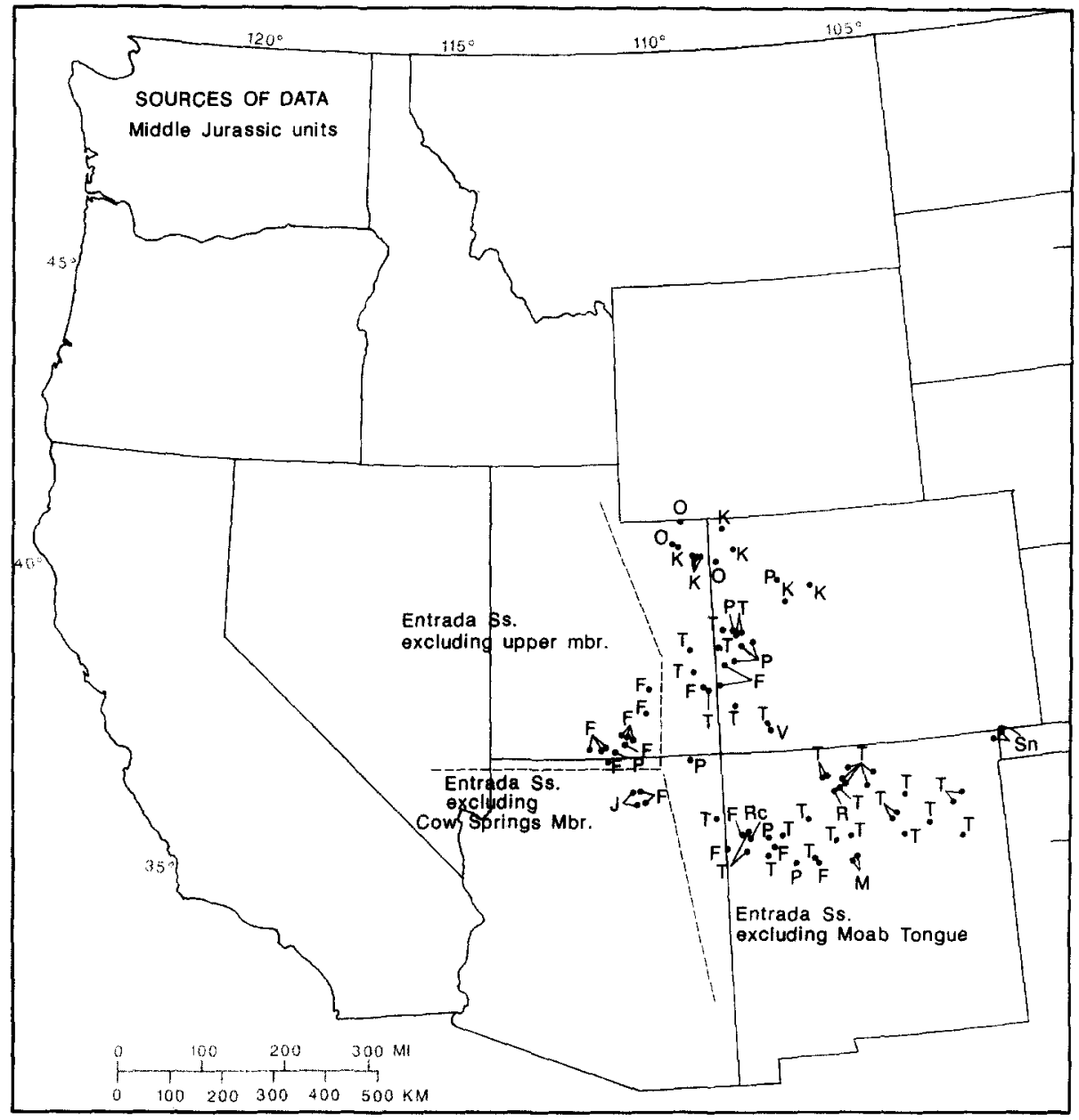

Fig. 25. Sources of crossbedding data for Middle Jurassic strata showing names of stratigraphic units. $F=F$. Peterson, this report; $J=$ Johnston (1975); $K=$ Kocurek (1981); $M=$ Moench and Schlee (1967); $O=$ Otto and Picard (1975); $P=$ Poole (1962); $R=$ Reese (1984); $R c=$ Reiche ("type Wingate Sandstone" of 1938 report, Entrada Sandstone of present terminology); $T=$ Tanner (1965); $V=$ Ver Hoeve (1982); $W=$ Jordan (1965). 


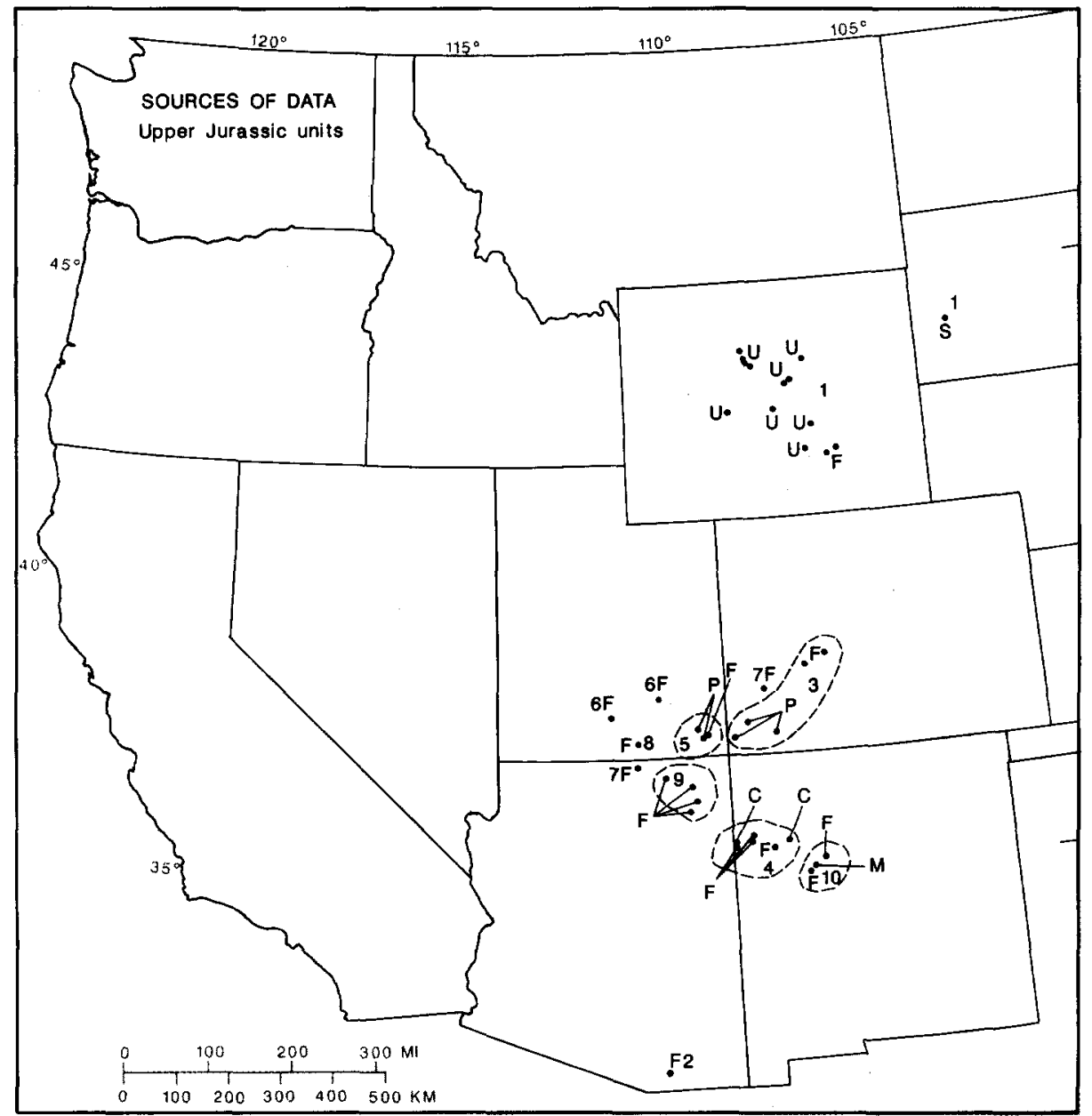

Fig. 26. Sources of crossbedding data for Upper Jurassic strata showing names of stratigraphic units. $C=$ Condon (1985ab); $F=F$. Peterson, this report; $M=$ Moench and Schlee (1967); $P=$ Poole (1962); $S=$ Szigeti and Fox (1981); $U=$ D.M. Uhlir, pers. commun. (1986).

Stratigraphic units: $l=$ Unkpapa Sandstone (South Dakota) or central Wyoming eolian sandstones at the base of the Morrison Formation. 2 = Eolian beds in the Glance Conglomerate (Rocks of Mount Hughes of Kluth, 1983). $3=$ Junction Creek Sandstone. 4 = Eolian facies of the Recapture Member of Morrison Formation. 5= Bluff Sandstone Member of the Morrison Formation. $6=$ Local eolian beds in the Tidwell Member of the Morrison Formation. $7=$ Local eolian bed in the lower part of the Salt Wash Member of the Morrison Formation, $8=$ Local eolian bed in the upper part of the Salt Wash Member of the Morrison Formation. $9=$ Local eolian beds in the upper part of the Recapture Member of the Morrison Formation. $10=$ Upper part of the Sandstone at Mesita. 


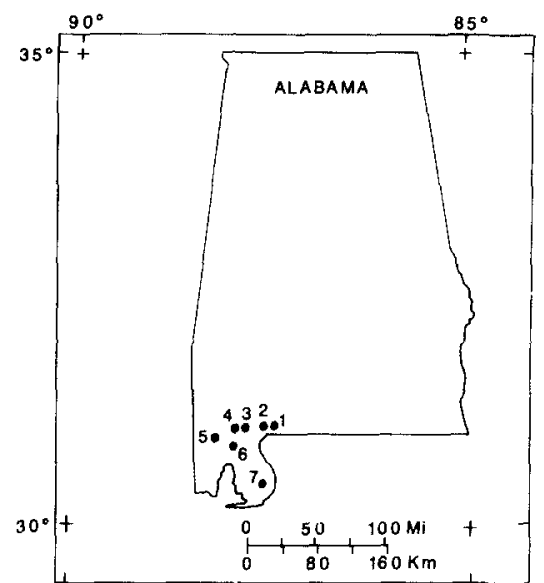

Fig. 27. Wells with dipmeter surveys through the Upper Jurassic Norphlet Formation in the eastern Gulf Coast region used in compiling Fig. 18. $I=$ Hughes Eastern Pet. Ltd; No. 1 AticNorthrup Estate 32-3; Sect. 32, T. 2 N., R. 8 E., Escambia Co., Alabama. 2 = Hughes Eastern Pet. Ltd.; No. 1 Cunningham 34-4; Sect. 34, T. 2 N., R. 7 E., Escambia Co., Alabama. $3=$ Woods Pet. Corp. and Anderson Interests; No. 1 Container Corp.; Sect. 28, T. 2 N., R. 4 E., Baldwin Co., Alabama. 4 = Chevron-Shell et al.; No. 1 J.A. Bryars Unit No. 1; Sect. 47, T. 1 N., R. 2 E., Baldwin Co., Alabama. $5=$ Getty Oil Co.; Peter Klein 3-14 No. 1; Sect. 3, T. 2 S., R. 1 W., Mobile Co., Alabama. $6=$ Amoco Prod. Co.; No. 1 South Middle River; Sect. 13, T. 2 S., R. 1 E., Baldwin Co., Alabama. $7=$ Phillips Pet. Co.; No. 1 International Paper "A"; Sect. 32, T. 6 S., R. 6 E., Baldwin Co., Alabama.

\section{References}

Achauer, C.W., 1987. Marine carbonate embayment system in an eolian dune terrain, Permian upper Minnelusa Formation, Rozet area, Powder River basin, Wyoming. Bull. Am. Assoc. Pet. Geol., 71: 524.

Agatston, R.S., 1954. Pennsylvanian and Lower Permian of northern and eastern Wyoming. Bull. Am. Assoc. Pet. Geol., 38: 508-583.

Allen, J.E. and Balk, R., 1954. Mineral resources of Fort Defiance and Tohatchi quadrangles, Arizona and New Mexico. N.M. Inst. Min. Tech. Bull., 36: 192 pp.

Allmendinger, R.W, and Jordan, T.E., 1981. Mesozoic evolution, hinterland of the Sevier orogenic belt. Geology, 9: 308-313.

Anderson, T.H. and Schmidt, V.A., 1983. The evolution of Middle America and the Gulf of Mexico-Caribbean Sea region during Mesozoic time. Geol. Soc. Am. Bull., 94: 941-966.

Armstrong, R.L. and Suppe, J., 1973. Potassium-argon geochronology of the Mesozoic igneous rocks in Nevada, Utah, and southern California. Geol. Soc. Am. Bull., 84: 1375-1392.
Ash, S.R., 1972. Plant megafossils of the Chinle Formation. In: C.S. Breed and W.J. Breed (Editors), Investigations in the Triassic Chinle Formation. Mus. North. Ariz. Bull., 47: 23-44.

Baars, D.L., 1961. Permian blanket sandstones of the Colorado Plateau. In: J.A. Peterson and J.C. Osmond (Editors), Geometry of Sandstone Bodies. Am. Assoc. Pet. Geol., Tulsa, Okla., pp. 179-207.

Baars, D.L., 1962. Permian system of the Colorado Plateau. Bull. Am. Assoc. Pet. Geol., 46: 149-218.

Baars, D.L., 1987. The Elephant Canyon Formation revisited. In: J.A. Campbell (Editor), Geology of Cataract Canyon and Vicinity. Four Corners Geol. Soc. Guidebook, 10th Field Conf., pp. 81-90.

Berman, A.E., 1978. Permian stratigraphy and paleotectonics, Bellvue-Livermore area, Larimer County, Colorado-relation to petroleum in the Lyons Formation. M.S. Thesis, Colorado School of Mines, Golden, Colo., No. 2036, 86 pp. (unpublished).

Bilodeau, W.L., 1986. The Mesozoic Mogollon highlands, Arizona - an Early Cretaceous rift shoulder. J. Geol., 94: $724-735$.

Bilodeau, W.L. and Keith, S.B., 1986. Lower Jurassic Navajo-Aztec-equivalent sandstones in southern Arizona and their paleogeographic significance. Bull. Am. Assoc. Pet. Geol, 70: 690-701.

Bissell, H.J., 1969. Permian and Lower Triassic transition from the shelf to basin (Grand Canyon, Arizona to Spring Mountains, Nevada). In: D.L. Baars (Editor), Geology and Natural History of the Grand Canyon Region. Four Corners Geol. Soc. Guidebook, 5th Field Conf., pp. 135-169.

Blakey, R.C., 1974. Stratigraphic and depositional analysis of the Moenkopi Formation, southeastern Utah. Utah Geol. Min. Surv. Bull., 104: 81 pp.

Blakey, R.C., 1979. Lower Permian stratigraphy of the southern Colorado Plateau. In: D.L. Baars (Editor), Permianland. Four Corners Geol. Soc. Guidebook, 9th Field Conf., pp. 115-129.

Blakey, R.C., 1980. Pennsylvanian and Early Permian paleogeography, southern Colorado Plateau and vicinity. In: T.D. Fouch and E.R. Magathan (Editors), Paleozoic Paleogeography of the West-Central United States. Rocky Mountain Sect., Soc. Econ. Paleontol. Mineral., pp. 239-257.

Blakey, R.C., 1988. Basin tectonics and erg responses. In: G. Kocurek (Editor), Late Paleozoic and Mesozoic Eolian Deposits of the Western Interior of the United States. Sediment. Geol., 56: 127-151 (this volume).

Blakey, R.C. and Gubitosa, R., 1984. Controls of sandstone body geometry and architecture in the Chinle Formation (Upper Triassic), Colorado Plateau. Sediment. Geol., 38: 51-86.

Blakey, R.C. and Middleton, L.T., 1983. Permian shoreline eolian complex in central Arizona-dune changes in response to cyclic sealevel changes. In: M.E. Brookfield and T.S. Ahlbrandt (Editors), Eolian Sediments and Processes. 
(Developments in Sedimentology, 38) Elsevier, Amsterdam, pp. 551-581.

Blakey, R.C., Peterson, F. and Kocurek, G., 1988. Synthesis of late Paleozoic and Mesozoic eolian deposits of the Western Interior of the United States. In: G. Kocurek (Editor), Late Paleozoic and Mesozoic Eolian Deposits of the Western Interior of the United States. Sediment. Geol., 56: 3-125 (this volume).

Bohannon, R.G., 1983. Mesozoic and Cenozoic tectonic development of the Muddy, North Muddy, and northern Black Mountains, Clark County, Nevada. In: D.M. Miller, V.R. Todd and K.A. Howard (Editors), Tectonic and Stratigraphic Studies in the Eastern Great Basin. Geol. Soc. Am. Mem., 157: 125-148.

Brill Jr., K.G., 1963. Permo-Pennsylvanian stratigraphy of western Colorado Plateau and eastern Great Basin regions. Geol. Soc. Am. Bull., 74: 307-330.

Bryant, B., McGrew, L.W. and Wobus, R.A., 1981. Geologic map of the Denver $1^{\circ} \times 2^{\circ}$ quadrangle, north-central Colorado. U.S. Geol. Surv., Misc. Invest. Series, Map I-1163: 1: 250,000 .

Burchfiel, B.C. and Davis, G.A., 1981. Mojave Desert and environs. In: W.G. Ernst (Editor), The Geotectonic Development of California, Rubey Volume 1. Prentice-Hall, Englewood Cliffs, N.J., pp. 217-252.

Campbell, J.A., 1987. Stratigraphy and depositional facies; Elephant Canyon Formation. In: J.A. Campbell (Editor), Geology of Cataract Canyon and Vicinity. Four Corners Geol. Soc. Guidebook, 10th Field Conf., pp. 91-98.

Campbell, J.A. and Steele-Mallory, B.A., 1979. Uranium in the Cutler Formation, Lisbon Valley, Utah. In: D.L. Baars (Editor), Permianland. Four Corners Geol. Soc. Guidebook, 9th Field Conf., pp. 23-32.

Carter, J.N., Luyendyk, B.P. and Terres, R.R., 1987. Neogene clockwise tectonic rotation of the eastern Transverse Ranges, California, suggested by paleomagnetic vectors. Geol. Soc. Am. Bull., 98: 199-206.

Casey, J.M., 1980. Depositional systems and paleogeographic evolution of the late Paleozoic Taos trough, northern New Mexico. In: T.D. Fouch and E.R. Magathan (Editors), Paleozoic Paleogeography of the West-Central United States. Rocky Mountain Sect., Soc. Econ. Paleontol. Mineral., pp. 181-196.

Clemons, R.E., 1980. The geologic past. In: R.E. Clemons, P.W. Christiansen and H.L. James (Editors), Scenic Trips to the Geologic Past, No. 10. N.M. Bur. Mines Miner. Resour., pp. 13-23.

Condon, S.M., 1985a. Lithologic descriptions of selected intervals of Jurassic rocks in southeastern Utah, northeastern Arizona, and northwestern New Mexico. U.S. Geol. Surv., Open-File Rep., 85-223: 100 pp.

Condon, S.M., 1985b. Lithologic descriptions of selected Middle and Upper Jurassic rocks from Gallup to Laguna in northwestern New Mexico. U.S. Geol. Surv., Open-File Rep., 85-126: 68 pp.

Condon, S.M. and Peterson, F., 1986. Stratigraphy of Middle and Upper Jurassic rocks of the San Juan basin-historical perspective, current ideas, and remaining problems. In: C.E. Turner-Peterson, E.S. Santos and N.S. Fishman (Editors), A Basin Analysis Case Study - The Morrison Formation, Grants Uranium Region, New Mexico. Am. Assoc. Pet. Geol., Stud. Geol., 22: 7-26.

Craig, L.C., Holmes, C.N., Cadigan, R.A., Freeman, V.L., Mullens, T.E. and Weir, G.W., 1955. Stratigraphy of the Morrison and related formations, Colorado Plateau region -a preliminary report. U.S. Geol. Surv. Bull., 1009-E: 125-168.

Curray, J.R., 1956. The analysis of two-dimensional orientation data. J. Geol., 64: 117-131.

Davis, J.D., 1977. Dinosaur Canyon Member of the Triassic Moenave Formation of southwest Utah. In: E.L. Heisey, E.R. Norwood and P.H. Wach (Editors), Rocky Mountain Thrust Belt, Geology and Resources. Wyo. Geol. Assoc. Guidebook, 29th Annual Field Conf., pp. 201-206.

Desmond, R.J., Steidtmann, J.R. and Cardinal, D.F., 1984. Stratigraphy and depositional environments of the middle member of the Minnelusa Formation, central Powder River basin, Wyoming. In: J. Goolsby and D. Morton (Editors), The Permian and Pennsylvanian Geology of Wyoming. Wyo. Geol. Assoc. Guidebook, 35th Annual Field Conf., pp. 213-239.

DeVoto, R.H., 1980. Pennsylvanian stratigraphy and history of Colorado. In: H.C. Kent and K.W. Porter (Editors), Colorado Geology. Rocky Mountain Assoc. Geol., Denver, Colo., pp. 71-101.

Dickinson, W.R., Klute, M.A. and Swift, P.N., 1986. The Bisbee basin and its bearing on Late Mesozoic paleogeographic and paleotectonic relations between the Cordilleran and Caribbean regions. In: P.L. Abbott (Editor), Cretaceous Stratigraphy, Western North America. Pacific Sect., Soc. Econ. Paleontol. Mineral., pp. 51-62.

Dinkins Jr., T.H., 1968. Jurassic stratigraphy of central and southern Mississippi. Miss. Geol., Econ., Topogr. Surv. Bull., 109: 9-37.

Doe, T.W., 1973. Deformed crossbedding from the Weber Formation (Pennsylvanian-Permian), northeast Utah and northwest Colorado. M.S. Thesis, Univ. of Wisconsin, Madison, Wisc., 87 pp. (unpublished).

Doelger, N.M. and Steidtmann, J.R., 1985. Depositional environments of the Nugget Sandstone, Red Canyon Rim, Fremont County, Wyoming. Wyo. Contrib. Geol., 23: 1-23.

Dott Jr., R.H., Byers, C.W., Fielder, G.W., Stenzel, S.R. and Winfree, K.E., 1986. Aeolian to marine transition in Cambro-Ordovician cratonic sheet sandstones of the northern Mississippi Valley. Sedimentology, 33: 345-367.

Driese, S.G. and Dott Jr., R.H., 1984. Model for sandstone-carbonate "cyclothems" based on upper member of Morgan Formation (Middle Pennsylvanian) of northern Utah and Colorado. Bull. Am. Assoc. Pet. Geol., 68: 574-597.

Dubiel, R.F., 1984. Evidence for wet paleoenvironments, Upper Triassic Chinle Formation, Utah. Geol. Soc. Am., Abstr. with Programs, 16: p. 220.

Dubiel, R.F., 1987a. Sedimentology of the Upper Triassic 
Chinle Formation, southeastern Utah. Ph.D. diss., Univ. of Colorado, Boulder, Colo., 130 pp. (unpublished).

Dubiel, R.F., 1987b. Sedimentology and new fossil occurrences of the Upper Triassic Chinle Formation, southeastern Utah. In: J.C. Campbell (Editor), Geology of Cataract Canyon and Vicinity. Four Corners Geol. Soc. Guidebook, 10th Field Conf., pp. 99-107.

Dubiel, R.F., 1987c. Lungfish burrows in the Upper Triassic Chinle and Dolores Formations, Colorado Plateau. J. Sediment. Petrol., 57: 512-521.

Dunne, G.C., Gulliver, R.M. and Sylvester, A.G., 1978. Mesozoic evolution of rocks of the White, Inyo, Argus and Slate Ranges, eastern California. In: D.G. Howell and K.A. McDougall (Editors), Mesozoic Paleogeography of the Western United States. Pacific Coast Sect., Soc. Econ. Paleontol. Mineral., pp. 189-207.

Edwards, D.P., 1985. Controls on deposition of an ancient fluvial/eolian depositional system-the Early Jurassic Moenave Formation of north-central Arizona. M.S. Thesis, Northern Arizona Univ., Flagstaff, Ariz., 243 pp. (unpublished).

Enos, P., 1983. Late Mesozoic paleogeography of Mexico. In: M.W. Reynolds and E.D. Dolly (Editors), Mesozoic Paleogeography of the West-Central United States. Rocky Mountain Sect., Soc. Econ. Paleontol. Mineral., pp. 133-157.

Ferguson, H.G. and Muller, S.W., 1949. Structural geology of the Hawthorne and Tonopah quadrangles, Nevada. U.S. Geol. Surv., Prof. Pap., 216: 55 pp.

Finch, W.I. and Wright, J.C., 1983. Measured stratigraphic sections of uranium-bearing Upper Triassic rocks of the Dockum basin, eastern New Mexico, west Texas, and the Oklahoma panhandle with a brief discussion of stratigraphic problems. U.S. Geol. Surv., Open-File Rep., 83-701: 118 pp.

Fiske, R.S. and Tobisch, O.T., 1978. Paleogeographic significance of volcanic rocks of the Ritter Range pendant, central Sierra Nevada, California. In: D.G. Howell and K.A. McDougall (Editors), Mesozoic Paleogeography of the Western United States. Pacific Coast Sect., Soc. Econ. Paleontol. Mineral., pp. 209-221.

Fly III, S.H., 1986. Depositional environments of the Laborcita Formation (Wolfcampian), northern Sacramento Mountains, New Mexico. In: J.L. Ahlen and M.E. Hanson (Editors), Southwest Section of AAPG, Transactions and Guidebook of 1986 Convention, Ruidoso, New Mexico. N. Mex. Bur. Mines Miner. Resour., pp. 91-96.

Freeman, V.L. and Bryant, B., 1977. Red bed formations in the Aspen region, Colorado. In; H.K. Veal (Editor), Exploration Frontiers of the Central and Southern Rockies. Rocky Mountain Assoc. Geol., Denver, Colo., pp. 181-189.

Fryberger, S.G., 1979. Eolian-fluviatile (continental) origin of ancient stratigraphic trap for petroleum in Weber Sandstone, Rangely oil field, Colorado. Mount. Geol., 16: 1-36.

Fryberger, S.G., 1984. The Permian upper Minnelusa Formation, Wyoming-ancient example of an offshore-prograd- ing eolian sand sea with geomorphic facies, and systemboundary traps for petroleum. In: J. Goolsby and D. Morton (Editors), The Permian and Pennsylvanian Geology of Wyoming. Wyo. Geol. Assoc. Guidebook, 35th Annual Field Conf., pp. 241-271.

Fryberger, S.G. and Koelmel, M.H., 1986, Rangely field--eolian system-boundary trap in the Permo-Pennsylvanian Weber Sandstone of northwest Colorado. In: D.S. Stone (Editor), New Interpretations of Northwest Colorado Geology. Rocky Mount. Assoc. Geol., Denver, Colo., pp. 129-149.

Gottesfeld, A.S., 1972. Paleoecology of the lower part of the Chinle Formation in the Petrified Forest. In: C.S. Breed and W.J. Breed (Editors), Investigations in the Triassic Chinle Formation. Mus. North. Ariz. Bull., 147: 59-74.

Gries, R.R., 1985. San Juan sag-Cretaceous rocks in a volcanic-covered basin, south-central Colorado. Mount. Geol., 22: 167-179.

Hallam, A., 1975. Jurassic Environments. Cambridge Univ. Press, Cambridge, 269 pp.

Hallgarth, W.E., 1967. Environment of western Colorado and southern Utah-interval A. In: E.D. McKee et al. (Editors), Paleotectonic Maps of the Permian System. U.S. Geol. Surv., Misc. Geol. Invest. Map, I-450: 54-56.

Hamilton, W., 1982. Structural evolution of the Big Maria Mountains, northeastern Riverside County, southeastern California. In: E.G. Frost and D.L. Martin (Editors), Mesozoic-Cenozoic Tectonic Evolution of the Colorado River Region, California. Arizona, and Nevada. Cordilleran Publishers, San Diego, Calif,, pp. 1-27.

Hamilton, W., 1987. Mesozoic geology and tectonics of the Big Maria Mountains region, southeastern California. Ariz. Geol. Soc. Digest, 19: 33-47.

Handford, C.R. and Dutton, S.P., 1980. Pennsylvanian-Early Permian depositional systems and shelf-margin evolution, Palo Duro basin, Texas. Bull. Am. Assoc. Pet. Geol., 64: $88-106$.

Hanford, C.R. and Fredericks, P.E., 1980. Facies patterns and depositional history of a Permian sabkha complex-Red Cave Formation, Texas panhandle. Bur. Econ. Geol., Univ. Texas at Austin, Geol. Circ., 80-9: 38 pp.

Heckel, P.H., 1980. Paleogeography of eustatic model for deposition of Midcontinent Upper Pennsylvanian cyclothems. In: T.D. Fouch and E.R. Magathan (Editors), Paleozoic Paleogeography of the West-Central United States. Rocky Mountain Sect., Soc. Econ. Paleontol. Mineral., pp. 197-215.

Hileman, M.E., 1973. Stratigraphy and paleoenvironmental analysis of the Upper Jurassic Preuss and Stump Formations, western Wyoming and southeastern Idaho. Ph.D. diss., Univ, of Michigan, Lansing, Mich., 203 pp. (unpublished).

Hilpert, L.S., 1969. Uranium resources of northwestern New Mexico. U.S. Geol. Surv., Prof. Pap., 603: 166 pp.

Hite, R.J. and Cater, F.W., 1972. Pennsylvanian rocks and salt anticlines, Paradox basin, Utah and Colorado. In: W.W. 
Mallory (Editor), Geologic Atlas of the Rocky Mountain Region. Rocky Mountain Assoc. Geol., Denver, Colo., pp. 133-138.

Honda, H. and McBride, E.F., 1981. Diagenesis and pore types of the Norphlet Sandstone (Upper Jurassic), Hatters Pond area, Mobile County, Alabama. Trans. Gulf Coast Assoc. Geol. Soc., 31: 315-322.

Houlik Jr., C.W., 1973. Interpretation of carbonate-detrital silicate transitions in the Carboniferous of western Wyoming. Bull. Am. Assoc. Pet. Geol., 57: 498-509.

Hubert, J.F. and Mertz, K.A., 1980. Eolian dune field of Late Triassic age, Fundy Basin, Nova Scotia. Geology, 8: 516-519.

Hunt, A., 1983. Plant fossils and lithostratigraphy of the Abo Formation (Lower Permian) in the Socorro area and plant biostratigraphy of Abo red beds in New Mexico. In: C.E. Chapin (Editor), Socorro Region III. N.M. Geol. Soc. Guidebook, 34th Annual Field Conf., pp. 157-163.

Imlay, R.W., 1964. Marine Jurassic pelecypods from central and southern Utah. U.S. Geol. Surv., Prof. Pap., 483-C: $\mathrm{C} 1-\mathrm{C} 42$.

Imlay, R.W., 1967. Twin Creek Limestone (Jurassic) in the Western Interior of the United States. U.S. Geol. Surv., Prof. Pap., 540: 105 pp.

Imlay, R.W., 1980. Jurassic paleobiogeography of the conterminous United States in its continental setting. U.S. Geol. Surv., Prof. Pap., 1062: 134 pp.

Johanson, S.J., 1981. Depositional environments of the Queantoweap Sandstone of northwestern Arizona and southern Nevada. Ph.D. diss., Univ. of Arizona, Tucson, Ariz., 213 pp. (unpublished).

Johnson, S.Y., 1987a. Sedimentology and paleogeography of eolian deposits in the Maroon Formation (Pennsylvanian and Permian), Eagle basin, northwest Colorado. Geol. Soc. Am., Abstr. with Programs, 19: p. 285.

Johnson, S.Y., 1987b. Stratigraphic and sedimentologic studies of late Paleozoic strata in the Eagle basin and northern Aspen sub-basin. U.S. Geol. Surv., Open-File Rep., 87-286: $82 \mathrm{pp}$.

Johnston, I.M., 1975. A detailed stratigraphic and environmental analysis of the San Rafael Group (Jurassic) between Black Mesa, Arizona, and the southern Kaiparowits Plateau, Utah. Ph.D. diss., Univ. of Arizona, Tucson, Ariz., 510 pp. (unpublished).

Jordan, T.E. and Douglas, R.C., 1980. Paleogeography and structural development of the Late Pennsylvanian to Early Permian Oquirrh basin, northwestern Utah. In: T.D. Fouch and E.R. Magathan (Editors), Paleozoic Paleogeography of the West-Central United States. Rocky Mountain Sect., Soc. Econ. Paleontol. Mineral., pp. 217-238.

Jordan, W.M., 1965. Regional environmental study of the early Mesozoic Nugget and Navajo Sandstones. Ph.D. diss., Univ. of Wisconsin, Madison, Wisc., 206 pp. (unpublished).

Kelley, V.C., 1971. Geology of the Pecos country, southeastern New Mexico. N.M. Inst. Min. Tech. Mem., 24: 75 pp.

Kerr, D.R. and Dott Jr., R.H., 1988. Eolian dune types pre- served in the Tensleep Sandstone (Pennsylvanian-Permian), north-central Wyoming. In: G. Kocurek (Editor), Late Paleozoic and Mesozoic Eolian Deposits of the Western Interior of the United States. Sediment. Geol., 56: 383-402 (this volume).

Kistler, R.W., 1974. Phanerozoic batholiths in western North America-a summary of some recent work on variations in time, space, chemistry, and isotopic compositions. In: F.A. Donath, F.G. Stehli and G.W. Wetherill (Editors), Annual Review of Earth and Planetary Sciences. Annual Reviews, Palo Alto, Calif., 2: 403-418.

Kluth, C.F., 1983. Geology of the northern Canelo Hills and implications for the Mesozoic tectonics of southeastern Arizona. In: M.W. Reynolds and E.D. Dolly (Editors), Mesozoic Paleogeography of the West-Central United States. Rocky Mountain Sect., Soc. Econ. Paleontol. Mineral., pp. 159-171.

Kocurek, G., 1981. Erg reconstruction-the Entrada Sandstone (Jurassic) of northern Utah and Colorado. Palaeogeogr., Palaeoclimatol., Palaeoecol., 36: 125-153.

Kocurek, G. and Dott Jr., R.H., 1983. Jurassic paleogeography and paleoclimate of the central and southern Rocky Mountains region. In: M.W. Reynolds and E.D. Dolly (Editors), Mesozoic Paleogeography of the West-Central United States. Rocky Mountain Sect., Soc. Econ. Paleontol. Mineral., pp. 101-116.

Kottlowski, F.E., 1975. Stratigraphy of the San Andres Mountains in south-central New Mexico. In: W.R. Seager, R.E. Clemons and J.F. Callender (Editors), Guidebook of the Las Cruces Country. N. M. Geol. Soc., 26th Annual Field Conf., pp. 95-104.

Kottlowski, F.E., 1985. Shoreline facies of the Yeso Formation in the northern Pedernal Hills. In: S.G. Lucas (Editor), Santa Rosa-Tucumcari Region. N. M. Geol. Soc., Guidebook, 36th Annual Field Conf., pp. 167-169.

Kues, B.S. and Kietzke, K.K., 1976. Paleontology and stratigraphy of the Red Tanks Member, Madera Formation (Pennsylvanian) near Lucero Mesa, New Mexico. In: L.A. Woodward and S.A. Northrop (Editors), Tectonics and Mineral Resources of Southwestern North America. N. M. Geol. Soc., Spec. Publ., 6: 102-108.

Larson, T.C., 1975. Geological considerations of the Weber Sandstone reservoir, Rangely field, Colorado. In: D.W. Bolyard (Editor), Deep Drilling Frontiers of the Central Rocky Mountains. Rocky Mount. Assoc. Geol., pp. 275-279.

Leveille, G. and Frost, E.G., 1984. Deformed upper Paleozoic-lower Mesozoic cratonic strata, El Capitan, Sonora, Mexico. Geol. Soc. Am., Abstr. with Programs, 16: p. 575 .

Lindquist, S.J., 1983. Nugget Formation reservoir characteristics affecting production in the overthrust belt of southwestern Wyoming. J. Pet. Technol., 35: 1355-1365.

Lindquist, S.J., 1988. Practical characterization of eolian reservoirs for development: Nugget Sandstone, Utah-Wyoming Thrust Belt. In: G. Kocurek (Editor), Late Paleozoic 
and Mesozoic Eolian Deposits of the Western Interior of the United States. Sediment. Geol., 56: 315-339 (this volume).

Loope, D.B., 1981. Deposition, deflation, and diagenesis of upper Paleozoic eolian sediments, Canyonlands National Park, Utah. Ph.D. diss., Univ. of Wyoming, Laramie, Wyo., 170 pp. (unpublished).

Loope, D.B., 1984. Eolian origin of upper Paleozoic sandstones, southeastern Utah. J. Sediment. Petrol., 54: 563-580.

Lupe, R. and Ahlbrandt, T.S., 1979. Sediments of the ancient eolian environment-reservoir inhomogeneity. In: E.D. McKee (Editor), A Study of Global Sand Seas. U.S. Geol. Surv., Prof. Pap., 1052: 241-251.

Mack, G.H., 1977. Depositional environments of the Cutler-Cedar Mesa facies transition (Permian) near Moab, Utah. Mount. Geol., 14: 53-68.

Mack, G.H. and James, W.C., 1986. Cyclic sedimentation in the mixed siliciclastic-carbonate Abo-Hueco transitional zone (Lower Permian), southwestern New Mexico. J. Sediment. Petrol., 56: 635-647.

Mallory, W.W., 1972. Pennsylvanian arkose and the ancestral Rocky Mountains. In: W.W. Mallory (Editor), Geologic Atlas of the Rocky Mountain Region, U.S.A. Rocky Mount. Assoc. Geol., Denver, Colo., pp. 131-132.

Mancini, E.A., Mink, R.M., Bearden, B.L. and Wilkerson, R.P., 1985. Norphlet Formation (Upper Jurassic) of southwestern and offshore Alabama-environments of deposition and petroleum geology. Bull. Am. Assoc. Pet. Geol., 69: 881-898.

Marzolf, J.E., 1983a. Early Mesozoic eolian transition from cratonal margin to orogenic-volcanic arc. In: K.D. Gurgel (Editor), Geologic Excursions in Stratigraphy and Tectonics-from Southeastern Idaho to Southern Inyo Mountains, California, via Canyonlands and Arches National Parks, Utah. Utah Geol. Miner. Surv., Spec. Stud., 60: 39-46.

Marzolf, J.E., 1983b. Changing wind and hydrologic regimes during deposition of the Navajo and Aztec Sandstones, Jurassic(?), southwestern U.S. In: M.E. Brookfield and T.S. Ahlbrandt (Editors), Eolian Sediments and Processes. (Developments in Sedimentology, 38) Elsevier, Amsterdam, pp. 635-660.

Marzolf, J.E., 1988. Controls on late Paleozoic and early Mesozoic eolian deposition of the western United States. In: G. Kocurek (Editor), Late Paleozoic and Mesozoic Eolian Deposits of the Western Interior of the United States. Sediment. Geol, 56: 167-191 (this volume).

Maughan, E.K., 1966. Environment of deposition of Permian salt in the Williston and Alliance basins. In: J.L. Rau (Editor), Second Symposium on Salt. North. Ohio Geol. Soc., pp. 35-47.

Maughan, E.K., 1975. Montana, North, Dakota, northeastern Wyoming, and northern South Dakota. In: E.D. McKee and E.J. Crosby (Coordinators), Paleotectonic Investigations of the Pennsylvanian System in the United States, Part 1, Introduction and Regional Analyses of the Penn- sylvanian System. U.S. Geol. Surv., Prof. Pap., 853-0: 279-293.

Maxwell, C.H., 1982. Mesozoic stratigraphy of the LagunaGrants region. In: J.A. Gramling and S.G. Wells (Editors), Albuquerque Country II. N. M. Geol. Soc., 33rd Annual Field Conf., pp. 261-266.

May, S.R. and Butler, R.F., 1986. North American Jurassic apparent polar wander-implications for plate motion, paleogeography and Cordilleran tectonics. J. Geophys. Res., 91: 11, 519-11, 544.

McBride, E.F., 1981. Diagenetic history of Norphlet Formation (Upper Jurassic), Rankin County, Mississippi. Trans. Gulf Coast Assoc. Geol. Soc., 31: 347-351.

McGowen, J.H., Granata, G.E. and Seni, S.J., 1983. Depositional setting of the Triassic Dockum Group, Texas panhandle and eastern New Mexico. In: M.W. Reynolds and E.D. Dolly (Editors), Mesozoic Paleogeography of the West-Central United States. Rocky Mountain Sect., Soc. Econ. Paleontol. Mineral., pp. 13-38.

McKee, E.D., 1982. The Supai Group of Grand Canyon. U.S. Geol. Surv., Prof. Pap., 1173: p. 504.

McKee, E.D., Oriel, S.S., Swanson, V.E., MacLachlan, M.E., MacLachlan, J.C., Ketner, K.B., Goldsmith, J.W., Bell., R.Y. and Jameson, D.J., 1956. Paleotectonic maps of the Jurassic System. U.S. Geol. Surv., Misc. Geol. Invest. Map I-175: 1: 5,000,000.

McKee, E.D., Oriel, S.S., Ketner, K.B., MacLachlan, M.E., Goldsmith, J.W., MacLachlan, J.C. and Mudge, M.R., 1959. Paleotectonic maps of the Triassic System. U.S. Geol. Surv., Misc. Geol. Invest. Map I-300: 1: 5,000,000.

McKee, E.D., Oriel, S.S., Berryhill Jr., H.L., Cheney, T.M., Cressman, E.R., Crosby, E.J., Dixon, G.H., Hallgarth, W.E., Ketner, K.B., MacLachlan, M.E., McKelvey, V.E., Mudge, M.R., Myers, D.A. and Sheldon, R.P., 1967. Paleotectonic maps of the Permian System: U.S. Geol. Surv., Misc. Geol. Invest. Map I-450, 164 pp.

McKee, E.D., Crosby, E.J., Bachman, G.O., Dixon, G.H., Frezon, S.E., Glick, E.E., Irwin, W.P., Mallory, W.W., Mapel, W.J., Maughan, E.K., Prichard, G.E., Shideler, G.L., Stewart, G.F., Wanless, H.R. and Wilson, R.F., 1975. Paleotectonic investigations of the Pennsylvanian System in the United States. U.S. Geol. Surv., Prof. Pap. 853, Pt. I: 349 pp., Pt. II: 192 pp., Pt. III: 17 plates.

McMannis, W.J., 1965. Resume of depositional and structural history of western Montana. Bull. Am. Assoc. Pet. Geol., 49: 1801-1823.

McNair, A.H., 1951. Paleozoic stratigraphy of part of northwestern Arizona. Bull. Am. Assoc. Pet. Geol., 35: 503-541.

Meyer, R.F., 1966. Geology of Pennsylvanian and Wolfcampian rocks in southeast New Mexico. N. M. Bur. Mines Miner. Resour., Mem., 17: 123 pp.

Michaud, D.P., 1987. Depositional history, Upper Jurassic Rierdon Formation, southwestern Montana. Geol. Soc. Am., Abstr. with Programs, 19: p. 321.

Miller, E.L., 1978. The Fairview Valley Formation-a Mesozoic intraorogenic deposit in the southwestern Mojave Des- 
ert. In: D.G. Howell and K.A. McDougall (Editors), Mesozoic Paleogeography of the Western United States. Pacific Coast Sect., Soc. Econ. Paleontol. Mineral., pp. 277-282.

Miller, G.M., 1966. Structure and stratigraphy of southern part of Wah Wah Mountains, southwest Utah. Bull. Am. Assoc. Pet. Geol., 50: 858-900.

Mitchell-Tapping, H.J., 1982. Exploration analysis of the Jurassic Apalachicola embayment of Florida. Trans. Gulf Coast Assoc. Geol. Soc., 32: 413-425.

Moench, R.H. and Schlee, J.S., 1967. Geology and uranium deposits of the Laguna district, New Mexico. U.S. Geol. Surv., Prof. Pap., 519: p. 117.

Nairn, A.E.M., 1961. Descriptive Palaeoclimatology. Interscience, New York, N.Y., 380 pp.

Norwood, E.E., 1965. Geological history of central and southcentral Montana. Bull. Am. Assoc. Pet. Geol., 49: 1824-1832.

Opdyke, N.D. and Runcorn, S.K., 1960. Wind direction in the western United States in the late Paleozoic. Geol. Soc. Am. Bull., 71: 959-972.

O'Sullivan, R.B., 1978. Stratigraphic sections of Middle Jurassic San Rafael Group from Lohali Point, Arizona, to Bluff, Utah. U.S. Geol. Surv., Oil Gas Invest. Chart, OC-77.

O'Sullivan, R.B., 1980. Stratigraphic sections of Middle Jurassic San Rafael Group from Wilson Arch to Bluff in southeastern Utah. U.S. Geol. Surv., Oil Gas Invest. Chart, OC-102.

Otto, E.P. and Picard, M.D., 1975. Stratigraphy and oil and gas potential of Entrada Sandstone (Jurassic), northeastern Utah. In: D.W. Bolyard (Editor), Deep Drilling Frontiers of the Central Rocky Mountains. Rocky Mount. Assoc. Geol., Denver, Colo., pp. 129-139.

Paleogeographic Atlas Project, 1984. Data and Software. Univ. of Chicago, Chicago, I11.

Palmer, A.R., 1983. The Decade of North American Geology 1983 geologic time scale. Geology, 11: 503-504.

Parrish, J.T. and Peterson, F., 1988. Wind directions predicted from global circulation models and wind directions determined from eolian sandstones of the western United States-A comparison. In: G. Kocurek (Editor), Late Paleozoic and Mesozoic Eolian Deposits of the Western Interior of the United States. Sediment. Geol., 56: 261-282 (this volume).

Peterson, F., 1984. Fluvial sedimentation on a quivering craton -influence of slight crustal movements on fluvial processes, Upper Jurassic Morrison Formation, western Colorado Plateau. Sediment. Geol., 38: 21-49.

Peterson, F., 1986. Jurassic paleotectonics in the west-central part of the Colorado Plateau, Utah and Arizona. In: J.A. Peterson (Editor), Paleotectonics and Sedimentation, Rocky Mountain Region, U.S. Mem. Am. Assoc. Pet. Geol., 41: 563-596.

Peterson, F., in press. Stratigraphy and nomenclature of Middle and Upper Jurassic rocks, western Colorado Plateau, Utah and Arizona. U.S. Geol. Surv. Bull., 1633-B.

Peterson, F. and Pipiringos, G.N., 1979. Stratigraphic relations of the Navajo Sandstone to Middle Jurassic formations, southern Utah and northern Arizona. U.S. Geol. Surv., Prof. Pap., 1035-B: B1-B43.

Peterson, F. and Tyler, N., 1985. Field guide to the Upper Salt Wash alluvial complex. In: R.M. Flores and M.D. Harvey (Editors), Field Guidebook to Modern and Ancient Fluvial Systems in the United States. Proc. 3rd Int. Fluvial Sedimentology Conf., Colorado State Univ., Fort Collins, Colo., pp. 45-64.

Peterson, J.A., 1957. Marine Jurassic of northern Rocky Mountains and Williston basin. Bull. Am. Assoc. Pet. Geol., 41: $399-440$.

Peterson, J.A., 1972. Jurassic system. In: W.W. Mallory (Editor), Geologic Atlas of the Rocky Mountain Region, U.S.A. Rocky Mount. Assoc. Geol., pp. 177-189.

Peterson, J.A., 1980. Permian paleogeography and sedimentary provinces, west-central United States. In: T.D. Fouch and E.R. Magathan (Editors), Paleozoic Paleogeography of the West-Central United States. Rocky Mountain Sect., Soc. Econ. Paleontol. Mineral., pp. 271-292.

Peterson, J.A. and Hite, R.J., 1969. Pennsylvanian evaporitecarbonate cycles and their relation to petroleum occurrence, southern Rocky Mountains. Bull. Am. Assoc. Pet. Geol., 53: 884-908.

Phoenix, D.A., 1963. Geology of the Lees Ferry area, Coconino County, Arizona. U.S. Geol. Surv. Bull., 1137: p. 86.

Pipiringos, G.N., 1968. Correlation and nomenclature of some Triassic and Jurassic rocks in south-central Wyoming. U.S. Geol. Surv., Prof. Pap., 594-D: D1-D26.

Pipiringos, G.N. and O'Sullivan, R.B., 1976. Stratigraphic sections of some Triassic and Jurassic rocks from Douglas, Wyoming, to Boulder, Colorado. U.S. Geol. Surv., Oil and Gas Invest. Chart, OC-69.

Pipiringos, G.N. and O'Sullivan, R.B., 1978. Principal unconformities in Triassic and Jurassic rocks, Western Interior U.S. - a preliminary report. U.S. Geol. Surv., Prof. Pap., 1035-A: A1-A29.

Pipiringos, G.N., Hail Jr., W.J. and Izett, G.A., 1969. The Chinle, (Upper Triassic) and Sundance (Upper Jurassic) Formations in north-central Colorado. U.S. Geol. Surv. Bull., 1274-N: N1-N35.

Poole, F.G., 1961. Stream directions in Triassic rocks of the Colorado Plateau. U.S. Geol. Surv., Prof. Pap., 424-C: C139-C141.

Poole, F.G., 1962. Wind directions in late Paleozoic to middle Mesozoic time on the Colorado Plateau. U.S. Geol. Surv., Prof. Pap., 450-D: D147-D151.

Porter, M.L., 1985. Sedimentology and petrology of an Early Jurassic erg margin-Aztec Sandstone, southern Nevada and southern California. Ph.D. diss., Univ. of Wisconsin, Madison, Wisc., 217 pp. (unpublished).

Proffett Jr., J.M. and Dilles, J.H., 1984. Geologic map of the Yerington District, Nevada. Nev. Bur. Mines Geol., Map 77: $1: 24,000$.

Rascoe Jr., B. and Baars, D.L., 1972. Permian System. In: W.W. Mallory (Editor), Geologic Atlas of the Rocky Mountain Region, U.S.A. Rocky Mount. Assoc. Geol., Denver, Colo., pp. 143-165. 
Rautman, C.A., 1978. Sedimentology of Late Jurassic barrierisland complex - lower Sundance Formation of Black Hills. Bull. Am. Assoc. Pet. Geol., 62: 2275-2289.

Rawson, R.R. and Turner, C.E,, 1979. Marine-carbonate, sabkha, and eolian facies transitions within the Permian Toroweap Formation, northern Arizona. In: D.L. Baars (Editor), Permianland. Four Corners Geol. Soc., Guidebook, 9th Field Conf., pp. 87-99.

Read, C.B. and Wanek, A.A., 1961. Stratigraphy of outcropping Permian rocks in parts of northeastern Arizona and adjacent areas. U.S. Geol. Surv., Prof. Pap., 374-H: H1-H10.

Reese, R.S., 1984. Stratigraphy of the Entrada Sandstone and Todilto Limestone (Jurassic), north-central New Mexico. M.S. thesis, Colorado School of Mines, Golden, Colo., No. 2521: 182 pp. (unpublished).

Reiche, P., 1983. An analysis of cross-lamination, the Coconino Sandstone. J. Geol., 46: 905-932.

Reynolds, S.J., 1980. Geologic framework of west-central Arizona. In: J.P. Jenney and C. Stone (Editors), Studies in Western Arizona. Ariz. Geol. Soc. Digest, 12: 1-16.

Rich, M., 1977. Pennsylvanian paleogeographic patterns in the western United States. In: J.H. Stewart, C.H. Stevens and A.E. Fritsche (Editors), Paleozoic Paleogeography of the Western United States. Pacific Coast Sect., Soc. Econ. Paleontol. Mineral., pp. 87-111.

Ridgley, J.L., 1984. Paleogeography and facies distribution of the Todilto Limestone and Pony Express Limestone Member of the Wanakah Formation, Colorado and New Mexico. Geol. Soc. Am., Abstr. with Programs, 16: p. 252.

Rittersbacher, D.J., 1985. Facies relationships of the Tensleep Sandstone and Minnelusa Formation, western Powder River basin, Johnson County, Wyoming. M.S. thesis, Colorado School of Mines, Golden, Colo., No. T-3071: 188 pp. (unpublished).

Rubin, D.M. and Hunter, R.E., 1983. Reconstructing bedform assemblages from compound crossbedding. In: M.E. Brookfield and T.S. Ahlbrandt (Editors), Eolian Sediments and Processes. (Developments in Sedimentology, 38) Elsevier, Amsterdam, pp. 407-427.

Russell, B.J., 1984. Mesozoic geology of the Jackson Mountains, northwestern Nevada. Geol. Soc. Am. Bull., 95: 313-323.

Saleeby, J.B., Goodin, S.E., Sharp, W.D. and Busby, C.J., 1978. Early Mesozoic paleotectonic-paleogeographic reconstruction of the southern Sierra Nevada region. In: D.G. Howell and K.A. McDougall (Editors), Mesozoic Paleogeography of the Western United States. Pacific Coast Sect., Soc. Econ. Paleontol. Mineral,, pp. 311-336.

Salvador, A., 1987. Late Triassic-Jurassic paleogeography and origin of Gulf of Mexico basin. Bull., Am. Assoc. Pet. Geol., 71: 419-451.

Santos, E.S. and Turner-Peterson, C.E., 1986. Tectonic setting of the San Juan basin in the Jurassic. In: C.E. TurnerPeterson, E.S. Santos and N.S. Fishman (Editors), A Basin Analysis Case Study - The Morrison Formation, Grants Uranium Region, New Mexico. Am. Assoc. Pet. Geol, Stud. Geol., 22: 27-33.
Saperstone, H.I. and Ethridge, F.G., 1984. Origin and paleotectonic setting of the Pennsylvanian Quadrant Sandstone, southwest Montana. In: J. Goolsby and D. Morton (Editors), The Permian and Pennsylvanian Geology of Wyoming. Wyo. Geol. Assoc., Guidebook, 35th Annual Field Conf., pp. 309-331.

Sargent, K.A. and Roggensack, K., 1984. Map showing outcrops of granitic rocks, Basin and Range Province, Nevada. U.S. Geol. Surv., WRI Report, 83-4119-D, 1: 500,000.

Schwartzbach, M., 1963. Climates of the Past, an Introduction to paleoclimatology. Van Nostrand, New York, N.Y., 328 pp.

Scotese, C.R., 1979. Phanerozoic continental drift base maps. In: R.K. Bambach and C.R. Scotese (Editors), Paleogeographic Reconstructions, State of the Art. Geol. Soc. Am., Southeastern Sect., Short Course.

Scott, G.R., Taylor, R.B., Epis, R.C. and Wobus, R.A., 1978. Geologic map of the Pueblo $1^{\circ} \times 2^{\circ}$ quadrangle, southcentral Colorado. U.S. Geol. Surv., Misc. Invest. Ser., Map I-1022: 1: 250,000.

Segerstrom, K. and Young, E.J., 1972. General geology of the Hahns Peak and Farwell Mountain quadrangles, Routt County, Colorado. U.S. Geol. Surv. Bull., 1349: 63 pp.

Siemers, W.T., 1983. The Pennsylvanian System, Socorro region, New Mexico-stratigraphy, petrology, depositional environments. In: C.E. Chapin (Editor), Socorro Region II. N.M. Geol. Soc., Guidebook, 34th Annual Field Conf., pp. 147-155.

Silberling, N.J. and Wallace, R.E., 1969. Stratigraphy of the Star Peak Group (Triassic) and overlying lower Mesozoic rocks, Humboldt Range, Nevada. U.S. Geol. Surv., Prof. Pap., 592: 50 pp.

Silberling, N.J., Jones, D.L., Blake Jr., M.C. and Howell, D.G., 1987. Lithotectonic terrane map of the western conterminous United States. U.S. Geol. Surv., Misc. Field Stud. Map MF-1874-C: 1: 2,500,000.

Silver, C., 1948. Jurassic overlap in western New Mexico. Bull. Am. Assoc. Pet. Geol, 32: 68-81.

Silver, L.T. and Anderson, T.H., 1974. Possible left-lateral early to middle Mesozoic disruption of the southwestern North American margin. Geol. Soc. Am., Abstr. with Programs, 6: p. 955 .

Skipp, B. and Hall, W.E., 1980. Upper Paleozoic paleotectonics and paleogeography of Idaho. In: T.D. Fouch and E.R. Magathan (Editors), Paleozoic Paleogeography of the West-Central United States. Rocky Mountain Sect., Soc. Econ. Paleontol. Mineral., pp. 387-422.

Snoparsky, M.B., 1986. Depositional environments and provenance of the Exeter Sandstone of Cimmaron County, Oklahoma, and adjacent parts of Union County, New Mexico. M.S. thesis, Univ. of Tulsa, Tulsa, Okla., 118 pp. (unpublished).

Speed, R.C., 1974. Evaporite-carbonate rocks of the Jurassic Lovelock Formation, West Humboldt Range, Nevada. Geol. Soc. Am. Bull., 85: 105-118.

Speed, R.C., 1978a. Basinal terrane of the early Mesozoic marine province of the western Great Basin. In: D.G. Howell and K.A. McDougall (Editors), Mesozoic 
Paleogeography of the Western United States. Pacific Coast Sect., Soc. Econ. Paleontol. Mineral, pp. 237-252.

Speed, R.C., 1978b. Paleogeographic and plate tectonic evolution of the early Mesozoic marine province of the western Great Basin. In: D.G. Howell and K.A. McDougall (Editors), Mesozoic Paleogeography of the Western United States. Pacific Coast Sect., Soc. Econ. Paleontol. Mineral., pp. 253-270.

Speed, R.C. and Jones, T.A., 1969. Synorogenic quartz sandstone in the Jurassic mobile belt of western Nevada-Boyer Ranch Formation. Geol. Soc. Am. Bull., 80: 2551-2584.

Stanley, K.O., Jordan, W.M. and Dott Jr., R.H., 1971. Early Jurassic paleogeography, western United States. Bull. Am. Assoc. Pet. Geol., 55: 16-19.

Steed, D.A., 1980. Geology of the Virgin River Gorge, northwest Arizona. Brigham Young Univ. Geol. Stud., 27: 96-115.

Steele-Mallory, B.A., 1982. The depositional environment and petrology of the White Rim Sandstone Member of the Permian Cutler Formation, Canyonlands National Park, Utah. U.S. Geol. Surv., Open-File Rep., 82-204: 81 pp.

Stern, T.W., Bateman, P.C., Morgan, B.A., Newell, M.F. and Peck, D.L., 1981. Isotopic U-Pb ages of zircon from the granitoids of the central Sierra Nevada, California. U.S. Geol. Surv., Prof. Pap., 1185: 17 pp.

Stevens, C.H., 1977. Permian depositional provinces and tectonics, western United States. In: J.H. Stewart, C.H. Stevens and A.E. Fritsche (Editors), Paleozoic Paleogeography of the Western United States. Pacific Coast Sect, Soc. Econ. Paleontol. Mineral., pp. 113-135.

Stewart, J.H., Poole, F.G. and Wilson, R.F., 1956. Triassic studies. U.S. Atomic Energy Comm., Trace Element Invest. Rep., TEI-690: 341-351.

Stewart, J.H., Poole, F.G. and Wilson, R.F., 1972. Stratigraphy and origin of the Chinle Formation and related Upper Triassic strata in the Colorado Plateau region. U.S. Geol. Surv., Prof. Pap., 690: 336 pp.

Stewart, J.H., Anderson, T.H., Haxel, G.B., Silver, L.T. and Wright, J.E., 1986. Late Triassic paleogeography of the southern Cordillera-the problem of a source for voluminous volcanic detritus in the Chinle Formation of the Colorado Plateau region. Geology, 14: 567-570.

Stone, P., Howard, K.A. and Hamilton, W., 1983. Correlation of metamorphosed Paleozoic strata of the southeastern Mojave Desert region, California and Arizona. Geol. Soc. Am. Bull., 94: 1135-1147.

Sutherland, P.K., 1972. Pennsylvanian stratigraphy, southern Sangre De Cristo Mountains, New Mexico. In: W.W. Mallory (Editor), Geologic Atlas of the Rocky Mountain Region, U.S.A. Rocky Mount. Assoc. Geol., Denver, Colo., pp. 139-142.

Szigeti, G.J. and Fox, J.E., 1981. Unkpapa Sandstone (Jurassic), Black Hills, South Dakota-an eolian facies of the Morrison Formation. In: F.G. Ethridge and R.M. Flores (Editors), Recent and Ancient Nonmarine Depositional Environments-Models for Exploration. Soc. Econ. Paleontol. Mineral., Spec. Publ., 31: 331-349.
Tanner, W.F., 1965. Upper Jurassic paleogeography of the Four Corners region. J. Sediment. Petrol., 35: 534-574.

Tromp, P.L., Cardinal, D.F. and Steidtmann, J.R., 1981. Stratigraphy and depositional environments of the "Leo sands" in the Minnelusa Formation, Wyoming and South Dakota. In: S.G. Reid and D.D. Mille (Editors), Energy Resources of Wyoming. Wyo. Geol. Assoc. Guidebook, 32rd Annual Field Conf., pp. 11-22.

Tweto, O., 1957. Geologic sketch of southern Middle Park, Colorado. In: W.C. Finch (Editor), Guidebook to the Geology of North and Middle Parks Basin, Colorado. Rocky Mount. Assoc. Geol., pp. 18-31.

Tweto, O., 1976. Geologic map of the Craig $1^{\circ} \times 2^{\circ}$ quadrangle, northwestern Colorado. U.S. Geol. Surv., Misc. Invest. Ser., 1: 250,000.

Tweto, O., 1980. Tectonic history of Colorado. In: H.C. Kent and K.W. Porter (Editors), Colorado Geology. Rocky Mount. Assoc. Geol., pp. 5-9.

Tweto, O., Steven, T.A., Hail Jr., W.J. and Moench, R.H., 1976. Preliminary geologic map of the Montrose $1^{\circ} \times 2^{\circ}$ quadrangle, southwestern Colorado. U.S. Geol. Surv., Misc. Field Stud., Map MF-761: $1: 250,000$.

Tweto, O., Moench, R.H. and Reed Jr., J.C., 1978. Geologic map of the Leadville $1^{\circ} \times 2^{\circ}$ quadrangle, northeastern Colorado. U.S. Geol. Surv., Misc. Invest. Ser., Map I-999: $1: 250,000$.

Uhlir, D.M., 1987. Subtle tectonics in the Late Jurassic Wyoming foreland-distribution of Sundance chert and Morrison eolianites. Geol. Soc. Am., Abstr. with Programs, 19: p. 339.

Ver Hoeve, M.W., 1982. The petrology and reservoir character of the Entrada Sandstone (Jurassic), Durango, Colorado. M.S. thesis, Univ. of Texas, Austin, Tex., 240 pp. (unpublished).

Vincelette, R.R. and Chittum, W.E., 1981. Exploration for oil accumulations in Entrada Sandstone, San Juan basin, New Mexico. Bull. Am. Assoc. Pet. Geol., 65: 2546-2570.

Ward, D.E., 1957. Geology of the Middle Fork of the Michigan River, Jackson County, Colorado. In: W.C. Finch (Editor), Guidebook to the Geology of North and Middle Parks Basin, Colorado. Rocky Mount. Assoc. Geol., pp. 70-73.

Weaver, C.L., 1980. Geology of the Blue Mountain quadrangle - Beaver and Iron Counties, Utah. Brigham Young Univ. Geol. Stud., 27: 116-132.

Weimer, R.J. and Erickson, R.A., 1976. Lyons Formation (Permian), Golden-Morrison area, Colorado. In: R.C. Epis and R.J. Weimer (Editors), Studies in Colorado Geology. Prof. Contrib. Colo. School Mines, 8: 123-138.

Wengerd, S.A. and Matheny, M.L., 1958. Pennsylvanian system of Four Corners region. Bull. Am. Assoc. Pet. Geol. 42: 2048-2106.

Wermund, E.G. and Jenkins Jr., W.A., 1969. Late Pennsylvanian Series in north-central Texas. In: L.F. Brown, Jr. and E.G. Wermund (Editors), Guidebook to the Late Pennsylvanian Shelf Sediments, North-Central Texas. Dallas Geol. Soc., pp. 1-11. 
York, H.F., 1957, Geology of the Elk Mountain anticline, North Park, Colorado. In: W.C. Finch (Editor), Guidebook to the Geology of North and Middle Parks Basin, Colorado. Rocky Mount. Assoc. Geol., pp. 74-81.
Ziegler, A.M., Scotese, C.R. and Barrett, S.F., 1983. Mesozoic and Cenozoic paleogeographic maps. In: P. Brosche and $J$. Sundermann (Editors), Tidal Friction and the Earth's Rotation, II. Springer, Berlin, pp. 240-252. 